\title{
OECD Series on Adverse Outcome Pathways No. 2
}

\section{Adverse Outcome Pathway on Protein Alkylation Leading to Liver Fibrosis}

\section{Brigitte Landesmann}




\section{Foreword}

This Adverse Outcome Pathway (AOP) on protein alkylation leading to liver fibrosis has been developed under the auspices of the OECD AOP Development Programme, overseen by the Extended Advisory Group on Molecular Screening and Toxicogenomics (EAGMST), which is an advisory group under the Working Group of the National Coordinators for the Test Guidelines Programme (WNT). The AOP has been reviewed internally by the EAGMST, externally by experts nominated by the WNT, and has been endorsed by the WNT and the Task Force on hazard Assessment (TFHA) in April 2016.

Through endorsement of this AOP, the WNT and the TFHA express confidence in the scientific review process that the AOP has undergone and accept the recommendation of the EAGMST that the AOP be disseminated publicly. Endorsement does not necessarily indicate that the AOP is now considered a tool for direct regulatory application.

The Joint Meeting of the Chemicals Committee and the Working Party on Chemicals, Pesticides and Biotechnology agreed to declassification of this AOP on 17 June 2016.

This document is being published under the responsibility of the Joint Meeting of the Chemicals Committee and the Working Party on Chemicals, Pesticides and Biotechnology. 


\section{Table of Contents}

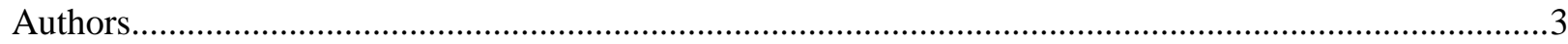

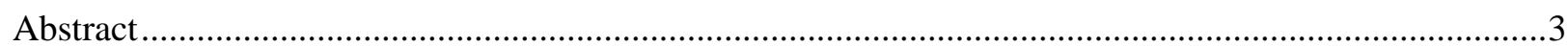

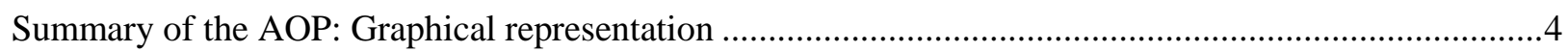

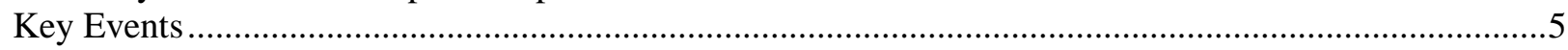

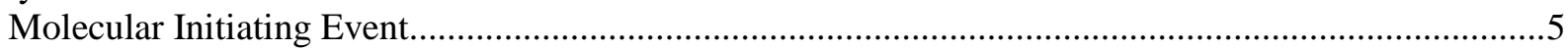

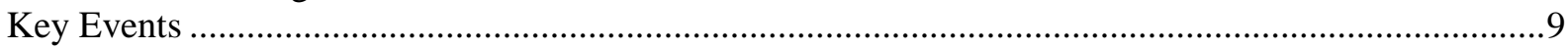

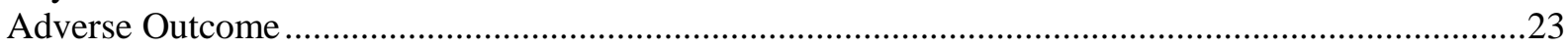

Key Event Relationships: Scientific evidence supporting the linkages in the AOP ...............................26

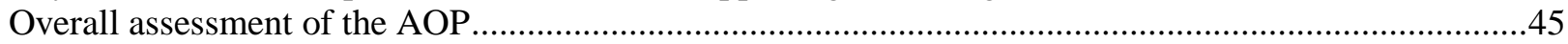

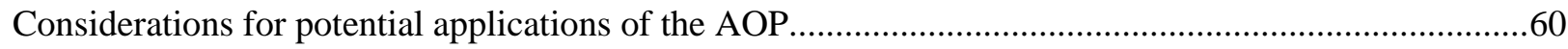

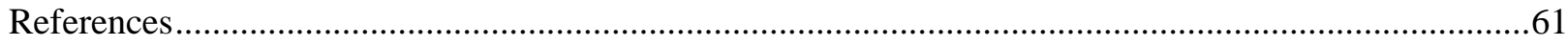




\title{
ADVERSE OUTCOME PATHWAY ON PROTEIN ALKYLATION LEADING TO LIVER FIBROSIS
}

Short name: Protein alkylation to liver fibrosis

\section{Authors}

Brigitte Landesmann

Systems Toxicology Unit and EURL ECVAM, Institute for Health and Consumer Protection European Commission Joint Research Centre,

Brigitte.LANDESMANN@ec.europa.eu

\begin{abstract}
Hepatotoxicity in general is of special interest for human health risk assessment. Liver fibrosis in particular is an important human health issue associated with chemical exposure and predictive assays are lacking; it is a typical result of chronic or repeated-dose toxic injury and one of the considered endpoints for regulatory purposes. It is a long-term process in which inflammation, tissue destruction, and repair occur simultaneously, together with sustained production of growth factors and fibrogenic cytokines due to a complex interplay between various hepatic cell types, various receptors and signalling pathways which lead to an imbalance between the deposition and degradation of extracellular matrix (ECM) and a change of ECM composition. Due to this complex situation an adequate cell model is not available and an in vitro evaluation of fibrogenic potential is therefore not feasible. A sufficiently detailed description of the AOP to liver fibrosis might support chemical risk assessment by indicating early (upstream) markers for downstream events and facilitate a testing strategy without the need for a sophisticated cell model. This systematic and coherent display of currently available mechanistic-toxicological information can serve as a knowledge-based repository for identification/selection/development of in vitro methods suitable for measuring key events (KEs) and their relationships along the AOP and to facilitate the use of alternative data for regulatory purposes. Identified uncertainties and knowledge gaps can direct future research by priority setting and targeted testing. The KE descriptions can be used for hazard identification and read-across to assess the toxic potential of an untested substance.

This AOP describes the linkage between hepatic injury caused by protein alkylation and the formation of liver fibrosis. The molecular initiating event (MIE) is protein alkylation, leading to structural and functional cell injury and further to cell death, the first KE. Apoptotic hepatocytes undergo genomic DNA fragmentation and formation of apoptotic bodies. Upon engulfment of apoptotic bodies Kupffer cells (KCs) are activated, the next KE along the pathway. Activated KCs are the main source of TGF- $\beta 1$, the most potent profibrogenic cytokine. TGF- $\beta 1$ expression therefore is considered a $\mathrm{KE}$ that causes the next KE, hepatic stellate cell (HSCs) activation, meaning the transdifferentiation from a quiescent vitamin A-storing cell to a proliferative and contractile myofibroblast, the central effector in hepatic fibrosis. Activated HSCs cause progressive collagen accumulation, which together with changes in ECM composition signifies the KE on tissue level. The excessive accumulation of extracellular matrix proteins progressively affects the whole organ and alters its normal functioning, which corresponds to liver fibrosis, the adverse outcome (AO).
\end{abstract}


There are two further events that play an important role in driving fibrogenesis, namely oxidative stress and chronic inflammation. Both are on-going processes being present throughout the pathway and interconnected with most of the KEs. Hence, they are not classified as KEs themselves and described in the individual KE and key event relationship (KER) descriptions. The inflammatory response plays an important role in driving fibrogenesis, since persistent inflammation precedes fibrosis. Inflammatory signalling stems from injured hepatocytes, activated KCs and HSCs. Inflammatory and fibrogenic cells stimulate each other in amplifying fibrosis. Chemokines and their receptors provoke further fibrogenesis, as well as interacting with inflammatory cells to modify the immune response during injury. Oxidative stress, as well, plays a crucial role in liver fibrogenesis by inducing hepatocyte apoptosis, activation of KCs and HSCs and fuelling inflammation. ROS contributing to oxidative stress are generated by hepatocytes, KCs, HSCs and inflammatory cells.

This purely qualitative AOP description is plausible, the scientific data supporting the AOP are logic, coherent and consistent and there is temporal agreement between the individual KEs. Quantitative data on dose-response-relationships and temporal sequences between KEs are still lacking; the provision of quantitative data will further strengthen the weight of evidence and make the AOP applicable for a wide range of purposes.

\section{Summary of the AOP: Graphical representation}

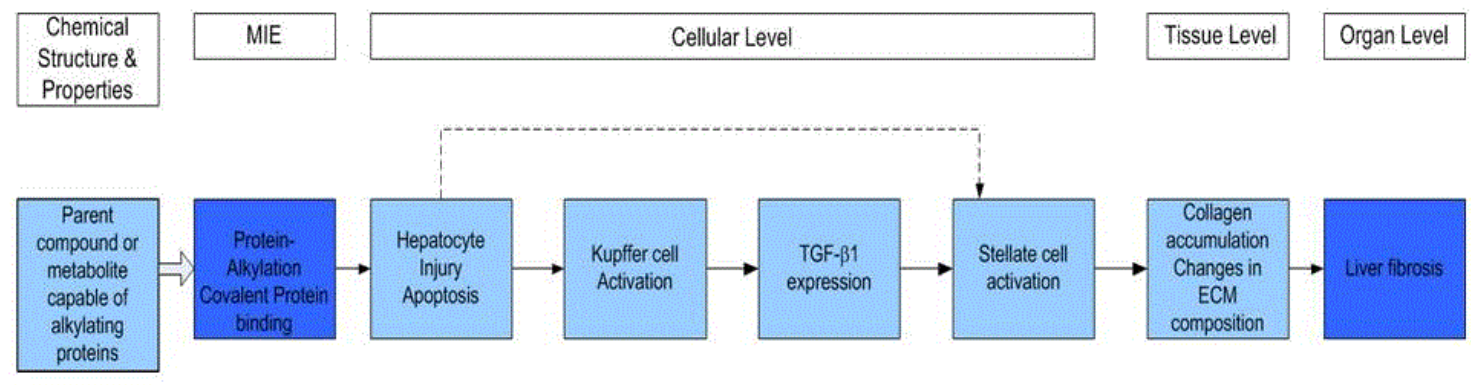




\section{Key Events}

Molecular Initiating Event

Molecular Initiating Event

Protein, Alkylation

Protein, alkylation

AOPs including this Key Event

\begin{tabular}{|l|l|l|}
\hline \multicolumn{1}{|c|}{ AOP name } & Event type & Essentiality \\
\hline Protein alkylation leading to liver fibrosis & MIE & Strong \\
\hline
\end{tabular}

\section{Chemical initiators}

The following are chemical initiators that operate directly through this Event:

1. Allyl Alcohol

2. Carbon tetrachloride

3. Retinol

4. Dimethyl nitrosamine

5. Thioacetamide

How this Key Event works

Level of biological organisation

Molecular

Alkylation is the transfer of an alkyl group from one molecule to another. The alkyl group may be transferred as an alkyl carbocation, a free radical, a carbanion or a carbene (or their equivalents). Protein alkylation is the addition of an alkyl group to a protein amino acid. An alkyl group is any group derived from an alkane by removal of one hydrogen atom. Alkylating agents are highly reactive chemicals that introduce alkyl groups into biologically active molecules and thereby prevent their proper functioning. Alkylating agents are classified according to their nucleophilic or electrophilic character. Nucleophilic alkylating agents deliver the equivalent of an alkyl anion (carbanion). These compounds typically can add to an electron-deficient carbon atom such as at a carbonyl group. Electrophilic alkylating agents deliver the equivalent of an alkyl cation. Alkyl halides can also react directly with amines to form $\mathrm{C}-\mathrm{N}$ bonds; the same holds true for other nucleophiles such as alcohols, carboxylic acids, thiols, etc. Alkylation with only one carbon is termed methylation (EBI; Livertox; NLM).

Covalent protein alkylation by reactive electrophiles was identified as a key triggering event in chemical toxicity over 40 years ago and these reactions remain a major cause of chemical-induced 
toxicity. Interestingly, some chemical molecules produce significant protein covalent binding without causing toxicity, which suggests that only a critical subset of protein alkylation events contributes to injury. The study by Codreanu et al. (2014) describes an inventory of electrophilemediated protein damage in intact cells and suggests that non-toxic covalent binding may largely be survivable damage to cytoskeletal components, whereas toxic covalent binding produces lethal injury by targeting protein synthesis and catabolism and possibly mitochondrial electron transport (Codreanu et al., 2014; Grattigliano et al., 2009; Kehrer and Biswal, 2000; Livertox/alkylating agents; Schopfer et al., 2011).

\section{How it is measured or detected}

HPLC-ESI-MS/MS analysis

High Performance Liquid Chromatography - electrospray tandem mass spectrometry (HPLC-ESIMS/MS) is the most popular MS technique. It combines the separation ability of HPLC along with the sensitivity and specificity of detection from MS. One of the advantages of HPLC-MS is that it allows samples to be rapidly desalted online, so no sample preparation is required unlike samples for GC-MS. Electrospray ionisation can produce singly or multiply charged ions. Typically high molecular weight compounds have multiple charges i.e. peptides and proteins. This technique is particularly suited to analysing polar molecules of mass <2000 Dalton and requires no prior derivatisation in most applications (Codreanu et al., 2014; Gundry et al., 2009; Zhang et al., 2005).

MALDI-TOF/MS (Matrix Assisted Laser Desorption/Ionisation Time of Flight Mass Spectrometry)

Matrix-assisted laser desorption/ionisation (MALDI) is a soft ionisation technique used in mass spectrometry, allowing the analysis of biomolecules (biopolymers such as DNA, proteins, peptides and sugars) and large organic molecules (such as polymers, dendrimers and other macromolecules), which tend to be fragile and fragment when ionised by more conventional ionisation methods. MALDI methodology is a three-step process. First, the sample is mixed with a suitable matrix material and applied to a metal plate. Second, a pulsed laser irradiates the sample, triggering ablation and desorption of the sample and matrix material. Finally, the analyte molecules are ionised by being protonated or deprotonated in the hot plume of ablated gases, and can then be accelerated into whichever mass spectrometer is used to analyse them (Kislinger et al., 2005). cite_note-10

Evidence supporting taxonomic applicability

\begin{tabular}{|l|l|l|l|}
\hline \multicolumn{1}{|c|}{ Name } & Scientific name & Evidence & Links \\
\hline human & Homo sapiens & Strong & NCBI \\
\hline Rattus norvegicus & Rattus norvegicus & Strong & NCBI \\
\hline mouse & Mus musculus & Strong & NCBI \\
\hline
\end{tabular}

Human, rat, mouse: EPA, 2010. 
Two prototypical chemicals acting via protein alkylation are Allyl Alcohol (Auerbach et al., 2008; Huang et al., 2008; Kehrer and Biswal, 2000; Mohammad et al., 2012; Yamada et al., 2013) and Carbon Tetrachloride $\left(\mathrm{CCl}_{4}\right)$ (Basu, 2003; Calabrese et al., 1993; Clawson,1989; EPA, 2010; Knockaert et al., 2012; Lee et al., 2004; Li et al., 2013; Manibusan et al., 2007; Masuda, 2006; Nagano et al., 2007; Recknagel, 1976; Weber et al., 2003).

Covalent protein alkylation is a feature of many cytotoxic drugs but the overall extent of binding does not adequately distinguish toxic from non-toxic binding (Bauman et al., 2009). Interestingly, some chemicals significantly alkylate proteins without causing toxicity, which suggests that only alkylation of a specific protein critical subset contributes to injury. Indeed, Codreanu (2014) presented an inventory of proteins affected by electrophile-mediated alkylation in intact cells and suggested that non-toxic covalent binding largely affects cytoskeletal protein components, whereas toxic covalent binding induces lethal injury by targeting factors involved in protein synthesis and catabolism and possibly mitochondrial electron transport. In vitro covalent binding studies to macromolecules have been used to elucidate the biochemical mechanisms of chemicalinduced toxicity. Experimental work with kidney epithelial cells by Chen et al. (1990) suggested that following alkylation of cellular macromolecules as initial cytotoxic event both sulfhydryl depletion and lipid peroxidation are components of the cytotoxic mechanism. Dennehy et al. (2006) have analysed the protein targets in nuclear and cytoplasmic proteomes from human embryonic kidney cells (HEK293) treated in vitro with two biotin-tagged, thiol-reactive electrophiles and mapped the adducts. Certain protein families appeared particularly susceptible to alkylation. Shin et al. (2007) have identified protein targets of two biotin-tagged model electrophiles in human liver microsomes through LC-MS-MS and showed that different target selectivities of the two electrophile probes correlated with different biological outcomes and that alkylation reactions of specific targets could be quantified.

\section{References}

Auerbach, S.S. et al. (2008), A comparative 90 day toxicity study of allyl acetate, allyl alcohol and acrolein, Toxicology, Vol. 253, No.1-3, pp.79-88.

Basu, S. (2003), Carbon tetrachloride-induced lipid peroxidation: eicosanoid formation and their regulation by antioxidant nutrients, Toxicology, vol.189, no.1-2, pp. 113-127.

Bauman, J.N. et al. (2009), Can in vitro metabolism-dependent covalent binding data distinguish hepatotoxic from nonhepatotoxic drugs? An analysis using human hepatocytes and liver S-9 fraction, Chem Res Toxicol, vol. 22, no.2, pp. 332-340.

Calabrese, E.J., L.A. Baldwin and H.M. Mehendale (1993), G2 subpopulation in rat liver induced into mitosis by low-level exposure to carbon tetrachloride: an adaptive response, Toxicol Appl Pharmacol, vol. 121. no. 1, pp. 1-7.

Chen, Q. et al. (1990), The mechanism of cysteine conjugate cytotoxicity in renal epithelial cells. Covalent binding leads to thiol depletion and lipid peroxidation, J Biol Chem, vol. 265, no. 35, pp. 2160321611.

Clawson, G.A. (1989), Mechanisms of carbon tetrachloride hepatotoxicity, Pathol Immunopathol Res, vol. 8, no. 2, pp.104-112. 
Codreanu, S.G. et al. (2014), Alkylation damage by lipid electrophiles targets functional protein systems, Molecular \& Cellular Proteomics, vol. 13, no. 3, pp.849-859.

Dennehy, M.K. et al. (2006), Cytosolic and nuclear protein targets of thiol-reactive electrophiles, Chem Res Toxicol, vol. 19, no. 1, pp. 20-29.

EBI, The European Bioinformatics Institute www.ebi.ac.uk/QuickGO/GTerm?id=GO:0008213 (accessed on 20 January 2016).

EPA, (2010), Toxicological review of Carbon Tetrachloride (CAS No. 56-23-5), US Environmnetal Protection Agency, EPA/635/R-08/005F http://cfpub.epa.gov/ncea/iris/iris_documents/documents/toxreviews/0020tr.pdf (accessed on 24 October 2015)

Grattagliano, I. et al. (2009), Biochemical mechanisms in drug-induced liver injury: certainties and doubts, World J Gastroenterol, vol. 15, no. 39, pp. 4865-4876.

Gundry, R.L. et al. (2009), Preparation of proteins and peptides for mass spectrometry analysis in a bottom-up proteomics workflow, Curr Protoc Mol Biol, chapter 10, section VI, unit 10.25, pp. 1-23.

Huang, L. et al. (2008), Genes related to apoptosis predict necrosis of the liver as a phenotype observed in rats exposed to a compendium of hepatotoxicants, BMC Genomics, vol. 9: 288.

Kehrer, J.P. and S. Biswal (2000), The Molecular Effects of Acrolein, Toxicol. Sciences, vol. 57, no. 1, pp. 6-15.

Kislinger, T. et al. (2005), Analysis of protein glycation products by MALDI-TOF/MS, Ann N Y Acad Sci, vol. 1043, pp. 249-259.

Knockaert, L. et al. (2012), Carbon tetrachloride-mediated lipid peroxidation induces early mitochondrial alterations in mouse liver, Lab Invest, vol. 92, no. 3, pp. 396-410.

Lee Kwang-Jong et al. (2004), Induction of molecular chaperones in carbon tetrachloride-treated rat liver: implications in protection against liver damage, Cell Stress Chaperones, vol. 9, no. 1, pp. 58-68.

$\mathrm{Li}$, Xiaowei et al. (2014), NMR-based metabonomic and quantitative real-time PCR in the profiling of metabolic changes in carbon tetrachloride-induced rat liver injury, J Pharm Biomed Anal; vol. 89, pp. $42-49$.

Livertox http://livertox.nlm.nih.gov/AlkylatingAgents.htm (accessed on 20 January 2016).

Manibusan, M.K., M. Odin and D.A. Eastmond (2007), Postulated carbon tetrachloride mode of action: a review, J Environ Sci Health C Environ Carcinog Ecotoxicol Rev, vol. 25, no. 3, pp.185-209.

Masuda, Y. (2006), [Learning toxicology from carbon tetrachloride-induced hepatotoxicity], Yakugaku Zasshi, vol. 126, no. 10, pp. 885-899.

Mohammad, M.K. et al. (2012), Acrolein cytotoxicity in hepatocytes involves endoplasmic reticulum stress, mitochondrial dysfunction and oxidative stress, Toxicol Appl Pharmacol, vol. 265, no. 1, pp. 73-82.

Nagano, K. et al. (2007), Inhalation carcinogenicity and chronic toxicity of carbon tetrachloride in rats and mice, Inhal Toxicol, vol 19, no. 13, pp. 1089-1103.

NLM, Medical Subject Headings, National Library of Medicine, www.nlm.nih.gov/cgi/mesh/2011/MB_cgi?mode=\&term=Alkylating+agents $\quad$ (accessed on 20 January 2016).

Recknagel, R.O. (1976), Carbon tetrachloride hepatotoxicity, Pharmacol Rev, vol. 19, no. 2, pp. 145-208.

Schopfer, F.J., C. Cipollina and B.A. Freeman (2011), Formation and Signaling Actions of Electrophilic Lipids, Chem Rev, vol. 111, no. 10, pp. 5997-6021.

Shin, N.Y. et al. (2007), Protein targets of reactive electrophiles in human liver microsomes, Chem Res Toxicol, vol. 20, no. 6, pp. 859-867. 
Weber, L.W., M. Boll and A. Stampfl (2003), Hepatotoxicity and mechanism of action of haloalkanes: carbon tetrachloride as a toxicological model, Crit Rev Toxicol, vol. 33, no. 2, pp. 105-136.

Yamada T et al., (2013), A category approach to predicting the repeated-dose hepatotoxicity of allyl esters, Regulatory Toxicology and Pharmacology, vol. 65, no. 2, pp. 189-195.

Zhang $\mathrm{F}$ et al. (2005), Differential adduction of proteins vs. deoxynucleosides by methyl methanesulfonate and 1-methyl-1-nitrosourea in vitro, Mass Spectrom, vol 19, no.4, pp. 438-448.

Key Events

\begin{tabular}{|l|}
\hline \multicolumn{1}{|c|}{ Key Event } \\
\hline Cell death, N/A \\
\hline Hepatic macrophages (Kupffer Cells), Activation \\
\hline TGFbeta1 expression, Up Regulation \\
\hline Stellate cells, Activation \\
\hline Collagen, Accumulation \\
\hline
\end{tabular}

\section{Cell injury/death, N/A}

AOPs including this Key Event

\begin{tabular}{|c|c|c|}
\hline AOP name & $\begin{array}{c}\text { Event } \\
\text { type }\end{array}$ & Essentiality \\
\hline $\begin{array}{l}\text { Binding of agonists to ionotropic glutamate receptors in adult brain causes } \\
\text { excitotoxicity that mediates neuronal cell death, contributing to learning and } \\
\text { memory impairment. }\end{array}$ & $\mathrm{KE}$ & Strong \\
\hline $\begin{array}{l}\text { Chronic binding of antagonist to N-methyl-D-aspartate receptors (NMDARs) during } \\
\text { brain development induces impairment of learning and memory abilities }\end{array}$ & $\mathrm{KE}$ & Strong \\
\hline Protein alkylation leading to liver fibrosis & KE & Strong \\
\hline $\begin{array}{l}\text { Binding of antagonist to N-methyl-D-aspartate receptors (NMDARs) during brain } \\
\text { development can trigger neuroinflammation and lead to neurodegeneration }\end{array}$ & $\mathrm{KE}$ & Moderate \\
\hline Lysosomal damage leading to liver inflammation & KE & Strong \\
\hline
\end{tabular}

How this Key Event works

\section{Level of biological organisation}

Cellular

Two types of cell death can be distinguished by morphological features, although it is likely that these are two ends of a spectrum with possible intermediate forms. Apoptosis involves shrinkage, 
nuclear disassembly, and fragmentation of the cell into discrete bodies with intact plasma membranes. These are rapidly phagocytosed by neighbouring cells. An important feature of apoptosis is the requirement for adenosine triphosphate (ATP) to initiate the execution phase. In contrast, necrotic cell death is characterised by cell swelling and lysis. This is usually a consequence of profound loss of mitochondrial function and resultant ATP depletion, leading to loss of ion homeostasis, including volume regulation, and increased $\mathrm{Ca}^{2+}$. The latter activates a number of nonspecific hydrolases (i.e. proteases, nucleases, and phospholipases) as well as calcium dependent kinases. Activation of calpain $\mathrm{I}$, the $\mathrm{Ca}^{2+}$-dependent cysteine protease cleaves the death-promoting Bcl-2 family members Bid and Bax which translocate to mitochondrial membranes, resulting in release of truncated apoptosis-inducing factor (tAIF), cytochrome $\mathrm{c}$ and endonuclease in the case of Bid and cytochrome $\mathrm{c}$ in the case of Bax. tAIF translocates to cell nuclei, and together with cyclophilin $\mathrm{A}$ and phosphorylated histone $\mathrm{H} 2 \mathrm{AX}(\gamma \mathrm{H} 2 \mathrm{AX})$ is responsible for DNA cleavage, a feature of programmed necrosis. Activated calpain I has also been shown to cleave the plasma membrane $\mathrm{Na}^{+}-\mathrm{Ca}^{2+}$ exchanger, which leads to build-up of intracellular $\mathrm{Ca}^{2+}$, which is the source of additional increased intracellular $\mathrm{Ca}^{2+}$. Cytochrome $\mathrm{c}$ in cellular apoptosis is a component of the apoptosome.

DNA damage activates nuclear poly(ADP-ribose) polymerase-1(PARP-1), a DNA repair enzyme. PARP-1 forms poly(ADP-ribose) polymers, to repair DNA, but when DNA damage is extensive, PAR accumulates, exits cell nuclei and travels to mitochondrial membranes, where it, like calpain $\mathrm{I}$, is involved in AIF release from mitochondria. A fundamental distinction between necrosis and apoptosis is the loss of plasma membrane integrity; this is integral to the former but not the latter. As a consequence, lytic release of cellular constituents promotes a local inflammatory reaction, whereas the rapid removal of apoptotic bodies minimises such a reaction. The distinction between the two modes of death is easily accomplished in vitro but not in vivo. Thus, although claims that certain drugs induce apoptosis have been made, these are relatively unconvincing. DNA fragmentation can occur in necrosis, leading to positive TUNEL staining. Conversely, when apoptosis is massive, it can exceed the capacity for rapid phagocytosis, resulting in the eventual appearance of secondary necrosis.

Two alternative pathways - either extrinsic (receptor-mediated) or intrinsic (mitochondriamediated) - lead to apoptotic cell death. The initiation of cell death begins either at the plasma membrane with the binding of TNF or FasL to their cognate receptors or within the cell. The latter is due to the occurrence of intracellular stress in the form of biochemical events such as oxidative stress, redox changes, covalent binding, lipid peroxidation, and consequent functional effects on mitochondria, endoplasmic reticulum, microtubules, cytoskeleton, or DNA. The intrinsic mitochondrial pathway involves the initiator, caspase-9, which, when activated, forms an "apoptosome" in the cytosol, together with cytochrome c, which translocates from mitochondria, Apaf-1 and dATP. The apoptosome activates caspase-3, the central effector caspase, which in turn activates downstream factors that are responsible for the apoptotic death of a cell (Fujikawa, 2015). Intracellular stress either directly affects mitochondria or can lead to effects on other organelles, which then send signals to the mitochondria to recruit participation in the death process (Fujikawa, 2015; Malhi et al., 2010). Constitutively expressed nitric oxide synthase (nNOS) is a $\mathrm{Ca}^{2+}$-dependent cytosolic enzyme that forms nitric oxide (NO) from L-arginine, and NO reacts with the free radical such as superoxide $\left(\mathrm{O}^{2-}\right)$ to form the very toxic free radical peroxynitrite $\left(\mathrm{ONOO}^{-}\right)$. Free radicals such as $\mathrm{ONOO}^{-}, \mathrm{O}^{2-}$ and hydroxyl radical $\left(\mathrm{OH}^{-}\right)$damage cellular membranes and intracellular proteins, enzymes and DNA (Fujikawa, 2015; Kaplowitz, 2002; Kroemer et al., 2009; Malhi et al., 2010). 


\section{How it is measured or detected}

\section{Necrosis:}

LDH is a soluble cytoplasmic enzyme that is present in almost all cells and is released into extracellular space when the plasma membrane is damaged. To detect the leakage of LDH into cell culture medium, a tetrazolium salt is used in this assay. In the first step, LDH produces reduced nicotinamide adenine dinucleotide $(\mathrm{NADH})$ when it catalyses the oxidation of lactate to pyruvate. In the second step, a tetrazolium salt is converted to a colored formazan product using newly synthesised NADH in the presence of an electron acceptor. The amount of formazan product can be colorimetrically quantified by standard spectroscopy. Because of the linearity of the assay, it can be used to enumerate the percentage of necrotic cells in a sample (Chan et al., 2013)

The MTT assay is a colorimetric assay for assessing cell viability. NAD(P)H-dependent cellular oxidoreductase enzymes may reflect the number of viable cells present. These enzymes are capable of reducing the tetrazolium dye MTT 3-(4,5-dimethylthiazol-2-yl)-2,5diphenyltetrazolium bromide to its insoluble formazan, which has a purple color. Other closely related tetrazolium dyes including XTT, MTS and the WSTs. Tetrazolium dye assays can also be used to measure cytotoxicity (loss of viable cells) or cytostatic activity (shift from proliferation to quiescence) of potential medicinal agents and toxic materials. MTT assays are usually done in the dark since the MTT reagent is sensitive to light (Berridge et al., 2005).

Propidium iodide (PI) is an intercalating agent and a fluorescent molecule used to stain necrotic cells. It is cell membrane impermeant so it stains only those cells where the cell membrane is destroyed. When PI is bound to nucleic acids, the fluorescence excitation maximum is $535 \mathrm{~nm}$ and the emission maximum is $617 \mathrm{~nm}$ (Moore et al., 1998).

\section{Apoptosis:}

TUNEL is a common method for detecting DNA fragmentation that results from apoptotic signalling cascades. The assay relies on the presence of nicks in the DNA which can be identified by terminal deoxynucleotidyl transferase or TdT, an enzyme that will catalyse the addition of dUTPs that are secondarily labeled with a marker. It may also label cells that have suffered severe DNA damage.

Caspase activity assays measured by fluorescence. During apoptosis, mainly caspase- 3 and -7 cleave PARP to yield an $85 \mathrm{kDa}$ and a $25 \mathrm{kDa}$ fragment. PARP cleavage is considered to be one of the classical characteristics of apoptosis. Antibodies to the $85 \mathrm{kDa}$ fragment of cleaved PARP or to caspase-3 both serve as markers for apoptotic cells that can be monitored using immunofluorescence (Li et al., 2004).

Hoechst 33342 staining: Hoechst dyes are cell-permeable and bind to DNA in live or fixed cells. Therefore, these stains are often called supravital, which means that cells survive a treatment with these compounds. The stained, condensed or fragmented DNA is a marker of apoptosis (Didenko, 2002; Kubbies and Rabinovitch, 1983). 
Evidence supporting taxonomic applicability

\begin{tabular}{|l|l|l|l|}
\hline \multicolumn{1}{|c|}{ Name } & Scientific name & Evidence & Links \\
\hline human & Homo sapiens & Strong & NCBI \\
\hline human and other cells in culture & & Strong & NCBI \\
\hline Rattus norvegicus & Rattus norvegicus & Strong & NCBI \\
\hline mouse & Mus musculus & Strong & NCBI \\
\hline
\end{tabular}

Cell death is an universal event occurring in cells of any species (Fink and Cookson, 2005).

\section{References}

Berridge, M.V., P.M. Herst and A.S. Tan (2005), Tetrazolium dyes as tools in cell biology: new insights into their cellular reduction. Biotechnology Annual Review, vol. 11, pp 127-152.

Chan, F.K., K. Moriwaki and M.J. De Rosa (2013), Detection of necrosis by release of lactate dehydrogenase (LDH) activity, Methods Mol Biol, vol. 979, pp. 65-70.

Fink, S.L. and B.T. Cookson (2005), Apoptosis, pyroptosis, and necrosis: mechanistic description of dead and dying eukaryotic cells, Infect Immun, vol. 73, no. 4, pp.1907-1916.

Fujikawa, D.G. (2015), The role of excitotoxic programmed necrosis in acute brain injury, Comput Struct Biotechnol J, vol. 13, pp. 212-221.

Kaplowitz, N. (2002), Biochemical and Cellular Mechanisms of Toxic Liver Injury, Semin Liver Dis, vol. 22, no. 2, www.medscape.com/viewarticle/433631 accessed on 20 January 2016.

Kroemer, G. et al., (2009), Classification of cell death: recommendations of the Nomenclature Committee on Cell Death, Cell Death Differ, vol. 16, no. 1, pp. 3-11.

Kubbies, M. and P.S. Rabinovitch (1983), Flow cytometric analysis of factors which influence the BrdUrdHoechst quenching effect in cultivated human fibroblasts and lymphocytes, Cytometry, vol. 3, no. 4, pp. 276-281.

Li, Peng et al. (2004), Mitochondrial activation of apoptosis, Cell, vol. 116, no. 2 Suppl, pp. S57-59, 2 p following S59.

Loo, D.T. (2002), TUNEL Assay an overview of techniques, Methods in Molecular Biology, vol. 203: In Situ Detection of DNA Damage, chapter 2, Didenko VV (ed.), Humana Press Inc.

Malhi, H. et al. (2010), Hepatocyte death: a clear and present danger, Physiol Rev, vol. 90, no. 3, pp. 11651194.

Moore, A, et al. (1998), Simultaneous measurement of cell cycle and apoptotic cell death, Methods Cell Biol, vol. 57, pp. 265-278. 


\section{Hepatic macrophages (Kupffer Cells), activation and recruitment}

AOPs including this Key Event

\begin{tabular}{|l|l|l|}
\hline \multicolumn{1}{|c|}{ AOP Name } & Event type & Essentiality \\
\hline Protein alkylation leading to liver fibrosis & KE & Strong \\
\hline
\end{tabular}

How this Key Event works

Level of biological organisation

Cellular

Kupffer cells (KCs) are a specialised population of macrophages that reside in the liver; they were first described by Carl Wilhelm von Kupffer (1829-1902) (Haubrich, 2004). KCs constitute $80 \%-90 \%$ of the tissue macrophages in the reticuloendothelial system and account for approximately $15 \%$ of the total liver cell population (Bouwens et al., 1986). They play an important role in normal physiology and homeostasis as well as participating in the acute and chronic responses of the liver to toxic compounds. Activation of KCs results in the release of an array of inflammatory mediators, growth factors, and reactive oxygen species. This activation appears to modulate acute hepatocyte injury as well as chronic liver responses including hepatic cancer. Understanding the role $\mathrm{KCs}$ play in these diverse responses is key to understanding mechanisms of liver injury (Roberts et al., 2007). Besides the release of inflammatory mediators including cytokines, chemokines, lysosomal and proteolytic enzymes KCs are a main source of TGF- $\beta 1$ (transforming growth factor-beta 1 , the most potent profibrogenic cytokine). In addition latent TGF- $\beta 1$ can be activated by KC-secreted matrix metalloproteinase 9 (MMP-9) (Luckey et al., 2001; Winwood et al., 1993) through the release of biologically active substances that promote the pathogenic process. Activated KCs also release ROS like superoxide generated by NOX (NADPH oxidase), thus contributing to oxidative stress. Oxidative stress also activates a variety of transcription factors like NF- $\kappa \mathrm{B}$, PPAR- $\gamma$ leading to an increased gene expression for the production of growth factors, inflammatory cytokines and chemokines. KCs express TNF- $\alpha$ (Tumor Necrosis Factor-alpha), IL-1 (Interleukin-1) and MCP-1 (monocyte-chemoattractant protein-1), all being mitogens and chemoattractants for hepatic stellate cells (HSCs) and induce the expression of PDGF receptors on HSCs which enhances cell proliferation. Expressed TNF- $\alpha$, TRAIL (TNF-related apoptosis-inducing ligand), and FasL (Fas Ligand) are not only proinflammatory active but also capable of inducing death receptor-mediated apoptosis in hepatocytes (Friedman, 2002; Guo and Friedman, 2007; Roberts et al., 2007). Under conditions of oxidative stress macrophages are further activated which leads to a more enhanced inflammatory response that again further activates KCs though cytokines (Interferon gamma (IFN $\gamma$ ), granulocyte macrophage colony-stimulating factor (GM-CSF), TNF- $\alpha$ ), bacterial lipopolysaccharides, extracellular matrix proteins, and other chemical mediators (Kershenobich Stalnikowitz and Weisssbrod, 2003; Kolios et al., 2006). Besides KCs, the resident hepatic macrophages, infiltrating bone marrow-derived macrophages, originating from circulating monocytes are recruited to the injured liver via chemokine signals. KCs appear essential for sensing tissue injury and initiating inflammatory responses, while infiltrating Ly-6C+ monocytederived macrophages are linked to chronic inflammation and fibrogenesis. The profibrotic 
functions of KCs (HSC activation via paracrine mechanisms) during chronic hepatic injury remain functionally relevant, even if the infiltration of additional inflammatory monocytes is blocked via pharmacological inhibition of the chemokine CCL2 (Baeck et al., 2012; Tacke and Zimmermann, 2014). KC activation and macrophage recruitment are two separate events and both are necessary for fibrogenesis, but as they occur in parallel, they can be summarised as one KE. Probably there is a threshold of $\mathrm{KC}$ activation and release above which liver damage is induced. Pre-treatment with gadolinium chloride $(\mathrm{GdCl})$, which inhibits $\mathrm{KC}$ function, reduced both hepatocyte and sinusoidal epithelial cell injury, as well as decreased the numbers of macrophages appearing in hepatic lesions and inhibited TGF- $\beta 1 \mathrm{mRNA}$ expression in macrophages. Experimental inhibition of $\mathrm{KC}$ function or depletion of KCs appeared to protect against chemical-induced liver injury (Ide et al., 2005).

\section{How it is measured or detected}

Kupffer cell activation can be measured by means of expressed cytokines, e.g. tissue levels of TNF-a (Vajdova et al., 2004), IL-6 expression, measured by immunoassays or Elisa (offered by various companies), soluble CD163 (Grønbaek et al., 2012; Møller, 2012) or increase in expression of Kupffer cell marker genes such as Lyz, Gzmb, and Il1b (Genome U34A Array, Affymetrix) (Takahara et al., 2006).

Evidence supporting taxonomic applicability

\begin{tabular}{|l|l|l|l|}
\hline \multicolumn{1}{|c|}{ Name } & Scientific name & Evidence & Links \\
\hline human & Homo sapiens & Strong & NCBI \\
\hline human and other cells in culture & & Strong & NCBI \\
\hline mouse & Mus musculus & Strong & NCBI \\
\hline Rattus norvegicus & Rattus norvegicus & Strong & NCBI \\
\hline
\end{tabular}

Human: Boltjes et al., 2014; Kegel et al., 2015; Su et al., 2002.

Rat: Luckey et al., 2001.

Mouse: Dalton et al., 2009.

\section{References}

Baeck, C. et al. (2012), Pharmacological inhibition of the chemokine CCL2 (MCP-1) diminishes liver macrophage infiltration and steatohepatitis in chronic hepatic injury, Gut, vol. 61, no. 3, pp. 416426.

Boltjes, A. et al. (2014), The role of Kupffer cells in hepatitis B and hepatitis C virus infections, J Hepatol, vol. 61 , no. 3 , pp. $660-671$.

Bouwens, L. et al. (1986), Quantitation, tissue distribution and proliferation kinetics of Kupffer cells in normal rat liver, Hepatology, vol. 6, no. 4, pp. 718-722.

Dalton, S.R. et al. (2009), Carbon tetrachloride-induced liver damage in asialoglycoprotein receptordeficient mice, Biochem Pharmacol, vol. 77, no. 7, pp. 1283-1290.

Friedman, S.L. (2002), Hepatic Fibrosis-Role of Hepatic Stellate Cell Activation, MedGenMed, vol. 4, no. 3, pp. 27. 
Grønbaek, H. et al. (2012), Soluble CD163, a marker of Kupffer cell activation, is related to portal hypertension in patients with liver cirrhosis, Aliment Pharmacol Ther, vol 36, no. 2, pp. 173-180.

Guo, J. and S.L. Friedman (2007), Hepatic Fibrogenesis, Semin Liver Dis, vol. 27, no. 4, pp. 413-426.

Haubrich, W.S. (2004), Kupffer of Kupffer cells, Gastroenterology, vol. 127, no. 1, p. 16.

Ide, M. et al. (2005), Effects of gadolinium chloride $(\mathrm{GdCl}(3))$ on the appearance of macrophage populations and fibrogenesis in thioacetamide-induced rat hepatic lesions, J. Comp. Path, vol. 133, no. 2-3, pp. 92-102.

Kegel, V. et al. (2015), Subtoxic concentrations of hepatotoxic drugs lead to Kupffer cell activation in a human in vitro liver model: an approach to study DILI, Mediators Inflamm, 2015:640631, http://doi.org/10.1155/2015/640631.

Kershenobich Stalnikowitz, D. and A.B. Weisssbrod (2003), Liver Fibrosis and Inflammation. A Review, Annals of Hepatology, vol. 2, no. 4, pp.159-163.

Kolios, G., V. Valatas and E. Kouroumalis (2006), Role of Kupffer Cells in the Pathogenesis of Liver Disease, World J.Gastroenterol, vol. 12, no. 46, pp. 7413-7420.

Luckey, S.W., and D.R. Petersen (2001), Activation of Kupffer cells during the course of carbon tetrachloride-induced liver injury and fibrosis in rats, Exp Mol Pathol, vol. 71, no. 3, pp. 226-240.

Møller, H.J. (2012), Soluble CD163.Scand J Clin Lab Invest, vol. 72, no. 1, pp. 1-13.

Roberts, R.A. et al. (2007), Role of the Kupffer cell in mediating hepatic toxicity and carcinogenesis, Toxicol Sci, vol. 96, no. 1, pp. 2-15.

$\mathrm{Su}$, G.L. et al. (2002), Activation of human and mouse Kupffer cells by lipopolysaccharide is mediated by CD14, Am J Physiol Gastrointest Liver Physiol, vol. 283, no. 3, pp. G640-645.

Tacke, F. and H.W. Zimmermann (2014), Macrophage heterogeneity in liver injury and fibrosis, J Hepatol, vol. 60, no. 5, pp. 1090-1096.

Takahara, T et al. (2006), Gene expression profiles of hepatic cell-type specific marker genes in progression of liver fibrosis, World J Gastroenterol, vol. 12, no. 40, pp. 6473-6499.

Vajdova, K. et al. (2004), Ischemic preconditioning and intermittent clamping improve murine hepatic microcirculation and Kupffer cell function after ischemic injury, Liver Transpl, vol. 10, no. 4, pp. $520-528$.

Winwood, P.J., and M.J. Arthur (1993), Kupffer cells: their activation and role in animal models of liver injury and human liver disease, Semin Liver Dis, vol. 13, no. 1, pp. 50-59.

\section{TGFbeta1 expression, up regulation}

AOPs including this Key Event

\begin{tabular}{|l|l|l|}
\hline \multicolumn{1}{|c|}{ AOP name } & Event type & Essentiality \\
\hline Protein alkylation leading to liver fibrosis & KE & Strong \\
\hline
\end{tabular}

How this Key Event works

Level of biological organisation

Cellular 
The transforming growth factor beta (TGF- $\beta$ ) family of cytokines is ubiquitous, multifunctional, and essential to survival. They play important roles in growth and development, inflammation and repair, and host immunity. The mammalian TGF- $\beta$ isoforms (TGF- $\beta 1, \beta 2$ and $\beta 3$ ) are secreted as latent precursors and have multiple cell surface receptors of which at least two mediate signal transduction. Autocrine and paracrine effects of TGF- $\beta$ s can be modified by extracellular matrix, neighbouring cells and other cytokines. The vital role of the TGF- $\beta$ family is illustrated by the fact that approximately $50 \%$ of TGF-1 gene knockout mice die in utero and the remainder succumbs to uncontrolled inflammation after birth. The role of TGF- $\beta$ in homeostatic and pathogenic processes suggests numerous applications in the diagnosis and treatment of various diseases characterised by inflammation and fibrosis (Clark and Coker, 1998; Pohlers et al., 2009; Santibañez et al., 2011). Abnormal TGF- $\beta$ regulation and function are implicated in a growing number of fibrotic and inflammatory pathologies, including pulmonary fibrosis, liver cirrhosis, glomerulonephritis and diabetic nephropathy, congestive heart failure, rheumatoid arthritis, Marfan syndrome, hypertrophic scars, systemic sclerosis, myocarditis, and Crohn's disease (Gordon and Blobe, 2008). TGF- $\beta 1$ is a polypeptide member of the TGF- $\beta$ superfamily of cytokines. TGF- $\beta$ is synthesised as a non-active pro-form, forms a complex with two latent associated proteins latency-associated protein (LAP) and latent TGF- $\beta$ binding protein (LTBP) and undergoes protolithic cleavage by the endopeptidase furin to generate the mature TGF- $\beta$ dimer. Among the TGF- $\beta$ s, six distinct isoforms have been discovered although only the TGF- $\beta 1$, TGF- $\beta 2$ and TGF- $\beta 3$ isoforms are expressed in mammals, and their human genes are located on chromosomes $19 q 13,1 q 41$ and $14 q 24$, respectively. Out of the three TGF- $\beta$ isoforms $(\beta 1, \beta 2$ and $\beta 3$ ) only TGF- $\beta 1$ was linked to fibrogenesis and is the most potent fibrogenic factor for hepatic stellate cells (Govinden and Bhoola, 2003; Roberts, 1998). During fibrogenesis, tissue and blood levels of active TGF- $\beta$ are elevated and overexpression of TGF- $\beta 1$ in transgenic mice can induce fibrosis. Additionally, experimental fibrosis can be inhibited by anti-TGF- $\beta$ treatments with neutralising antibodies or soluble TGF- $\beta$ receptors (Ceng et al., 2009; De Gouville et al., 2005; Qi et al., 1999; Shek and Benyon, 2004).

TGF- $\beta 1$ induces its own mRNA to sustain high levels in local sites of injury.The effects of TGF$\beta 1$ are classically mediated by intracellular signalling via Smad proteins. Smads 2 and 3 are stimulatory whereas Smad 7 is inhibitory (Friedman, 2008; Kubiczkova et al., 2012; Parsons, 2007). Smad1/5/8, MAP kinase (mitogen-activated protein) and PI3 kinase are further signalling pathways in different cell types for TGF- $\beta 1$ effects.

TGF- $\beta$ is found in all tissues, but is particularly abundant in bone, lung, kidney and placental tissue. TGF- $\beta$ is produced by many, but not all parenchymal cell types, and is also produced or released by infiltrating cells such as lymphocytes, monocytes/macrophages, and platelets. Following wounding or inflammation, all these cells are potential sources of TGF- $\beta$. In general, the release and activation of TGF- $\beta$ stimulates the production of various extracellular matrix proteins and inhibits the degradation of these matrix proteins (Branton and Kopp, 1999).

TGF- $\beta 1$ is produced by every leukocyte lineage, including lymphocytes, macrophages, and dendritic cells, and its expression serves in both autocrine and paracrine modes to control the differentiation, proliferation, and state of activation of these immune cells (Letterio and Roberts, 1998).

In the liver TGF- $\beta 1$ is released by activated Kupffer cells, liver sinusoidal endothelial cells, and platelets; in the further course of events also activated hepatic stellate cells express TGF- $\beta 1$. Hepatocytes do not produce TGF- $\beta 1$ but are implicated in intracellular activation of latent TGF$\beta 1$ (Kisseleva and Brenner, 2007; 2008; Liu et al., 2006; Poli, 2000; Roth et al., 1998). 
TGF- $\beta 1$ is the most established mediator and regulator of epithelial-mesenchymal-transition (EMT) which further contributes to the production of extracellular matrix. It has been shown that TGF- $\beta 1$ mediates EMT by inducing snail-1 transcription factor and tyrosine phosphorylation of Smad2/3 with subsequent recruitment of Smad4 (Bataller and Brenner, 2005; Brenner, 2009; Friedman, 2008; Gressner et al., 2002; Guo and Friedman, 2007; Kaimori, 2007; Kershenobich Stalnikowitz and Weissbrod, 2003; Kisseleva and Brenner, 2008; Kolios et al., 2006; Li, 2008; Liu et al., 2006; Matsuoka and Tsukamoto, 1990; Poli, 2000).

TGF- $\beta 1$ induces apoptosis and angiogenesis in vitro and in vivo through the activation of vascular endothelial growth factor (VEGF) High levels of VEGF and TGF- $\beta 1$ are present in many tumors. Crosstalk between the signalling pathways activated by these growth factors controls endothelial cell apoptosis and angiogenesis (Clark and Coker, 1998).

\section{How it is measured or detected}

There are several assays for TGB- $\beta 1$ measurement available, e.g. Human TGF- $\beta 1$ ELISA Kit. The Human TGF- $\beta 1$ ELISA (Enzyme -Linked Immunosorbent Assay) kit is an in vitro enzymelinked immunosorbent assay for the quantitative measurement of human TGF- $\beta 1$ in serum, plasma, cell culture supernatants, and urine. This assay employs an antibody specific for human TGF- $\beta 1$ coated on a 96-well plate. Standards and samples are pipetted into the wells and TGF- $\beta 1$ present in a sample is bound to the wells by the immobilised antibody. The wells are washed and biotinylated anti-human TGF- $\beta 1$ antibody is added. After washing away unbound biotinylated antibody, HRP- conjugated streptavidin is pipetted to the wells. The wells are again washed, a TMB substrate solution is added to the wells and colour develops in proportion to the amount of TGF- $\beta 1$ bound. The StopSolution changes the colour from blue to yellow, and the intensity of the colour is measured at $450 \mathrm{~nm}$ (Mazzieri, 2000).cite_note-32

Evidence supporting taxonomic applicability

\begin{tabular}{|l|l|l|l|}
\hline \multicolumn{1}{|c|}{ Name } & Scientific name & Evidence & Links \\
\hline human & Homo sapiens & Strong & NCBI \\
\hline Rattus norvegicus & Rattus norvegicus & Strong & NCBI \\
\hline mouse & Mus musculus & Strong & NCBI \\
\hline human and other cells in culture & & Strong & \\
\hline
\end{tabular}

Human: Santibanez et al., 2011.

Rat: Luckey et al., 2001.

Mouse: Nan et al., 2013.

\section{References}

Bataller, R. and D.A. Brenner (2005), Liver Fibrosis, J.Clin. Invest, vol. 115, no. 2, pp. 209-218.

Branton, M.H. and J.B. Kopp (1999), TGF-beta and fibrosis, Microbes Infect, vol. 1, no. 15, pp. 13491365.

Brenner, D.A. (2009), Molecular Pathogenesis of Liver Fibrosis, Trans Am Clin Climatol Assoc, vol. 120, pp. 361-368. 
Cheng, K., N.Yang and R.I. Mahato (2009), TGF-beta1 gene silencing for treating liver fibrosis, Mol Pharm, vol. 6, no. 3, pp. 772-779.

Clark, D.A. and R.Coker (1998), Transforming growth factor-beta (TGF-beta), Int J Biochem Cell Biol, vol. 30, no. 3, pp. 293-298.

De Gouville, A.C. et al. (2005), Inhibition of TGF-beta signaling by an ALK5 inhibitor protects rats from dimethylnitrosamine-induced liver fibrosis, Br J Pharmacol, vol. 145, no. 2, pp. 166-177.

Friedman, S.L. (2008), Mechanisms of Hepatic Fibrogenesis, Gastroenterology, vol. 134, no. 6, pp. 16551669.

Gordon, K.J. and G.C. Blobe (2008), Role of transforming growth factor- $\beta$ superfamily signaling pathways in human disease, Biochim Biophys Acta, vol. 1782, no. 4, pp. 197-228.

Govinden, R. and K.D. Bhoola (2003), Genealogy, expression, and cellular function of transforming growth factor- $\beta$, Pharmacol. Ther, vol. 98, no. 2, pp. 257-265.

Gressner, A.M. et al. (2002), Roles of TGF- $\beta$ in hepatic fibrosis. Front Biosci, vol. 7, pp. 793-807.

Guo, J. and S. L. Friedman (2007), Hepatic fibrogenesis, Semin Liver Dis, vol. 27, no. 4, pp. 413-426.

Kaimori, A. et al. (2007), Transforming growth factor-betal induces an epithelial-to-mesenchymal transition state in mouse hepatocytes in vitro, J Biol Chem, vol. 282, no. 30, pp. 22089-22101.

Kershenobich Stalnikowitz, D. and A.B. Weisssbrod (2003), Liver Fibrosis and Inflammation. A Review, Annals of Hepatology, vol. 2, no. 4, pp.159-163.

Kisseleva T and Brenner DA, (2008), Mechanisms of Fibrogenesis, Exp Biol Med, vol. 233, no. 2, pp. 109122.

Kisseleva, T. and Brenner, D.A. (2007), Role of hepatic stellate cells in fibrogenesis and the reversal of fibrosis, Journal of Gastroenterology and Hepatology, vol. 22, Suppl. 1; pp. S73-S78.

Kolios, G., V. Valatas and E. Kouroumalis (2006), Role of Kupffer cells in the pathogenesis of liver disease, World J.Gastroenterol, vol. 12, no. 46, pp. 7413-7420.

Kubiczkova, L. et al, (2012), TGF- $\beta$ - an excellent servant but a bad master, J Transl Med, vol. 10, p. 183.

Letterio, J.J. and A.B. Roberts (1998), Regulation of immune responses by TGF-beta, Annu Rev Immunol, vol.16, pp. 137-161.

Li, Jing-Ting et al. (2008), Molecular mechanism of hepatic stellate cell activation and antifibrotic therapeutic strategies, J Gastroenterol, vol. 43, no. 6, pp. 419-428.

Liu, Xingjun et al. (2006), Therapeutic strategies against TGF-beta signaling pathway in hepatic fibrosis. Liver Int, vol.26, no.1, pp. 8-22.

Luckey, S.W., and D.R. Petersen (2001), Activation of Kupffer cells during the course of carbon tetrachloride-induced liver injury and fibrosis in rats, Exp Mol Pathol, vol. 71, no. 3, pp. 226-240.

Matsuoka, M. and H. Tsukamoto, (1990), Stimulation of hepatic lipocyte collagen production by Kupffer cell-derived transforming growth factor beta: implication for a pathogenetic role in alcoholic liver fibrogenesis, Hepatology, vol. 11, no. 4, pp. 599-605.

Mazzieri, R .et al. (2000), Measurements of Active TGF- $\beta$ Generated by Culture Cells, Methods in Molecular Biology, vol. 142, pp. 13-27, DOI: 10.1385/1-59259-053-5:13.

Nan, Y.M. et al. (2013), Activation of peroxisome proliferator activated receptor alpha ameliorates ethanol mediated liver fibrosis in mice, Lipids Health Dis, vol. 12, p.11.

Parsons, C.J., M.Takashima and R.A. Rippe (2007), Molecular mechanisms of hepatic fibrogenesis. $J$ Gastroenterol Hepatol, vol. 22, Suppl.1, pp. S79-S84.

Pohlers , D. et al. (2009), TGF- $\beta$ and fibrosis in different organs - molecular pathway imprints, Biochim. Biophys. Acta, vol. 1792, no. 8, pp.746-756.

Poli, G. (2000), Pathogenesis of liver fibrosis: role of oxidative stress, Mol Aspects Med, vol. 21, no. 3, pp. $49-98$. 
Qi Z et al. (1999), Blockade of type beta transforming growth factor signaling prevents liver fibrosis and dysfunction in the rat, Proc Natl Acad Sci USA, vol. 96, no. 5, pp. 2345-2349.

Roberts, A.B. (1998), Molecular and cell biology of TGF- $\beta$, Miner Electrolyte Metab, vol. 24, no. 2-3, pp. 111-119.

Roth, S., K. Michel and A.M. Gressner (1998), (Latent) transforming growth factor beta in liver parenchymal cells, its injury-dependent release, and paracrine effects on rat HSCs, Hepatology, vol. 27, no. 4, pp. 1003-1012.

Santibañez J.F., M. Quintanilla and C. Bernabeu (2011), TGF- $\beta$ /TGF- $\beta$ receptor system and its role in physiological and pathological conditions, Clin Sci (Lond), vol. 121, no. 6, pp. 233-251.

Shek, F.W. and R.C. Benyon (2004), How can transforming growth factor beta be targeted usefully to combat liver fibrosis? Eur J Gastroenterol Hepatol, vol. 16, no. 2, pp.123-126.

\section{Stellate cells, activation}

AOPs including this Key Event

\begin{tabular}{|l|l|l|}
\hline \multicolumn{1}{|c|}{ AOP Name } & Event type & Essentiality \\
\hline Protein alkylation leading to liver fibrosis & KE & Strong \\
\hline
\end{tabular}

How this Key Event works

Level of biological organisation

Cellular

Stellate cell activation means a transdifferentiation from a quiescent vitamin A-storing cell to a proliferative and contractile myofibroblast. Multiple cells and cytokines play a part in the regulation of hepatic stellate cell (HSC) activation that consists of discrete phenotype responses, mainly proliferation, contractility, fibrogenesis, matrix degradation, chemotaxis, and retinoid loss. HSCs undergo activation through a two-phase process. The first step, the initiation phase, is triggered by injured hepatocytes, reactive oxygen species (ROS) and paracrine stimulation from neighbouring cell types (Kupffer cells (KCs), Liver sinusoidal endothelial cells (LSECs), and platelets) and make HSCs sensitised to activation by up-regulating various receptors. The perpetuation phase refers to the maintenance of HSC activation, which is a dynamic process including the secretion of autocrine and paracrine growth factors (such as TGF- $\beta 1$ ), chemokines, and the up-regulation of collagen synthesis (mainly type I collagen). In response to growth factors (including Platelet-derived Growth Factor (PDGF) and Vascular Endothelial Growth Factor (VEGF)) HSCs proliferate. Increased contractility (Endothelin-1 and NO are the key opposing counter-regulators that control HSC contractility, in addition to angiotensinogen II, and others) leads to increased portal resistance. Driven by chemoattractants their accumulation in areas of injury is enhanced. TGF- $\beta 1$ synthesis promotes activation of neighbouring quiescent hepatic stellate cells, whereas the release of HGF (hepatocyte growth factor) stimulates regeneration of adjacent hepatocytes. The release of chemoattractants (monocyte chemoattractant protein-1(MCP1) and colony-stimulating factors (CSFs)) amplifies inflammation (Bataller and Brenner, 2005; Friedman, 2010; Friedman, 2008; Friedman, 2000; Lee and Friedman, 2011; Lotersztain et al., 
2005; Poli, 2000). Activated HSCs (myofibroblasts) are the primary collagen producing cell, the key cellular mediators of fibrosis and a nexus for converging inflammatory pathways leading to fibrosis. Experimental inhibition of stellate cell activation prevents fibrosis (George al., 1999; Li et al., 2008).

How it is measured or detected

Alpha-smooth muscle actin ( $\alpha$-SMA) is a well-known marker of hepatic stellate cells activation. Anti-alpha smooth muscle Actin [1A4] monoclonal antibody reacts with the alpha smooth muscle isoform of actin.

Gene expression profiling confirmed early changes for known genes related to HSC activation such as alpha smooth muscle actin (Acta2), lysyl oxidase (Lox) and collagen, type I, alpha 1 (Col1a1). Insulin-like growth factor binding protein 3 (Igfbp3) was identified as a gene strongly affected and as marker for culture-activated HSCs and plays a role in HSC migration (Mannaerts et al., 2013; Morini et al., 2005).

Evidence supporting taxonomic applicability

\begin{tabular}{|l|l|l|l|}
\hline \multicolumn{1}{|c|}{ Name } & Scientific name & Evidence & Links \\
\hline human & Homo sapiens & Strong & NCBI \\
\hline Rattus norvegicus & Rattus norvegicus & Strong & NCBI \\
\hline mouse & Mus musculus & Strong & NCBI \\
\hline pig & Sus scrofa & Strong & NCBI \\
\hline human and other cells in culture & & Strong & \\
\hline
\end{tabular}

Human: Friedman, 2008.

Rat: George et al., 1999.

Mouse: Chang et al., 2014.

Pig: Costa et al., 2001.

\section{References}

Bataller, R. and D.A. Brenner (2005), Liver Fibrosis, J.Clin. Invest, vol. 115, no. 2, pp. 209-218.

Chang, W. et al. (2014), Isolation and culture of hepatic stellate cells from mouse liver, Acta Biochim Biophys Sin (Shanghai), vol. 46, no. 4, pp. 291-298.

Costa, A.M. et al. (2001), Early activation of hepatic stellate cells and perisinusoidal extracellular matrix changes during ex vivo pig liver perfusion, J Submicrosc Cytol Pathol, vol. 33, no. 3, pp. 231-240.

Friedman, S.L (2010), Evolving challenges in hepatic fibrosis, Nat. Rev. Gastroenterol. Hepatol, vol. 7, no. 8, pp. 425-436.

Friedman, S.L. (2008), Mechanisms of Hepatic Fibrogenesis, Gastroenterology, vol. 134, no. 6, pp. 16551669.

Friedman, S.L (2000), Molecular regulation of hepatic fibrosis, an integrated cellular response to tissue injury, J. Biol. Chem, vol. 275, no. 4, pp. 2247-2250. 
George, J. et al. (1999), In vivo inhibition of rat stellate cell activation by soluble transforming growth factor beta type II receptor: a potential new therapy for hepatic fibrosis. Proc Natl Acad Sci, vol. 96, no. 22, pp. 12719-12724.

Lee, U.E. and S.L. Friedman (2011), Mechanisms of Hepatic Fibrogenesis, Best Pract Res Clin Gastroenterol, vol. 25, no. 2, pp. 195-206.

$\mathrm{Li}$, Jing-Ting et al. (2008), Molecular mechanism of hepatic stellate cell activation and antifibrotic therapeutic strategies, J Gastroenterol, vol. 43, no. 6, pp. 419-428.

Lotersztain, S. et al. (2005), Hepatic fibrosis: molecular mechanisms and drug targets, Annu. Rev. Pharmacol. Toxicol, vol. 45, pp. 605-628.

Mannaerts, I. et al. (2013), Gene expression profiling of early hepatic stellate cell activation reveals a role for Igfbp3 in cell migration, PLoS One, vol. 8, no.12, e84071.

Morini, S. et al. (2005), GFAP expression in the liver as an early marker of stellate cells activation, Ital $J$ Anat Embryol, vol. 110, no. 4, pp. 193-207.

Poli, G. (2000), Pathogenesis of liver fibrosis: role of oxidative stress, Mol Aspects Med, vol. 21, no. 3, pp. $49-98$.

\section{Collagen, Accumulation}

AOPs including this Key Event

\begin{tabular}{|l|l|l|}
\hline \multicolumn{1}{|c|}{ AOP Name } & Event Type & Essentiality \\
\hline Protein alkylation leading to liver fibrosis & KE & Strong \\
\hline
\end{tabular}

How this Key Event works

Level of biological organisation

Tissue

Collagen is mostly found in fibrous tissues such as tendons, ligaments and skin. It is also abundant in corneas, cartilage, bones, blood vessels, the gut, intervertebral discs, and the dentin in teeth. In muscle tissue, it serves as a major component of the endomysium. Collagen is the main structural protein in the extracellular space in the various connective tissues, making up from $25 \%$ to $35 \%$ of the whole-body protein content. In normal tissues, collagen provides strength, integrity, and structure. When tissues are disrupted following injury, collagen is needed to repair the defect. If too much collagen is deposited, normal anatomical structure is lost, function is compromised, and fibrosis results.

The fibroblast is the most common collagen producing cell. Collagen-producing cells may also arise from the process of transition of differentiated epithelial cells into mesenchymal cells (EMT). This has been observed e.g. during renal fibrosis (transformation of tubular epithelial cells into fibroblasts) and in liver injury (transdifferentiation of hepatocytes and cholangiocytes into fibroblasts) (Henderson and Iredale, 2007). cite_note-1

There are close to 20 different types of collagen found with the predominant form being type I collagen. This fibrillar form of collagen represents over 90 percent of our total collagen and is 
composed of three very long protein chains which are wrapped around each other to form a triple helical structure called a collagen monomer. Collagen is produced initially as a larger precursor molecule called procollagen. As the procollagen is secreted from the cell, procollagen proteinases remove the extension peptides from the ends of the molecule. The processed molecule is referred to as collagen and is involved in fiber formation. In the extracellular spaces the triple helical collagen molecules line up and begin to form fibrils and then fibers. Formation of stable crosslinks within and between the molecules is promoted by the enzyme lysyl oxidase and gives the collagen fibers tremendous strength (Diegelmann, 2001). The overall amount of collagen deposited by fibroblasts is a regulated balance between collagen synthesis and collagen catabolism. Disturbance of this balance leads to changes in the amount and composition of collagen. Changes in the composition of the extracellular matrix initiate positive feedback pathways that increase collagen production.

Normally, collagen in connective tissues has a slow turn over; degradating enzymes are collagenases, belonging to the family of matrix metalloproteinases (MMPs). Other cells that can synthesise and release collagenase are macrophages, neutrophils, osteoclasts, and tumor cells (Di Lullo et al., 2001; Kivirikko and Risteli, 1976; Miller and Gay, 1987; Prockop and Kivirikko, 1995).

\section{How it is measured or detected}

Determination of the amount of collagen produced in vitro can be done in a variety of ways ranging from simple colorimetric assays to elaborate chromatographic procedures using radioactive and non-radioactive material. What most of these procedures have in common is the need to destroy the cell layer to obtain solubilised collagen from the pericellular matrix. Rishikof et al. (2005) describe several methods to assess the in vitro production of type I collagen: Western immunoblotting of intact alpha1(I) collagen using antibodies directed to alpha1(I) collagen amino and carboxyl propeptides, the measurement of alpha1(I) collagen mRNA levels using real-time polymerase chain reaction, and methods to determine the transcriptional regulation of alpha1(I) collagen using a nuclear run-on assay.

Evidence supporting taxonomic applicability

\begin{tabular}{|l|l|l|l|}
\hline \multicolumn{1}{|c|}{ Name } & Scientific name & Evidence & Links \\
\hline human & Homo sapiens & Strong & NCBI \\
\hline Rattus norvegicus & Rattus norvegicus & Strong & NCBI \\
\hline mouse & Mus musculus & Strong & NCBI \\
\hline
\end{tabular}

Human: Bataller and Brenner, 2009; Decaris et al., 2015.

Mouse: Dalton et al., 2009; Leung et al., 2008, Nan et al., 2013.

Rat: Hamdy and El-Demerdash, 2012; Li et al., 2012; Luckey and Peterson, 2001; Natajaran et al., 2006.

\section{References}

Bataller, R. and D.A. Brenner (2005), Liver Fibrosis, J.Clin. Invest, vol. 115, no. 2, pp. 209-218.

Dalton, S.R. et al. (2009), Carbon tetrachloride-induced liver damage in asialoglycoprotein receptordeficient mice, Biochem Pharmacol, vol. 77, no. 7, pp. 1283-1290. 
Decaris, M.L. et al. (2015), Turnover rates of hepatic collagen and circulating collagen-associated proteins in humans with chronic liver disease, PLoS One, vol. 10, no. 4, e0123311.

Di Lullo, G.A. et al. (2001), Mapping the Ligand-binding Sites and Disease-associated Mutations on the Most Abundant Protein in the Human, Type I Collagen, J. Biol. Chem, vol. 277, no. 6, pp. 4223 4231.

Diegelmann, R.F. (2001), Collagen Metabolism, Wounds, vol. 13, no. 5, available at www.medscape.com/viewarticle/423231 (accessed on 20 Jamuary 2016).

Hamdy, N. and E. El-Demerdash. (2012), New therapeutic aspect for carvedilol: antifibrotic effects of carvedilol in chronic carbon tetrachloride-induced liver damage, Toxicol Appl Pharmacol, vol. 261, no. 3, pp. 292-299.

Henderson, N.C. and J.P. Iredale (2007), Liver fibrosis: cellular mechanisms of progression and resolution, Clin Sci (Lond), vol. 112, no. 5, pp. 265-280.

Kivirikko, K.I. and L. Risteli (1976), Biosynthesis of collagen and its alterations in pathological states, Med Biol, vol. 54, no. 3, pp. 159-186.

Leung, T.M. et al. (2008), Endothelial nitric oxide synthase is a critical factor in experimental liver fibrosis, Int J Exp Pathol, vol. 89, no. 4, pp. 241-250.

Li, Li et al. (2012), Establishment of a standardized liver fibrosis model with different pathological stages in rats, Gastroenterol Res Pract; vol. 2012, Article ID 560345.

Luckey, S.W., and D.R. Petersen (2001), Activation of Kupffer cells during the course of carbon tetrachloride-induced liver injury and fibrosis in rats, Exp Mol Pathol, vol. 71, no. 3, pp. 226-240.

Miller, E.J. and S. Gay (1987), The collagens: an overview and update, Methods Enzymol, vol. 144, pp. 341.

Nan, Y.M. et al. (2013), Activation of peroxisome proliferator activated receptor alpha ameliorates ethanol mediated liver fibrosis in mice, Lipids in Health and Disease, vol. 12, p. 11.

Natajaran, S.K. et al. (2006), Oxidative stress in the development of liver cirrhosis: a comparison of two different experimental models, J Gastroenterol Hepatol, vol. 21, no. 6, pp. 947-957.

Prockop, D.J. and K.I. Kivirikko (1995), Collagens: molecular biology, diseases, and potentials for therapy, Annu Rev Biochem, vol. 64, pp. 403-434.

Rishikof, D.C. et al. (2005), Methods for measuring type I collagen synthesis in vitro, Methods, Mol Med, vol. 117, pp.129-140.

\section{Adverse Outcome}

\section{Adverse Outcome}

Liver fibrosis, N/A

\section{Liver fibrosis, N/A}

AOPs including this Key Event

\section{AOP Name}

Event Type Essentiality

Protein alkylation leading to liver fibrosis $\mathrm{AO}$ 
Affected Organs

\begin{tabular}{|c|c|l|l|}
\hline Synonym & Scientific name & Evidence & Links \\
\hline liver parenchyme & liver parenchyma & Ontobee \\
\hline
\end{tabular}

How this Key Event works

Level of biological organisation

Organ

Liver fibrosis results from perpetuation of the normal wound healing response, as a result of repeated cycles of hepatocyte injury and repair and is a dynamic process, characterised by an excessive deposition of ECM (extracellular matrix) proteins including glycoproteins, collagens, and proteoglycans. It is usually secondary to hepatic injury and inflammation, and progresses at different rates depending on the aetiology of liver disease and is also influenced by environmental and genetic factors. If fibrosis continues, it disrupts the normal architecture of the liver, altering the normal function of the organ and ultimately leading to liver damage. Cirrhosis represents the final stage of fibrosis. It is characterised by fibrous septa which divide the parenchyma into regenerative nodules which leads to vascular modifications and portal hypertension with its complications of variceal bleeding, hepatic encephalopathy, ascites, and hepatorenal syndrome. In addition, this condition is largely associated with hepatocellular carcinoma with a further increase in the relative mortality rate (Bataller and Brenner, 2005; Merck Manual).

Liver fibrosis is an important health issue with clear regulatory relevance. The burden of disease attributable to liver fibrosis is quite high; progressive hepatic fibrosis, ultimately leading to cirrhosis, is a significant contributor to global health burden (Lim and Kim; 2008). In the European Union, $0.1 \%$ of the population is affected by cirrhosis, the most advanced stage of liver fibrosis with full architectural disturbances (Blachier et al., 2013). Besides the epidemiological relevance, liver fibrosis also imposes a considerable economic burden on society. Indeed, the only curative therapy for chronic liver failure is liver transplantation. More than 5.500 orthotopic liver transplantations are currently performed in Europe on a yearly basis, costing up to $€ 100.000$ the first year and $€ 10.000$ yearly thereafter (Van Agthoven et al., 2001). Therefore, much effort is put in research to find therapeutic strategies.

\section{How it is measured or detected}

Liver biopsy is an important part of the evaluation of patients with a variety of liver diseases. Besides establishing the diagnosis, the biopsy is often used to assess the severity of the disease. Until recently it has been assumed that fibrosis is an irreversible process, so most grading and staging systems have relatively few stages and are not very sensitive for describing changes in fibrosis. In all systems, the stages are determined by both the quantity and location of the fibrosis, with the formation of septa and nodules as major factors in the transition from one stage to the next. The absolute amount of fibrous tissue is variable within each stage, and there is considerable overlap between stages. Commonly used systems are the Knodell score with 4 stages - no fibrosis (score 0 ) to fibrous portal expansion (score 2) to bridging fibrosis (score 3) and Cirrhosis (score 4) - and the more sensitive Ishak fibrosis score with six stages - from no fibrosis (stage 0) over 
increasing fibrous expansion on portal areas (stages 1-2), bridging fibrosis (stages 3-4), and nodules (stage 5) to cirrhosis (stage 6) (Goodman., 2007). Liver biopsy is an invasive test with many possible complications and the potential for sampling error. Noninvasive tests become increasingly precise in identifying the amount of liver fibrosis through computer-assisted image analysis. Standard liver tests are of limited value in assessing the degree of fibrosis. Direct serologic markers of fibrosis include those associated with matrix deposition - e.g. procollagen type III amino-terminal peptide (P3NP), type I and IV collagens, laminin, hyaluronic acid, and chondrex. P3NP is the most widely studied marker of hepatic fibrosis. Other direct markers of fibrosis are those associated with matrix degradation, ie, matrix metalloproteinases 2 and 3 (MMP-2, MMP- 3) and tissue inhibitors of metalloproteinases 1 and 2 (TIMP-1, TIMP-2). These tests are not commercially available, and the components are not readily available in most clinical laboratories. Some indirect markers that combine several parameters are available but not very reliable. Conventional imaging studies (ultrasonography and computed tomography) are not sensitive for fibrosis. Hepatic elastography, a method for estimating liver stiffness, is a recent development in the noninvasive measurement of hepatic fibrosis. Currently, elastography can be accomplished by ultrasound or magnetic resonance. Liver biopsy is still needed if laboratory testing and imaging studies are inconclusive (Carey, 2010; Germani et al., 2012).

Evidence supporting taxonomic applicability

\begin{tabular}{|l|l|l|l|}
\hline \multicolumn{1}{|c|}{ Name } & Scientific name & Evidence & Links \\
\hline human & Homo sapiens & Strong & NCBI \\
\hline Rattus norvegicus & Rattus norvegicus & Strong & NCBI \\
\hline mouse & Mus musculus & Strong & NCBI \\
\hline
\end{tabular}

Human: Bataller and Brenner, 2005; Blachier M. et al., 2013; Merck Manual.

Rat, mouse; Liedtke et al., 2013.

Regulatory examples using this adverse outcome

From the OECD - Guidance Document on developing and assessing Adverse Outcome Pathways - Series on Testing and Assessment 18 [ENV/JM/MONO(2013)6]: "...an adverse effect that is of regulatory interest (e.g. repeated dose liver fibrosis)".

\section{References}

Bataller, R. and D.A. Brenner (2005), Liver Fibrosis, J.Clin. Invest, vol. 115, no. 2, pp. 209-218.

Blachier, M. et al. (2013), The burden of liver disease in Europe: a review of available epidemiological data, J Hepatol, vol. 58, no. 3, pp. 593-608.

Carey, E. (2010), Noninvasive tests for liver disease, fibrosis, and cirrhosis: Is liver biopsy obsolete? Cleveland Clinic Journal of Medicine, vol. 77, no. 8, pp. 519-527.

Germani, G. et al. (2011), Assessment of Fibrosis and Cirrhosis in Liver Biopsies, Semin Liver Dis, vol. 31, no. 1, pp. 82-90. available at www.medscape.com/viewarticle/743946_2, (accessed 10 February 2015). 
Goodman, Z.D. (2007), Grading and staging systems for inflammation and fibrosis in chronic liver diseases, Journal of Hepatology, vol. 47, no. 4, pp. 598-607.

Liedtke, C. et al. (2013), Experimental liver fibrosis research: update on animal models, legal issues and translational aspects, Fibrogenesis Tissue Repair, vol. 6, no. 1, p. 19.

Lim, Y. and W. Kim (2008), The global impact of hepatic fibrosis and end-stage liver disease, Clin Liver Dis, vol. 12, no. 4, pp. 733-746.

Merck Manual available at: www.merckmanuals.com/professional/hepatic-and-biliary-disorders/fibrosisand-cirrhosis/hepatic-fibrosis, (accessed 10 February 2015).

Van Agthoven, M. et al. (2001), A comparison of the costs and effects of liver transplantation for acute and for chronic liver failure. Transpl Int, vol. 14, no. 2, pp. 87-94.

\section{Key Event Relationships: Scientific evidence supporting the linkages in the AOP}

\begin{tabular}{|l|l|l|}
\hline \multicolumn{1}{|c|}{ Event } & \multicolumn{1}{|c|}{ Description } & \multicolumn{1}{c|}{ Triggers } \\
\hline Protein, alkylation & $\underline{\text { Directly leads to }}$ & $\underline{\text { Cell death, N/A }}$ \\
\hline$\underline{\text { Cell death, N/A }}$ & $\underline{\text { Directly leads to }}$ & $\begin{array}{l}\text { Hepatic macrophages (Kupffer Cells), } \\
\text { activation }\end{array}$ \\
\hline$\underline{\text { Cell death, N/A }}$ & $\underline{\text { Indirectly leads }}$ & $\underline{\text { Stollate cells, activation }}$ \\
\hline$\underline{\text { Hepatic macrophages (Kupffer Cells), }}$ & $\underline{\text { Directly leads to }}$ & $\underline{\text { TGFbetal expression, up regulation }}$ \\
\hline$\underline{\text { TGtivation }}$ & $\underline{\text { Directly leads to }}$ & $\underline{\text { Stellate cells, activation }}$ \\
\hline$\underline{\text { Stellate cells, activation }}$ & $\underline{\text { Directly leads to }}$ & Collagen, accumulation \\
\hline$\underline{\text { Collagen, accumulation }}$ & $\underline{\text { Directly leads to }}$ & $\underline{\text { Liver fibrosis, N/A }}$ \\
\hline
\end{tabular}

\section{Protein, alkylation leads to cell death, N/A}

How does this Key Event Relationship work

Alkylating agents are highly reactive chemicals that may produce cellular damage by covalently binding to cellular macromolecules to form adducts and thereby preventing their proper functioning. Covalent protein alkylation by reactive electrophiles was identified as a key triggering event in chemical toxicity; it disturbs the cellular redox balance - contributing also to the development of oxidative stress - through interaction with glutathione, which leads to disruption of multiple biochemical pathways in exposed cells and is associated with mitochondrial dysfunction, which in turn, can trigger the death of exposed cells via either apoptosis and/or necrosis (Boll et al., 2001; Manibusan et al., 2007; Rudolph and Freeman., 2009; Schopfer et al., 2011; Tanel et al. 2007). 
For example, Acrolein, the metabolite of Allyl Alcohol is a highly reactive electrophilic aldehyde and rapidly binds to cellular nucleophiles like glutathione. Thiol redox balance is critical for numerous cell functions Acrolein has been identified as both a product and initiator of lipid peroxidation (Kehrer and Biswal, 2000). The high toxic potential of Acrolein reflects its possession of two strongly electrophilic centres which ensure it readily reacts with nucleophilic groups on biological molecules including glutathione and proteins. These reactions typically proceed via Michael addition of nucleophiles to the a,b-unsaturated bond of Acrolein, generating carbonyl-retaining adducts with the ability to undergo further crosslinking. Reaction of the carbonyl group in the first instance to form Schiff base adducts is typically much less preferred. Adduction of a diverse range of targets, in addition to disruption of the cellular redox balance, appears to underlie the disruption of multiple biochemical pathways in Acrolein-exposed cells. Such events can trigger the death of exposed cells via either apoptosis and/or necrosis (Thompson and Burcham, 2008). cite note-Thompson2008-7

It has been suggested that the alkylation of nucleophilic groups of cellular macromolecules effected by Acrolein after glutathione depletion is the event actually leading to cell injury (Pompella et al., 1991).

Another example for an alkylating agent is Carbon Tetrachloride $\left(\mathrm{CCl}_{4}\right)$, for which consensus has emerged that its toxicity is a mutifactorial process involving the generation of $\mathrm{CCl}_{4}$-derived free radicals, lipid peroxidation, covalent binding to macromolecules, loss of calcium homeostasis, nucleic acid hypomethylation and inflammatory cytokines. $\mathrm{CCl}_{4}$-derived free radicals are highly reactive species that are able to alkylate proteins and nucleic acids to generate $\mathrm{CCl}_{4}$-derived adducts (Knockaert et al., 2012). cite note-9

\section{Weight of Evidence}

\section{Biological plausibility}

Cell injury caused by covalent binding is biologically plausible. The mechanistic relationship between MIE and KE 1 is consistent with established biological knowledge (Codreanu et al., 2014; Kehrer and Biswal, 2000; Liebler, 2008).

Empirical support for linkage

Even though protein alkylation is a generic process having an impact on multiple physiological processes in the cell, certain connections related to which alkylated proteins lead and/or contribute to cell injury have been described with high biological plausibility. Better understanding of the effects of alkylating agents at the molecular level is aided by recent application of new toxicogenomics technologies (Golla, 2015). However, further efforts are certainly needed. Here we list literature-based evidence on how protein alkylation induced by allyl alcohol and carbon tetrachloride $\left(\mathrm{CCl}_{4}\right)$ could be leading to cell injury (apoptosis/necrosis).

Allyl alcohol/Acrolein-induced apoptosis of human cells is associated with depletion of cellular GSH and intracellular generation of oxidants (Nardini, 2002), achieved by alkylation of various proteins involved in the process (Randall 2013, Reddy 2002). More specifically, allyl alcohol/acrolein is considered a mitochondrial toxin that leads to cell death (Moghe, 2015). Whether apoptosis or necrosis ensues after acrolein exposure appears to be related to dose and cell type. In regards to activation of caspases as part of the mitochondrial death pathway it was shown 
that apoptosis could be both caspase-dependent: in human neuroblastoma cells (Dong et al., 2013) and in A549 lung cells (Roy et al., 2009), as well as caspase-independent: in CHO cells (Tanel and Averill-Bates, 2005). It was suggested that the activation of certain caspases may arise from a partial inhibition of their active site cysteine residue through direct alkylation by acrolein (Kern and Kehrer, 2002).

Furthermore, using biotin hydrazide labeling, it was shown that NF- $\mathrm{BB}$ RelA and p50, as well as JNK2, were revealed as direct targets for alkylation by acrolein, affecting the GSH depletion. Mass spectrometry analysis of acrolein-modified recombinant JNK2 indicated adduction to Cys(41) and Cys(177), putative important sites involved in mitogen-activated protein kinase (MAPK) kinase (MEK) binding and JNK2 phosphorylation (Hristova, 2012). In complimentary work, exposure of cultured hepatocytes to acrolein led to a sustained activation of ERK1/2, JNK, and p38, which was associated with ER and mitochondrial stress and apoptosis. The cytotoxic effects of acrolein were decreased by JNK inhibitor, suggesting that kinase activation may be linked to cell death and liver injury (Mohammad et al., 2012).

Schwend et al. (2008) tried to identify new proteins that undergo alkylation by acrylamide by treating three human cell lines (Jurkat, Caco-2 and HepG2 cells) with acrylamide and analysing extracted proteins by MALDI-TOF for potentially alkylated candidates. They could identify two novel acrylamide target proteins that may contribute to the toxicity of acrylamide in cell cultures. Acrylamide showed dose-dependent cytotoxic effects in all three tested cultures (IC50 2-4 mM for the three cell lines). Protein alkylation could be observed already at lower, sub-cytotoxic doses $(10 \mathrm{uM})$. Their data confirmed that acrylamide causes cytotoxicity effects in cell cultures and this cytotoxicity is most likely mediated by protein alkylation.

Thompson and Burcham (2008) studied the impact of culture media composition on the extent of damage occurring at protein targets within acrolein-exposed cells (A549 cells), and saw that acrolein induced concentration- dependent damage to cell proteins and increased cytochrome $\mathrm{c}$ release as marker of apoptotic cell death

Cai et al. (2005) investigated the mitochondria-initiated apoptosis pathway involved in $\mathrm{CCl}_{4}$ hepatotoxicity in vitro and observed a time-and dose-dependent decrease in cellular glutathione content, along with a concomitant increase in malondialdehyde levels following the application of $\mathrm{CCl}_{4}$. Caspase 3 activity was stimulated at all doses of $\mathrm{CCl}_{4}$, with the most significant activation at $3 \mathrm{mmol} / \mathrm{L}$. Cytochrome c was released obviously after $\mathrm{CCl}_{4}$ treatment. A time-dependent decrease in Bcl-XL expression was observed. DNA fragmentation results revealed apoptosis and necrosis following $\mathrm{CCl} 4$ treatment. They concluded that oxidative damage is one of the essential mechanisms of $\mathrm{CCl} 4$ hepatotoxicity, which triggers apoptosis via the mitochondria-initiated pathway.

Perrissoud et al. (1980) investigated the effect of $\mathrm{CCl}_{4}$ on isolated rat hepatocytes. The ultrastructural alterations and release of lactate dehydrogenase (LDH) and glutamate-oxaloacetate transaminase (GOT), were recorded after different periods of incubation. After 5 min incubation with $\mathrm{CC}_{4}$, morphological changes observed by electron microscopy, involved the plasma membrane. The endoplasmic reticulum and mitochondria were altered later. These morphological alterations were accompanied by an early release of $\mathrm{LDH}$ and GOT into the incubation medium. 
Johnston and Kroening (1998) investigated mechanisms of early carbon tetrachloride toxicity in cultured rat hepatocytes and found that primary rat hepatocytes in culture were killed after a $2 \mathrm{hr}$ incubation with $\mathrm{CCl}_{4}$ gas at partial pressures above a threshold between 45 and $54 \mathrm{mmHg}$. They concluded that early hepatocyte death in cell culture is independent of metabolism of $\mathrm{CCl}_{4}$, and may be related to direct effects of $\mathrm{CCl} 4$ on intracellular membranes.

Boll et al. (2001a, 2001b) modelled $\mathrm{CCl}_{4}$-induced liver damage in monolayer cultures of rat primary hepatocytes with a focus on involvement of covalent binding of $\mathrm{CC}_{4}$ metabolites to cell components and/ or peroxidative damage as the cause of injury. They observed that covalent binding of $14 \mathrm{C}$-labelled metabolites was detected in hepatocytes immediately after exposure to CC14. Electrophoresis of microsomal proteins from [14C]-CCl4-treated hepatocytes revealed that, aside of the start and the front of the gel, radioactive label was found primarily between 70 and $80 \mathrm{kDa}$.cite_note-Boll2001-2

In a study performed on isolated hepatocytes it was demonstrated that direct alkylation of critical sulfhydryl groups in proteins leads to a sustained increase in free $\mathrm{Ca}^{2+}$ concentrations which, via $\mathrm{Ca}^{2+}$ - dependent protease activates the enzyme xantine oxidase. This activation generates a substantial amount of superoxide anion free radical and other ROS that oxidise other protein sulfhydryl groups. Thiol depletion in the cytoplasm is primarily linked to the alkylation by the reactive metabolite acrolein (Zwilling and Balduini, 1992).cite_note-12

Boot (1996) described toxicological data of organic mercury compounds (alkylating agents) in rat hepatocytes, primary human hepatocytes, and in situ perfused total rat livers. Significant effects like induction of glutathione depletion, inhibition of cellular glucose and amino acid uptake with blocked albumin synthesis were observed in almost all tested physiological parameters.

Codreanu et al. (2014) intended to profile the accumulation of proteome damage in human cells (RKO and THP-1 cells) treated with lipid electrophile probes. Damage occurred selectively across functional protein interaction networks, with the most highly alkylation- susceptible proteins mapping to networks involved in cytoskeletal regulation.

\section{Uncertainties or inconsistencies}

Though covalent protein alkylation by reactive electrophiles was identified as a key triggering event in chemical toxicity already over 40 years ago and despite the intense effort expended over the past few years, our understanding of the mechanism and consequences of protein modification by reactive intermediates - both oxidising and alkylating agents - is still quite limited. Covalent protein alkylation is a feature of many hepatotoxic drugs and the overall extent of binding does not adequately distinguish toxic from non-toxic binding. Directly relating covalent binding to hepatotoxicity is likely an oversimplification of the process whereby adduct formation ultimately leads to toxicity. Understanding underlying complexities (e.g., which macromolecules are important covalent binding targets) will be essential to any understanding of the problem of metabolism-dependent hepatotoxicity and predicting toxicity from in vitro experiments (Bauman et al., 2009; Bauman et al., 2008). Data from Codreanu et al. (2014) suggest that non-toxic covalent binding may largely be survivable damage to cytoskeletal components and other highly reactive protein targets, whereas toxic covalent binding produces lethal injury by targeting protein synthesis and catabolism and possibly mitochondrial electron transport. Future studies with 
appropriate probe molecules for toxic and non-toxic drugs could test these hypotheses and provide a better mechanistic basis for interpreting protein alkylation in drug safety evaluation.

For this AOP it is not known whether protein alkylation to certain proteins is required and whether particular proteins and various binding sites influence the further downstream process. Further we do not know whether there is a threshold and if this threshold would refer to the number of alkylation of a single protein or of a threshold number of proteins.

\section{Quantitative understanding of the linkage}

Quantitative data are hardly available.

Schwend et al (2008) found that Acrylamide concentrations causing serious cytotoxicity were 2 $4 \mathrm{mM}$. Acrylamide toxicity in vivo and in vitro is most likely the result of protein alkylation. Protein alkylation could be observed already at lower, sub-cytotoxic doses (10uM). The effects were dose-dependent and these IC 50 values were found for the three treated cell types: Jurkat cells: $2 \mathrm{mM}$, HepG2 cells: $2 \mathrm{mM}$, Caco-2 cells: $4 \mathrm{mM}$. Cells were grown in 96-well plates and treated with acrylamide for $48 \mathrm{~h}$. Cell viability was measured by the MTT assay $(0.05 \mathrm{mg} / \mathrm{mL}$ MTT). IC50 values were calculated from dose-response curves $48 \mathrm{~h}$ after acrylamide treatment.

Codreanu et al. (2014) performed adduct profiling experiments with alkynyl analogs of the prototypical lipid electrophiles 4-hydroxy-2-nonenal (HNE) and 4-oxo-2-nonenal (ONE) in human colorectal carcinoma (RKO) cells and human monocytic leukemia (THP-1) cells. Treatment with aHNE and aONE produced widespread protein alkylation in both cell types. IC50 concentrations for HNE and ONE and their alkynyl analogs in both cell types were $20 \mathrm{uM}$. Protein alkylation could be observed already at nontoxic concentrations ( 5 and 10uM).cite_noteCodreanu_2014-10

Evidence supporting taxonomic applicability

\begin{tabular}{|l|l|l|l|}
\hline \multicolumn{1}{|c|}{ Name } & Scientific name & Evidence & Links \\
\hline human & Homo sapiens & Strong & NCBI \\
\hline Rattus norvegicus & Rattus norvegicus & Strong & NCBI \\
\hline
\end{tabular}

Human: Schwend et al., 2008.

Rat: Boot, 1996.

\section{References}

Bauman, J.N. et al. (2009), Can in vitro metabolism-dependent covalent binding data distinguish hepatotoxic from nonhepatotoxic drugs? An analysis using human hepatocytes and liver S-9 fraction, Chem Res Toxicol, vol. 22, no. 2, pp. 332-340.

Bauman, J.N. et al. (2008), Comparison of the bioactivation potential of the antidepressant and hepatotoxin nefazodone with aripiprazole, a structural analog and marketed drug, Drug Metab. Dispos, vol. 36, no. 6, pp. 1016-1029.

Boll, M. et al. (2001a), Pathogenesis of Carbon Tetrachloride-induced hepatocyte injury bioactivation of CCI4 by cytochrome P450 and effects on lipid homeostasis. $Z$ Naturforsch $C$, vol. 56, no. 1-2, pp. 111-121. 
Boll, M. et al. (2001b), Mechanism of carbon tetrachloride-induced hepatotoxicity. Hepatocellular damage by reactive carbon tetrachloride metabolites, $Z$ Naturforsch $C$, vol. 56, no. 7-8, pp. 649-659.

Boot, J.H. (1996), Hepatotoxic effects of SH-reagents in human and rat hepatocyte cultures and in situ perfused rat livers, Cell Structure and Function, vol. 2, no. 4, pp. 221-229.

Cai, Y. et al. (2005), Apoptosis initiated by carbon tetrachloride in mitochondria of rat primary cultured hepatocytes, Acta Pharmacol Sin, vol. 26, no. 8, pp. 969-975.

Codreanu, S.G. et al. (2014), Alkylation damage by lipid electrophiles targets functional protein systems, Molecular \& Cellular Proteomics, vol. 13, no. 3, pp.849-859.

Dong, L. et al. (2013), Magnolol protects against oxidative stress-mediated neural cell damage by modulating mitochondrial dysfunction and PI3K/Akt signaling, J Mol Neurosci, vol. 50, no. 3, pp. 469-481.

Golla, U., G. Bandi and R.S.Tomar (2015), Molecular cytotoxicity mechanisms of allyl alcohol (acrolein) in budding yeast, Chem Res Toxicol. vol. 28, no. 6, pp.1246-1264.

Hristova, M. et al. (2012), The tobacco smoke component, acrolein, suppresses innate macrophage responses by direct alkylation of c-Jun N-terminal kinase, Am J Respir Cell Mol Biol, vol. 46, no. 1, pp. 23-33.

Johnston, D.E. and C. Kroening, Mechanism of early carbon tetrachloride toxicity in cultured rat hepatocytes, Pharmacol Toxicol. vol. 83, no.6, pp. 231-239.

Kehrer, J.P. and S. Biswal (2000), The Molecular Effects of Acrolein, Toxicol. Sciences, vol. 57, no. 1, pp. 6-15.

Kern, J.C. and J.P. Kehrer (2002), Acrolein-induced cell death: a caspase-influenced decision between apoptosis and oncosis/necrosis, Chem Biol Interact, vol.139, no.1, pp.79-95.

Knockaert, L. et al. (2012), Carbon tetrachloride-mediated lipid peroxidation induces early mitochondrial alterations in mouse liver, Lab Invest, vol. 92, no. 3, pp. 396-410.

Liebler, D.C. (2008), Protein Damage by Reactive Electrophiles: Targets and Consequences, Chem Res Toxicol, vol. 21, no. 1, pp. 117-128.

Manibusan, M.K., M. Odin and D.A. Eastmond (2007), Postulated carbon tetrachloride mode of action: a review, J Environ Sci Health C Environ Carcinog Ecotoxicol Rev, vol. 25, no. 3, pp.185-209.

Moghe, A. et al. (2015), Molecular mechanisms of acrolein toxicity: relevance to human disease, Toxicol Sci, vol. 143, no. 2, pp. 242-255.

Mohammad, M.K. et al. (2012), Acrolein cytotoxicity in hepatocytes involves endoplasmic reticulum stress, mitochondrial dysfunction and oxidative stress, Toxicol Appl Pharmacol, vol. 265, no. 1, pp. 73-82.

Nardini, M. et al. (2002),Acrolein-induced cytotoxicity in cultured human bronchial epithelial cells. Modulation by alpha-tocopherol and ascorbic acid, Toxicology, vol.170, no. 3, pp. 173-185.

Perrissoud, D. et al. (1980), The effect of carbon tetrachloride on isolated rat hepatocytes, Virchows Archiv $B$, vol. 35, no 1, pp. 83-91.

Pompella, A. et al. (1991), Loss of membrane protein thiols and lipid peroxidation in allyl alcohol hepatotoxicity, Biochemical Pharmacology, vol. 41, no. 8, pp. 255-1259.

Randall, M.J., M. Hristova and A. van der Vliet (2013), Protein alkylation by the $\alpha, \beta$-unsaturated aldehyde acrolein. A reversible mechanism of electrophile signaling? FEBS Lett, vol. 587, no. 23, pp. 38083814.

Reddy, S. et al. (2002), Identification of glutathione modifications by cigarette smoke, Free Radic Biol Med, vol. 33, no.11, pp. 1490-1498.

Roy, J. et al. (2009), Acrolein induces a cellular stress response and triggers mitochondrial apoptosis in A549 cells, Chem Biol Interact, vol. 181, no. 2, pp. 154-167. 
Rudolph, T.K. and B.A. Freeman (2009), Transduction of redox signaling by electrophile-protein reactions, Sci Signal, vol. 2, no. 90, re7.

Schopfer, F.J. et al. (2011), Formation and Signaling Actions of Electrophilic Lipids, Chem Rev, vol. 111, no. 10 , pp. 5997-6021.

Schwend, T. et al. (2008), Alkylation of adenosine deaminase and thioredoxin by acrylamide in human cell cultures, Z Naturforsch, vol. 64, no. 5-6, pp. 447-453.

Tanel, A. et al. (2007), Activation of the death receptor pathway of apoptosis by the aldehyde Acrolein, Free Radic Biol Med, vol. 42, no. 6, pp. 798-810.

Tanel, A. and D.A. Averill-Bates (2005), The aldehyde acrolein induces apoptosis via activation of the mitochondrial pathway, Biochim Biophys Acta, vol. 1743, no. 3, pp. 255-267.

Thompson, C.A. and P.C. Burcham (2008), Protein alkylation, transcriptional responses and cytochrome c release during Acrolein toxicity in A549 cells: influence of nucleophilic culture media constituents, Toxicol In Vitro, vol. 22, no. 4, pp. 844-853.

Zwilling, R. and C. Balduini (eds) (1992), Biology of Aging, vol. 1, Springer Berlin Heidelberg.

\section{Cell death, N/A leads to hepatic macrophages (Kupffer Cells), activation}

\section{How does this Key Event Relationship work}

Damaged hepatocytes release reactive oxygen species (ROS), cytokines such as TGF- $\beta 1$ and TNF- $\alpha$, and chemokines which lead to oxidative stress, inflammatory signalling and finally activation of Kupffer cells (KCs). ROS generation in hepatocytes results from oxidative metabolism by NADH oxidase (NOX) and cytochrome 2E1 activation as well as through lipid peroxidation. Damaged liver cells trigger a sterile inflammatory response with activation of innate immune cells through release of damage-associated molecular patterns (DAMPs), which activate KCs through toll-like receptors and recruit activated neutrophils and monocytes into the liver. Central to this inflammatory response is the promotion of ROS formation by these phagocytes. Upon initiation of apoptosis hepatocytes undergo genomic DNA fragmentation and formation of apoptotic bodies; these apoptotic bodies are consecutively engulfed by $\mathrm{KCs}$ and cause their activation. This increased phagocytic activity strongly up-regulates NOX expression in KCs, a superoxide producing enzyme of phagocytes with profibrogenic activity, as well as nitric oxide synthase (iNOS) mRNA transcriptional levels with consequent harmful reaction between ROS and nitricoxide (NO), like the generation of cytotoxic peroxinitrite (N2O3). ROS and/or diffusible aldehydes also derive from liver sinusoidal endothelial cells (LSECs) which are additional initial triggers of KC activation (Canbay et al., 2004; Jaeschke, 2011; Kisseleva and Brenner, 2008; Kolios et al., 2006; Li et al., 2008; Luckey and Petersen, 2001; Malhi et al., 2010; Orrenius et al., 2011; Poli, 2000; Roberts et al., 2007; Winwood and Arthur, 1993).

Weight of Evidence

Biological plausibility

There is a functional relationship between cell injury/death and $\mathrm{KC}$ activation, consistent with established biological knowledge (Canbay et al., 2004; Jaeschke, 2011; Kisseleva and Brenner, 2008; Kolios et al., 2006; Li et al., 2008; Luckey and Petersen, 2001; Malhi et al., 2010; Orrenius et al., 2011; Poli, 2000; Roberts et al., 2007; Winwood and Arthur, 1993). 


\section{Empirical support for linkage}

There is convincing theoretical evidence that hepatocyte injury and apoptosis causes KC activation, as well as inflammation and oxidative stress. But there are only limited experimental studies which could show that there is a direct relationship between these two events with temporal concordance. Specific markers for activated KCs have not been identified yet. KC activation cannot be detected by staining techniques since cell morphology does not change, but cytokines release can be measured (with the caveat that KCs activate spontaneously in vitro) (LeCluyse et al., 2012; Soldatow et al., 2013). Tukov et al. (2006) examined the effects of KCs cultured in contact with rat hepatocytes. They found that by adding KCs to the cultures they could mimic in vivo drug-induced inflammatory responses. Experiments on cells of the macrophage lineage showed significant aldehyde-induced stimulation of the activity of protein kinase $\mathrm{C}$, an enzyme involved in several signal transduction pathways. Further, 4-Hydroxynonenal (HNE) was demonstrated to up-regulate TGF- $\beta 1$ expression and synthesis in isolated rat KCs. Canbay et al., (2003) could prove that engulfment of hepatocyte apoptotic bodies stimulated KC generation of cytokines.

\section{Uncertainties or inconsistencies}

The detailed mechanisms of the $\mathrm{KC}$ - hepatocyte interaction and its consequences for both normal and toxicant-driven liver responses remain to be determined. $\mathrm{KC}$ activation followed by cytokine release is associated in some cases with evident liver damage, whereas in others this event is unrelated to liver damage or may be even protective; apparently this impact is dependent on the quantity of $\mathrm{KC}$ activation; excessive or prolonged release of $\mathrm{KC}$ mediators can switch an initially protective mechanism to a damaging inflammatory response. Evidence suggests that low levels of cytokine release from KCs constitute a survival signal that protects hepatocytes from cell death and in some cases, stimulates proliferation (Roberts et al., 2007).

Quantitative understanding of the linkage

No quantitative data

Evidence supporting taxonomic applicability

\begin{tabular}{|l|l|l|l|}
\hline \multicolumn{1}{|c|}{ Name } & Scientific name & Evidence & Links \\
\hline human & Homo sapiens & Strong & NCBI \\
\hline Rattus norvegicus & Rattus norvegicus & Strong & NCBI \\
\hline
\end{tabular}

Human; Kolios et al., 2006; Roberts et al., 2007; Winwood and Arthur, 1993.

Rat: Tukov et al., 2006; Roberts et al., 2007.

\section{References}

Canbay, A., S.L. Friedman and G.J. Gores (2004), Apoptosis: the nexus of liver injury and fibrosis, Hepatology, vol. 39, no. 2, pp. 273-278. 
Canbay, A. et al. (2003), Kupffer cell engulfment of apoptotic bodies stimulates death ligand and cytokine expression, Hepatology, vol. 38, no. 5, pp. 1188-1198.

Jaeschke, H. (2011), Reactive oxygen and mechanisms of inflammatory liver injury: Present concepts, $J$ Gastroenterol Hepatol. vol. 26, suppl. 1, pp. 173-179.

Kisseleva T and Brenner DA, (2008), Mechanisms of Fibrogenesis, Exp Biol Med, vol. 233, no. 2, pp. 109122.

Kolios, G., V. Valatas and E. Kouroumalis (2006), Role of Kupffer cells in the pathogenesis of liver disease, World J.Gastroenterol, vol. 12, no. 46, pp. 7413-7420.

LeCluyse, E.L. et al. (2012), Organotypic liver culture models: meeting current challenges in toxicity testing, Crit Rev Toxicol, vol. 42, no. 6, 501-548.

Li, Jing-Ting et al. (2008), Molecular mechanism of hepatic stellate cell activation and antifibrotic therapeutic strategies, J Gastroenterol, vol. 43, no. 6, pp. 419-428.

Luckey, S.W., and D.R. Petersen (2001), Activation of Kupffer cells during the course of carbon tetrachloride-induced liver injury and fibrosis in rats, Exp Mol Pathol, vol. 71, no. 3, pp. 226-240.

Malhi, H. et al. (2010), Hepatocyte death: a clear and present danger, Physiol Rev, vol. 90, no. 3, pp. 11651194.

Orrenius, S., P. Nicotera and B. Zhivotovsky (2011), Cell death mechanisms and their implications in toxicology, Toxicol. Sci, vol. 119, no. 1, pp. 3-19.

Poli, G. (2000), Pathogenesis of liver fibrosis: role of oxidative stress, Mol Aspects Med, vol. 21, no. 3, pp. $49-98$.

Roberts, R.A. et al. (2007), Role of the Kupffer cell in mediating hepatic toxicity and carcinogenesis, Toxicol Sci, vol. 96, no. 1, pp. 2-15.

Soldatow, V.Y. et al. (2013), In vitro models for liver toxicity testing, Toxicol Res, vol. 2, no.1, pp. 23-39.

Tukov, F.F. et al. (2006), Modeling inflammation-drug interactions in vitro: a rat Kupffer cell-hepatocyte co-culture system, Toxicol In Vitro, vol. 20, no. 8, pp. 1488-1499.

Winwood, P.J., and M.J. Arthur (1993), Kupffer cells: their activation and role in animal models of liver injury and human liver disease, Semin Liver Dis, vol. 13, no. 1, pp. 50-59.

\section{Cell death, N/A leads to Stellate cells, activation}

\section{How does this Key Event Relationship work}

Damaged hepatocytes can lead to activation of hepatic stellate cells (HSCs) through the release of ROS, cytokines and chemokines. Engulfment of apoptotic bodies from hepatocytes results in HSC activation and induces NOX (NADPH oxidases) expression in HSCs. DNA from apoptotic hepatocytes induces toll-like receptor 9 (TLR9)-dependent changes of HSCs that are consistent with late stages of HSC differentiation (activation), with up-regulation of collagen production and inhibition of platelet derived growth factor (PDGF)-mediated chemotaxis to retain HSCs at sites of cellular apoptosis. The release of latent TGF-beta complex into the micro-environment by damaged hepatocytes is likely to be one of the first signals for adjacent HSCs leading to their activation (Canbay et al., 2004a; Friedman, 2008; Gressner et al., 2002; Kisseleva and Brenner, 2008; Kolios et al., 2006; Lee and Friedman, 2011; Li et al., 2008; Malhi et al., 2010; Orrenius et al., 2011; Roth et al., 1998).

Damaged hepatocytes also influence liver sinusoidal endothelial cell (LSECs), which make an integral part of the hepatic reticulo-endothelial system and have a role in HSC activation. LSECs 
are morphologically identified by their fenestrations, which are transcytoplasmic canals arranged in sieve plates. In healthy liver, hepatocytes and HSCs maintain this phenotype of LSECs through release of vascular endothelial growth factor (VEGF). Differentiated (i.e. fenestrated) LSECs prevent HSC activation and promote reversal of activated HSC to quiescence, but LSEC lose this effect when they are de-differentiated due to liver injury. Preclinical studies have demonstrated that LSECs undergo defenestration as an early event that not only precedes liver fibrosis, but may also be permissive for it. Changes in LSEC differentiation might be an integral part of the development of fibrosis. Furthermore, in fibrosis LSECs become highly pro-inflammatory and secrete an array of cytokines and chemokines (Connolly et al., 2010; DeLeve, 2013; Ding et al., 2014; Xie et al., 2013; Xie et al., 2012)

This relationship is classified as indirect as HSCs activation is partly mediated by TGF- $\beta 1$ and LSECs.

Weight of Evidence

Biological plausibility

There is a functional relationship between KE 1 and KE 4 consistent with established biological knowledge (Canbay et al., 2004a; Friedman, 2008; Gressner et al., 2002; Kisseleva and Brenner, 2008; Kolios et al., 2006; Lee and Friedman, 2011; Li et al., 2008; Malhi et al., 2010; Orrenius et al., 2011; Roth et al., 1998).

Empirical support for linkage

There is temporal concordance as HSC activation follows hepatic injury and there is experimental evidence for this KER. Canbay et al. (2004b, 2002) could show that Fas-mediated hepatocyte injury is mechanistically linked to liver fibrogenesis. Markers of HSC activation were significantly reduced when apoptosis was prevented in Fas-deficient bile duct ligated mice. These findings (reduction of inflammation, markers of HSC activation, and collagen I expression) could be repeated by pharmacological inhibition of liver cell apoptosis using a pan-caspase inhibitor. Coulouarn et al (2012) found in a co-culture model that hepatocyte - HSC crosstalk engenders a permissive inflammatory micro-environment.

Uncertainties or inconsistencies

There are no inconsistencies

Quantitative understanding of the linkage

There are no quantitative data 
Evidence supporting taxonomic applicability

\begin{tabular}{|l|l|l|l|}
\hline \multicolumn{1}{|c|}{ Name } & Scientific name & Evidence & Links \\
\hline human & Homo sapiens & Strong & NCBI \\
\hline Rattus norvegicus & Rattus norvegicus & Strong & NCBI \\
\hline Mus musculus & Mus musculus & Strong & NCBI \\
\hline
\end{tabular}

Human: Coulouarn et al., 2012; Kisseleva and Brenner, 2008.

Rat: Xie et al., 2012.

Mouse: Canbay et al., 2004b.

\section{References}

Canbay, A., S.L. Friedman and G.J. Gores (2004a), Apoptosis: the nexus of liver injury and fibrosis, Hepatology, vol. 39, no. 2, pp. 273-278.

Canbay, A. et al. (2004b), The caspase inhibitor IDN-6556 attenuates hepatic injury and fibrosis in the bile duct ligated mouse, J Pharmacol Exp Ther, vol. 308, no. 3, pp. 1191-1196.

Canbay, A. et al. (2002), Fas enhances fibrogenesis in the bile duct ligated mouse: a link between apoptosis and fibrosis, Gastroenterology, vol. 123, no. 4, pp. 1323-1330.

Connolly, M.K. et al. (2010), In hepatic fibrosis, liver sinusoidal endothelial cells acquire enhanced immunogenicity, J Immunol, vol. 185, no. 4, pp. 2200-2208.

Coulouarn, C. et al. (2012), Hepatocyte-stellate cell cross-talk in the liver engenders a permissive inflammatory microenvironment that drives progression in hepatocellular carcinoma, Cancer Res, vol. 72, no. 10, pp. 2533-2542.

DeLeve, L.D. (2013), Liver sinusoidal endothelial cells and liver regeneration, J Clin Invest, vol. 123, no. 5, pp. 1861-1866.

Ding, B.S. et al. (2014), Divergent angiocrine signals from vascular niche balance liver regeneration and fibrosis, Nature, vol. 505, no. 7481, pp. 97-102.

Friedman, S.L. (2008), Mechanisms of Hepatic Fibrogenesis, Gastroenterology, vol. 134, no. 6, pp. 16551669.

Gressner, A.M. et al. (2002), Roles of TGF- $\beta$ in hepatic fibrosis. Front Biosci, vol. 7, pp. 793-807.

Kisseleva T and Brenner DA, (2008), Mechanisms of Fibrogenesis, Exp Biol Med, vol. 233, no. 2, pp. 109122.

Kolios, G., V. Valatas and E. Kouroumalis (2006), Role of Kupffer cells in the pathogenesis of liver disease, World J.Gastroenterol, vol. 12, no. 46, pp. 7413-7420.

Lee, U.E. and S.L. Friedman (2011), Mechanisms of Hepatic Fibrogenesis, Best Pract Res Clin Gastroenterol, vol. 25, no. 2, pp. 195-206.

Li, Jing-Ting et al. (2008), Molecular mechanism of hepatic stellate cell activation and antifibrotic therapeutic strategies, J Gastroenterol, vol. 43, no. 6, pp. 419-428.

Malhi, H. et al. (2010), Hepatocyte death: a clear and present danger, Physiol Rev, vol. 90, no. 3, pp. 11651194.

Orrenius, S., P. Nicotera and B. Zhivotovsky (2011), Cell death mechanisms and their implications in toxicology, Toxicol. Sci, vol. 119, no. 1, pp. 3-19. 
Roth, S., K. Michel and A.M. Gressner (1998), (Latent) transforming growth factor beta in liver parenchymal cells, its injury-dependent release, and paracrine effects on rat HSCs, Hepatology, vol. 27, no. 4, pp. 1003-1012.

Xie, G. et al. (2013), Hedgehog signalling regulates liver sinusoidal endothelial cell capillarisation, Gut, vol. 62 , no. 2, pp. 299-309.

Xie, G. et al. (2012), Role of differentiation of liver sinusoidal endothelial cells in progression and regression of hepatic fibrosis in rats, Gastroenterology, vol. 142, no. 4, pp. 918-927.

\section{Hepatic macrophages (Kupffer Cells), activation leads to TGFbeta1 expression, up regulation}

How does this Key Event Relationship work

Following activation Kupffer cells (KCs) become the main source for TGF- $\beta 1$, the most potent profibrogenic cytokine, as well as a major source for inflammatory mediators and for reactive oxygen species (ROS).

Expressed TNF- $\alpha$ (Tumor Necrosis Factor -alpha), TRAIL (TNF-related apoptosis-inducing ligand), and FasL (Fas Ligand) are pro-inflammatory active and also capable of inducing death receptor-mediated apoptosis in hepatocytes.

Activated KCs are an important source of ROS like superoxide (generated by NADPH oxidase (NOX). KCs express TNF- $\alpha$, IL-1 (Interleukin-1) and MCP-1 (monocyte-chemoattractant protein1), all being mitogens and chemoattractants for HSCs and induce the expression of plateletderived growth factor (PDGF) receptors on hepatic stellate cells (HSCs) which further enhances HSCs proliferation (Bataller and Brenner, 2005; Brenner, 2009; Fujiwara and Kobayashi, 2005; Guo and Friedman, 2007; Kamimura and Tsukamoto, 1995; Kirkham, 2007; Kolios et al., 2006; Lee and Friedman, 2011; Li et al., 2008; Reuter et al., 2010).

Weight of Evidence

Biological plausibility

The functional relationship between these KEs is consistent with biological knowledge (Bataller and Brenner, 2005; Brenner, 2009; Fujiwara and Kobayashi, 2005; Guo and Friedman, 2007; Kamimura and Tsukamoto, 1995; Kirkham, 2007; Kolios et al., 2006; Lee and Friedman, 2011; Li et al., 2008; Reuter et al., 2010).

Empirical support for linkage

Cytokine release is one of the features that define $\mathrm{KC}$ activation and there is sound empirical evidence for this KER. Experimental studies have shown enhanced cytokine gene expression by KCs in evolution of experimental liver injury. Northern blot analysis of freshly isolated KCs showed enhanced mRNA expression of three acute phase cytokines by the hepatic resident macrophages, TNF- $\alpha$, IL-6 and TGF- $\beta$ (Chu et al., 2013; De Bleser et al., 1997; Kamimura and Tsukamoto, 1995). Experiments by Matsuoka and Tsukamoto (1990) showed that KCs isolated from rat liver with alcoholic fibrosis express and release TGF- $\beta 1$ and that this cytokine is largely responsible for the $\mathrm{KC}$-conditioned medium-induced stimulation of collagen formation by HSCs. 


\section{Uncertainties or inconsistencies}

There are no inconsistencies

Quantitative understanding of the linkage

No quantitative data

Evidence supporting taxonomic applicability

\begin{tabular}{|l|l|l|l|}
\hline \multicolumn{1}{|c|}{ Name } & Scientific name & Evidence & Links \\
\hline human & Homo sapiens & Strong & NCBI \\
\hline Rattus norvegicus & Rattus norvegicus & Strong & NCBI \\
\hline
\end{tabular}

Human: Bataller and Brenner, 2005; Kolios et al., 2006.

Rat: De Bleser et al.,1997.

\section{References}

Bataller, R. and D.A. Brenner (2005), Liver Fibrosis, J.Clin. Invest, vol. 115, no. 2, pp. 209-218.

Brenner, D.A. (2009), Molecular Pathogenesis of Liver Fibrosis, Trans Am Clin Climatol Assoc, vol. 120, pp. 361-368.

Chu, P.S. et al. (2013), C-C motif chemokine receptor 9 positive macrophages activate hepatic stellate cells and promote liver fibrosis in mice, Hepatology, vol. 58, no. 1, pp. 337-350.

De Bleser, P.J. et al. (1997), Transforming growth factor-beta gene expression in normal and fibrotic rat liver, J Hepatol, vol. 26, no. 4, pp. 886-893.

Fujiwara, N. and K. Kobayashi (2005), Macrophages in inflammation, Curr Drug Targets Inflamm Allergy, vol. 4, no. 3, pp. 281-286.

Guo, J. and S. L. Friedman (2007), Hepatic fibrogenesis, Semin Liver Dis, vol. 27, no. 4, pp. 413-426.

Kamimura, S. and H. Tsukamoto (1995), Cytokine gene expression by Kupffer cells in experimental alcoholic liver disease, Hepatology, vol. 22, no. 4, pp. 1304-1309.

Kirkham, P. (2007), Oxidative stress and macrophage function: a failure to resolve the inflammatory response, Biochem Soc Trans, vol. 35, no. 2, pp. 284-287.

Kolios, G., V. Valatas and E. Kouroumalis (2006), Role of Kupffer cells in the pathogenesis of liver disease, World J.Gastroenterol, vol. 12, no. 46, pp. 7413-7420.

Lee, U.E. and S.L. Friedman (2011), Mechanisms of Hepatic Fibrogenesis, Best Pract Res Clin Gastroenterol, vol. 25, no. 2, pp. 195-206.

$\mathrm{Li}$, Jing-Ting et al. (2008), Molecular mechanism of hepatic stellate cell activation and antifibrotic therapeutic strategies, J Gastroenterol, vol. 43, no. 6, pp. 419-428.

Matsuoka, M. and H. Tsukamoto, (1990), Stimulation of hepatic lipocyte collagen production by Kupffer cell-derived transforming growth factor beta: implication for a pathogenetic role in alcoholic liver fibrogenesis, Hepatology, vol. 11, no. 4, pp. 599-605.

Reuter, S. et al. (2010), Oxidative stress, inflammation, and cancer: how are they linked? Free Radic Biol Med, vol. 49, no. 11, pp. 1603-1616. 


\title{
5. TGF beta1 expression, up regulation leads to Stellate cells, activation
}

\author{
How does this Key Event Relationship work
}

Transforming growth factor beta 1 (TGF- $\beta 1)$ is the most potent fibrogenic factor for epatic stellate cells (HSCs). In response to TGF- $\beta 1$, HSCs activate into myofibroblast-like cells, producing type I, III and IV collagen, proteoglycans like biglycan and decorin, glycoproteins like laminin, fibronectin, tenascin and glycosaminoglycan (Kisseleva and Brenner, 2007). In the further course of events activated HSCs themselves express TGF- $\beta 1$. TGF- $\beta 1$ induces its own mRNA to sustain high levels in local sites of liver injury. The effects of TGF- $\beta 1$ are mediated by intracellular signalling via Smad proteins. Smads 2 and 3 are stimulatory whereas Smad 7 is inhibitory. Smad1/5/8, MAP kinase and PI3 kinase are further signalling pathways in different cell types for TGF- $\beta 1$ effects (Parsons et al., 2007). Concomitant with increased TGF- $\beta$ production, HSC increase production of collagen. Connective tissue growth factor (CTGF) is a profibrogenic peptide induced by TGF- $\beta$, that stimulates the synthesis of collagen type I and fibronectin and may mediate some of the downstream effects of TGF- $\beta$. It is upregulated during activation of HSC, suggesting that its expression is another determinant of a fibrogenic response to TGF- $\beta$ (Williams et al., 2000). During fibrogenesis, tissue and blood levels of active TGF- $\beta$ are elevated and overexpression of TGF- $\beta 1$ in transgenic mice can induce fibrosis. Additionally, experimental fibrosis can be inhibited by anti-TGF- $\beta$ treatments with neutralising antibodies or soluble TbRs (TGF- $\beta$ receptors) (Qi et al., 1999).

Weight of Evidence

\section{Biological plausibility}

There is good understanding and broad acceptance of this KER (Bataller and Brenner, 2005; Brenner, 2009; Friedman, 2008; Gressner et al., 2002; Guo and Friedman, 2007; Kaimori et al., 2007; Kershenobich Stalnikowitz and Weissbrod, 2003; Kisseleva and Brenner, 2008; Kisseleva and Brenner, 2007; Kolios et al., 2006; Li et al., 2008; Liu et al., 2006; Matsuoka and Tsukamoto, 1990; Parsons et al., 2007; Poli, 2000; Qi et al., 1999; Williams et al., 2000).

\section{Empirical support for linkage}

It is difficult to get experimental evidence in vitro for TGF- $\beta 1$-induced HSC activation because HSCs undergo spontaneous activation when cultured on plastic; nevertheless qualitative empirical evidence for temporal and incidence concordance for this KER exists. Czaja et al. (1989) could prove that treatment of cultured hepatic cells with TGF- $\beta 1$ increased type I pro-collagen mRNA levels 13-fold due to post-transcriptional gene regulation. Tan et al. (2013) discovered that short TGF- $\beta 1$ pulses can exert long-lasting effects on fibroblasts. HSCs activated in culture do not fully reproduce the changes in gene expression observed in vivo. De Minicis et al. (2007) investigated gene expression changes in 3 different models of HSC activation and compared gene expression profiles in culture (mice HSCs in co-culture with $\mathrm{KCs}$ ) and in vivo and did not find a proper correlation (Tan et al., 2013; Yin et al., 2013).

Uncertainties or inconsistencies

There are no uncertainties that TGF- $\beta 1$ activates HSCs. 
Quantitative understanding of the linkage

No quantitative data

Evidence supporting taxonomic applicability

\begin{tabular}{|l|l|l|l|}
\hline \multicolumn{1}{|c|}{ Name } & \multicolumn{1}{|c|}{ Scientific name } & Evidence & Links \\
\hline human & Homo sapiens & Strong & NCBI \\
\hline Rattus norvegicus & Rattus norvegicus & Strong & NCBI \\
\hline
\end{tabular}

Human: Guo and Friedman; 2007; Kolios et al., 2006.

Rat: Dooley et al., 2000.

\section{References}

Bataller, R. and D.A. Brenner (2005), Liver Fibrosis, J.Clin. Invest, vol. 115, no. 2, pp. 209-218.

Brenner, D.A. (2009), Molecular Pathogenesis of Liver Fibrosis, Trans Am Clin Climatol Assoc, vol. 120, pp. 361-368.

Czaja, M.J. et al. (1989), In vitro and in vivo association of transforming growth factor-beta 1 with hepatic fibrosis, J Cell Biol, vol. 108, no. 6, pp. 2477-2482.

De Minicis, S. et al. (2007), Gene expression profiles during hepatic stellate cell activation in culture and in vivo, Gastroenterology, vol. 132, no. 5, pp. 1937-1946.

Dooley, S. et al. (2000), Modulation of transforming growth factor b response and signaling during transdifferentiation of rat hepatic stellate cells to myofibroblasts, Hepatology, vol. 31, no. 5, pp. 1094-1106.

Friedman, S.L. (2008), Mechanisms of Hepatic Fibrogenesis, Gastroenterology, vol. 134, no. 6, pp. 16551669.

Gressner, A.M. et al. (2002), Roles of TGF- $\beta$ in hepatic fibrosis. Front Biosci, vol. 7, pp. 793-807.

Guo, J. and S. L. Friedman (2007), Hepatic fibrogenesis, Semin Liver Dis, vol. 27, no. 4, pp. 413-426.

Kaimori, A. et al. (2007), Transforming growth factor-betal induces an epithelial-to-mesenchymal transition state in mouse hepatocytes in vitro, J Biol Chem, vol. 282, no. 30, pp. 22089-22101.

Kershenobich Stalnikowitz, D. and A.B. Weisssbrod (2003), Liver Fibrosis and Inflammation. A Review, Annals of Hepatology, vol. 2, no. 4, pp.159-163.

Kisseleva T and Brenner DA, (2008), Mechanisms of Fibrogenesis, Exp Biol Med, vol. 233, no. 2, pp. 109122.

Kisseleva, T. and Brenner, D.A. (2007), Role of hepatic stellate cells in fibrogenesis and the reversal of fibrosis, Journal of Gastroenterology and Hepatology, vol. 22, Suppl. 1; pp. S73-S78.

Kolios, G., V. Valatas and E. Kouroumalis (2006), Role of Kupffer cells in the pathogenesis of liver disease, World J.Gastroenterol, vol. 12, no. 46, pp. 7413-7420.

$\mathrm{Li}$, Jing-Ting et al. (2008), Molecular mechanism of hepatic stellate cell activation and antifibrotic therapeutic strategies, J Gastroenterol, vol. 43, no. 6, pp. 419-428.

Liu, Xingjun et al. (2006), Therapeutic strategies against TGF-beta signaling pathway in hepatic fibrosis. Liver Int, vol.26, no.1, pp. 8-22. 
Matsuoka, M. and H. Tsukamoto, (1990), Stimulation of hepatic lipocyte collagen production by Kupffer cell-derived transforming growth factor beta: implication for a pathogenetic role in alcoholic liver fibrogenesis, Hepatology, vol. 11, no. 4, pp. 599-605.

Parsons, C.J., M.Takashima and R.A. Rippe (2007), Molecular mechanisms of hepatic fibrogenesis. $J$ Gastroenterol Hepatol, vol. 22, Suppl.1, pp. S79-S84.

Poli, G. (2000), Pathogenesis of liver fibrosis: role of oxidative stress, Mol Aspects Med, vol. 21, no. 3, pp. 49-98.

Qi Z et al. (1999), Blockade of type beta transforming growth factor signaling prevents liver fibrosis and dysfunction in the rat, Proc Natl Acad Sci USA, vol. 96, no. 5, pp. 2345-2349.

Tan, A.B. et al. (2013), Cellular re- and de-programming by microenvironmental memory: why short TGF$\beta 1$ pulses can have long effects, Fibrogenesis Tissue Repair, vol. 6, no. 1, p. 12.

Williams, E.J. et al. (2000), Increased expression of connective tissue growth factor infibrotic human liver and in activated hepatic stellate cells, J Hepatol, vol. 32, no. 5, pp. 754-761.

Yin, C. et al. (2013), Hepatic stellate cells in liver development, regeneration, and cancer, J Clin Invest, vol. 123 , no. 5, pp. 1902-1910.

\section{Stellate cells, activation leads to collagen, accumulation}

\section{How does this Key Event Relationship work}

Up-regulation of collagen synthesis following hepatic stellate cell (HSC) activation is among the most striking molecular responses of HSCs to injury and is mediated by both transcriptional and post-transcriptional mechanisms. Activated HSCs do not only proliferate and increase cell number, but also increase collagen production per cell. Synthesis of type I collagen is initiated by expression of the colla1 and colla2 genes, giving rise to $\alpha 1$ (I) and $\alpha 2$ (I) procollagen mRNAs in a 2:1 ratio. Upon activation of HSCs and other myofibroblast precursors, there is a $>50$-fold increase in $\alpha 1$ (I) procollagen mRNA levels. The half-life of collagen $\alpha 1$ (I) mRNA increases 20fold in activated HSCs compared with quiescent HSCs. Monocytes and macrophages are involved in inflammatory actions by producing large amounts of Nitric oxide (NO) and inflammatory cytokines such as TNF- $\alpha$ which have a direct stimulatory effect on HSC collagen synthesis. Synthesis of TGF- $\alpha$ and TGF- $\beta$ promotes activation of neighbouring quiescent HSCs, whereas the release of HGF (hepatocyte growth factor) stimulates regeneration of adjacent hepatocytes.

The basement membrane-like matrix is normally comprised of collagens IV and VI, which is progressively replaced by collagens I and III and cellular fibronectin during fibrogenesis. Although multiple extracellular matrix (ECM) components are up-regulated, type I collagen is the most abundant protein. These changes in ECM composition initiate several positive feedback pathways that further amplify collagen production. Increasing matrix stiffness is a stimulus for HSC activation and matrix-provoked signals link to other growth factor receptors through integrin-linked kinase and transduce via membrane-bound guanosine triphosphate binding proteins, in particular Rho67 and Rac, signals to the actin cytoskeleton that promote migration and contraction.

The overall amount of collagen deposited by fibroblasts is a regulated balance between collagen synthesis and collagen catabolism. Down-regulated expression of degrading Matrix metalloproteinases (MMPs) and up-regulation of tissue inhibitors of metalloproteinases (TIMPs), MMP- inhibitors, lead to a net decrease in protease activity, and therefore, matrix accumulation. 
Chronic inflammation, hypoxia and oxidative stress reactivate epithelial-mesenchymal transition (EMT) developmental programmes that converge in the activation of NF-kB. Cells that may transdifferentiate into fibrogenic myofibroblasts are hepatocytes and cholangiocytes. Additional sources of ECM include bone marrow (which probably gives rise to circulating fibrocytes) and portal fibroblasts (Bataller and Brenner, 2005; Benyon and Arthur, 2001; Brenner, 2009; Chen and Raghunath, 2009; Dalton et al., 2009; Friedman, 2010; Friedman, 2008; Guo and Friedman, 2007; Hamdy and El-Demerdash, 2012; Henderson and Iredale, 2007; Kershenobich Stalnikowitz and Weissbrod, 2003; Kolios et al., 2006; Lee and Friedman, 2011; Leung et al., 2008; Li L. et al., 2012; Li J.T. et al., 2008; López-Novoa and Nieto, 2009; Luckey and Petersen, 2001; Milani et al., 1994; Nan et al., 2013; Natarajan et al., 2006; Safadi and Friedman, 2002; Thompson et al., 2011).

\section{Weight of Evidence}

\section{Biological plausibility}

There is general acceptance that HSCs are collagen producing cells and key actors in fibrogenesis. The functional relationship between these KEs is consistent with biological knowledge (Bataller and Brenner, 2005; Benyon and Arthur, 2001; Brenner, 2009; Guo and Friedman, 2007; Kershenobich Stalnikowitz and Weissbrod, 2003; Kolios et al., 2006; Lee and Friedman, 2011; Li et al., 2008; López-Novoa and Nieto, 2009; Milani et al., 1994; Safadi and Friedman, 2002).

\section{Empirical support for linkage}

It is difficult to stimulate sufficient collagen production and its subsequent incorporation into a pericellular matrix in vitro; therefore analytical methods have focused on measurement of procollagen secreted into culture medium or measurement of $\alpha$-smooth muscle actin ( $\alpha$-SMA) expression, a marker of fibroblast activation. In primary culture, HSCs from normal liver begin to express $\alpha$-SMA coincident with culture-induced activation (Chen and Raghunath, 2009; Rockey et al., 1992).

\section{Uncertainties or inconsistencies}

No inconsistencies

Quantitative understanding of the linkage

No quantitative data

Evidence supporting taxonomic applicability

\begin{tabular}{|l|l|l|l|}
\hline \multicolumn{1}{|c|}{ Name } & Scientific name & Evidence & Links \\
\hline human & Homo sapiens & Strong & NCBI \\
\hline Rattus norvegicus & Rattus norvegicus & Strong & NCBI \\
\hline
\end{tabular}

Human: Bataller and Brenner, 2005; Lee and Friedman, 2011; Safadi and Friedman, 2002.

Rat: Li et al., 2012; Luckey and Petersen, 2001; Rockey et al., 1992. 


\section{References}

Bataller, R. and D.A. Brenner (2005), Liver Fibrosis, J.Clin. Invest, vol. 115, no. 2, pp. 209-218.

Benyon, R.C. and M.J. Arthur (2001), Extracellular matrix degradation and the role of stellate cells, Semin Liver Dis, vol. 21, no. 3, pp. 373-384.

Brenner, D.A. (2009), Molecular Pathogenesis of Liver Fibrosis, Trans Am Clin Climatol Assoc, vol. 120, pp. 361-368.

Chen, C. and M. Raghunath (2009), Focus on collagen: in vitro systems to study fibrogenesis and antifibrosis state of the art, Fibrogenesis Tissue Repair, vol. 15, no. 2, p. 7.

Dalton, S.R. et al. (2009), Carbon tetrachloride-induced liver damage in asialoglycoprotein receptordeficient mice, Biochem Pharmacol, vol. 77, no. 7, pp. 1283-1290.

Friedman, S.L (2010), Evolving challenges in hepatic fibrosis, Nat. Rev. Gastroenterol. Hepatol, vol. 7, no. 8, pp. $425-436$.

Friedman, S.L. (2008), Mechanisms of Hepatic Fibrogenesis, Gastroenterology, vol. 134, no. 6, pp. 16551669.

Guo, J. and S. L. Friedman (2007), Hepatic fibrogenesis, Semin Liver Dis, vol. 27, no. 4, pp. 413-426.

Hamdy, N. and E. El-Demerdash. (2012), New therapeutic aspect for carvedilol: antifibrotic effects of carvedilol in chronic carbon tetrachloride-induced liver damage, Toxicol Appl Pharmacol, vol. 261, no. 3, pp. 292-299.

Henderson, N.C. and J.P. Iredale (2007), Liver fibrosis: cellular mechanisms of progression and resolution, Clin Sci (Lond), vol. 112, no. 5, pp. 265-280.

Kershenobich Stalnikowitz, D. and A.B. Weisssbrod (2003), Liver Fibrosis and Inflammation. A Review, Annals of Hepatology, vol. 2, no. 4, pp.159-163.

Kolios, G., V. Valatas and E. Kouroumalis (2006), Role of Kupffer cells in the pathogenesis of liver disease, World J.Gastroenterol, vol. 12, no. 46, pp. 7413-7420.

Lee, U.E. and S.L. Friedman (2011), Mechanisms of Hepatic Fibrogenesis, Best Pract Res Clin Gastroenterol, vol. 25, no. 2, pp. 195-206.

Leung, T.M. et al. (2008), Endothelial nitric oxide synthase is a critical factor in experimental liver fibrosis, Int J Exp Pathol, vol. 89, no. 4, pp. 241-250.

$\mathrm{Li}$, Jing-Ting et al. (2008), Molecular mechanism of hepatic stellate cell activation and antifibrotic therapeutic strategies, J Gastroenterol, vol. 43, no. 6, pp. 419-428.

Li, Li et al. (2012), Establishment of a standardized liver fibrosis model with different pathological stages in rats, Gastroenterol Res Pract; vol. 2012, Article ID 560345.

López-Novoa, J.M. and M.A. Nieto (2009), Inflammation and EMT: an alliance towards organ fibrosis and cancer progression, EMBO Mol Med, vol. 1. no. 6-7, pp. 303-314.

Luckey, S.W., and D.R. Petersen (2001), Activation of Kupffer cells during the course of carbon tetrachloride-induced liver injury and fibrosis in rats, Exp Mol Pathol, vol. 71, no. 3, pp. 226-240.

Milani, S. et al. (1994), Differential expression of matrix-metalloproteinase-1 and -2 genes in normal and fibrotic human liver, Am J Pathol, vol. 144, no. 3, pp. 528-537.

Nan, Y.M. et al. (2013), Activation of peroxisome proliferator activated receptor alpha ameliorates ethanol mediated liver fibrosis in mice, Lipids in Health and Disease, vol. 12, p. 11.

Natajaran, S.K. et al. (2006), Oxidative stress in the development of liver cirrhosis: a comparison of two different experimental models, J Gastroenterol Hepatol, vol. 21, no. 6, pp. 947-957.

Rockey, D.C. et al. (1992), Rat hepatic lipocytes express smooth muscle actin upon activation in vivo and in culture, J Submicrosc Cytol Pathol, vol. 24, no. 2, pp. 193-203. 
Safadi, R. and S.L. Friedman (2002), Hepatic fibrosis--role of hepatic stellate cell activation, MedGenMed, vol 4, no. 3, p. 27.

Thompson, K.J., I.H. McKillop and L.W. Schrum (2011), Targeting collagen expression in alcoholic liver disease, World J Gastroenterol, vol. 17, no. 20, pp. 2473-2481.

\section{Collagen, accumulation leads to liver fibrosis, N/A}

How does this Key Event Relationship work

Liver fibrosis is the excessive accumulation of extracellular matrix (ECM) proteins including collagen. Liver fibrosis results from an imbalance between the deposition and degradation of ECM and a change of ECM composition; the latter initiates several positive feedback pathways that further amplify fibrosis. With chronic injury, there is progressive substitution of the liver parenchyma by scar tissue. Deposition of collagen in the liver progressively disrupts the normal hepatic architecture so that the normal relationship between vascular inflow and outflow is destroyed and the normal collagen content around hepatic sinusoids in regenerating nodules becomes modified. Advanced liver fibrosis results in cirrhosis (Bataller and Brenner, 2005; Brancatelli et al., 2009; Lee und Friedmann, 2011; Pellicoro et al., 2014; Poynard et al., 1997; Rockey et al., 2006).

Weight of Evidence

\section{Biological plausibility}

By definition, liver fibrosis is the excessive accumulation of ECM proteins that are produced by HSCs. The KER between this KE and the AO is undisputed (Bataller and Brenner, 2005; Brancatelli et al., 2009; Lee and Friedman, 2011; Poynard et al., 1997; Rockey et al., 2006).

Empirical support for linkage

There is a smooth transition from ECM accumulation to liver fibrosis without a definite threshold and plenty in vivo evidence exists that ECM accumulation is a pre-stage of liver fibrosis (Bataller and Brenner, 2005; Brancatelli et al., 2009; Lee and Friedman, 2011; Poynard et al., 1997; Rockey et al., 2006).

Uncertainties or inconsistencies

No inconsistencies

Quantitative understanding of the linkage

No quantitative data 
Evidence supporting taxonomic applicability

\begin{tabular}{|l|l|l|l|}
\hline \multicolumn{1}{|c|}{ Name } & Scientific name & Evidence & Links \\
\hline human & Homo sapiens & Strong & NCBI \\
\hline Rattus norvegicus & Rattus norvegicus & Strong & NCBI \\
\hline
\end{tabular}

Human: Bataller and Brenner, 2005; Brancatelli et al., 2009; Lee and Friedman, 2011; Poynard et al., 1997; Rockey et al., 2006.

Rat: Liedtke et al., 2013

\section{References}

Bataller, R. and D.A. Brenner (2005), Liver Fibrosis, J.Clin. Invest, vol. 115, no. 2, pp. 209-218.

Brancatelli, G. et al. (2009), Focal confluent fibrosis in cirrhotic liver: natural history studied with serial CT, AJR Am J Roentgenol, vol. 192, no. 5, pp. 1341-1347.

Lee, U.E. and S.L. Friedman (2011), Mechanisms of Hepatic Fibrogenesis, Best Pract Res Clin Gastroenterol, vol. 25, no. 2, pp. 195-206.

Liedtke, C. et al. (2013), Experimental liver fibrosis research: update on animal models, legal issues and translational aspects, Fibrogenesis Tissue Repair, vol. 6, no. 1, p. 19.

Pellicoro, A. et al. (2014), Liver fibrosis and repair: immune regulation of wound healing in a solid organ, Nat Rev Immunol, vol. 14, no. 3, pp. 181-194.

Poynard, T., P. Bedossa and P. Opolon (1997), Natural history of liver fibrosis progression in patients with chronic hepatitis C. The OBSVIRC, METAVIR, CLINIVIR, and DOSVIRC groups, Lancet, vol. 349, no. 9055, pp. 825-832.

Rockey, D.C. and S.L. Friedman (2006), Hepatic fibrosis and cirrhosis, Zakim and Boyer's Hepatology, 5th edition, section 1, chapter 6, pp. 87-109.

\section{Overall assessment of the AOP}

\section{Assessment of the Weight-of-Evidence supporting the AOP}

\section{Concordance of dose-response relationships}

This is a qualitative description of the pathway; the currently available literature does not provide quantitative information on dose-response relationships. But there is empirical evidence to support that a change in KEup leads to an appropriate change in the respective KEdown.

Temporal concordance among the key events and adverse outcome

Empirical evidence shows temporal concordance between the individual KEs leading to the AO. 
Strength, consistency, and specificity of association of adverse outcome and initiating event

The scientific evidence on the linkage between MIE and AO has been described. The ample literature is consistent in describing this association between AO and MIE

Biological plausibility, coherence, and consistency of the experimental evidence

The available data supporting the AOP are logic, coherent and consistent with established biological knowledge.

Alternative mechanism(s) that logically present themselves and the extent to which they may distract from the postulated $A O P$

There are some other important fibrogenic signalling pathways that influence HSC activation and fibrogenesis without constituting another AOP:

Adipokine pathways

Adipokines are secreted mainly by adipose tissue, but also by resident and infiltrating macrophages and are increasingly recognised as mediators of fibrogenesis.

Leptin promotes HSC fibrogenesis and enhances TIMP-1 expression and further acts as a profibrotic through suppression of peroxisome proliferator-activated receptor-gamma (PPAR $\gamma$ ), an anti-fibrogenic nuclear receptor that can reverse HSC activation. The expression of leptin receptor is up-regulated during HSC activation and leptin activity is therefore increased through enhanced signalling. Downstream effects include increased release of TGF- $\beta 1$ from KCs. The counterregulatory hormone adiponectin is reduced in hepatic fibrosis (Friedman, 2010; Lee and Friedman, 2011).

\section{Neuroendocrine pathways}

The fibrogenic function of HSCs is also influenced by neurochemical and neurotrophic factors. Upon chronic liver injury, the local neuroendocrine system is up-regulated, and activated HSCs express specific receptors, most prominently those regulating cannabinoid signalling. Activated HSCs are additionally a key source of the endogenous cannabinoid,2-Arachidonylglycerol (2AG), which drives increased (cannabinoid-receptor) CB 1 signalling. Stimulation of the CB1 receptor is profibrogenic, whereas the CB2 receptor is anti-fibrotic and hepatoprotective. Opioid signalling increases proliferation and collagen production in HSCs. Serotonin has a pro-fibrotic effect that synergises with PDGF signalling. Also thyroid hormones enhance activation of HSCs (through increased p75 neurotrophin receptor (p75NTR) and activation of Rho), thereby accelerating the development of liver fibrosis (Friedman, 2010; 2008 Lee and Friedman, 2011).

\section{Renin-angiotensin pathway}

Angiotensin II (Ang II) is a pro-oxidant and fibrogenic cytokine that stimulates DNA synthesis, cell migration, procollagen $\alpha 1$ (I) mRNA expression, and secretion of TGF- $\beta 1$ and inflammatory cytokines. These fibrogenic actions are mediated by NOX (Bataller et al., 2003; Friedman, 2010; Kisseleva and Brenner, 2008; Lee and Friedman, 2011). 
This AOP description is plausible, though purely qualitative; the addition of quantitative data on dose response-relationships and temporal sequences would substantially improve its applicability. Protein alkylation is a broad, non-specific MIE. Covalent protein alkylation is a feature of many hepatotoxic drugs but the overall extent of binding does not adequately distinguish toxic from non-toxic binding. For this AOP it is unclear whether protein alkylation per se is sufficient to start the pathway or whether alkylation to specific proteins or families of proteins needs to be affected and whether various binding sites influence the further downstream process. The identification and specification of the targeted biomolecules is needed for the structural definition of chemical initiators and consecutively for profiling and categorising of chemicals related to the initiation of this AOP. Likewise it is necessary for the establishment of a distinct relationship with the next downstream event. Further it is unknown whether there is a threshold and if this threshold would refer to the number of alkylation of a single protein or of a threshold number of proteins. Future studies could provide a better mechanistic basis for interpreting protein alkylation in chemical safety evaluation.

By definition, an AOP has only one MIE and one final AO, the two anchor points of the AOP that have to be clearly defined. Any other MIE that leads to cell injury and further to liver fibrosis via the same downstream KEs would constitute another AOP. There are various types of liver injury that are caused by different agents, initiated by various MIEs and finally lead to fibrosis via the same described pathway; therefore, the question arises whether hepatocyte injury itself, independently from the cause of injury, might be the initiating event for this pathway to fibrosis. Obviously hepatocyte injury does not inevitably lead to fibrosis in all cases and there is a wide range of hepatotoxic chemicals (like Acetaminophen, Aflatoxin or Chlorpromazine) for which liver fibrosis cannot be observed. Apoptosis, necrosis, transdifferentiation/transition and repair/regeneration, all these might occur in response to cellular stressors and the difference in progression to liver fibrosis might lie in these various cellular responses. There is increasing evidence for apoptosis being the main fibrogenic trigger. Yet, both necrosis and apoptosis are often present simultaneously and necrosis may only represent the more severe cellular response to stronger damaging stimuli. It also might well be that hepatocyte insult/injury, rather than death is sufficient to trigger fibrosis and the key question would then be whether there are fibrosis-specific features of cell injury. It could be rather the amount (quantitative difference) than the kind (qualitative difference) of cell injury that matters. The rate of cell injury/death, i.e. the amount of injury within a certain time frame could be another plausible initiating parameter, as fibrosis is resulting from chronic injury. Assuming hepatocyte injury being the crucial KE without which fibrosis could not occur via this AOP, then simple investigation of in vitro hepatotoxicity could provide relevant information for potential fibrosis prediction without the need of highly elaborated cell models.

The initial AOP case study was based on data of two prototypic fibrogenic chemicals, namely Carbon Tetrachloride (CCl4) (Basu, 2003; Brattin et al., 1985; Calabrese and Mehendale, 1996; Calabrese et al., 1993; Clawson, 1989: Dalton et al., 2009; Dalu and Mehendale, 1996; EPA, 2010; Feng et al., 2011; Hamdy and El-Demerdash, 2012; Jaeschke et al., 2013; Jang et al., 2008; Knockaert et al., 2012; Lee et al., 2004; Leung et al., 2008; Li L. et al., 2012; Li X. et al., 2013; Luckey and Petersen, 2001; Luster et al., 2000; 2001; Lv et al., 2012; Manibusan et al., 2007; Masuda, 2006; Morio et al., 2001; Nagano et al., 2007; Nan et al., 2013; Natajaran et al., 2006; Natsume et al., 1999; Neubauer et al., 1998; Nissar et al.,2013;Park et al., 2004; Recknagel, 1976; Simeonova et al., 2001; Tipoe et al., 2006;Weber et al., 2003; Zhu and Fung, 2000) and Allyl 
Alcohol (Auerbach et al., 2008; Huang et al., 2008; Jung et al., 2000; Kehrer and Biswal, 2000; Mohammad et al., 2012; Yamada et al., 2013). Further knowledge was gathered by looking for mechanistic data of other chemicals which are known inducers of liver fibrosis, namely Thioacetamide (Akhtar and Nadeem Sheikh, 2013; Altomonte et al., 2013; Amin al., 2013; Chilakapati et al., 2005; Hajovsky et al., 2012; Ide et al., 2003; Ide et al., 2005; Kang, 2008; Kim et al., 2013; Ledda-Columbano et al., 1991; Low et al., 2004; Nafees et al., 2013; Natajaran et al., 2006; Sarma et al., 2012; Shirai et al., 2013; Staňková et al., 2010; Sun et al., 2000; Waters et al., 2005), Amiodarone (Cimic and Sirintrapun, 2013; Felser et al., 2013; Golli-Bennour et al., 2012; Isomoto et al., 2004; Kicker et al., 2012; Lu et al., 2013: Nasser et al., 2013), Methotrexate (AlAli et al., 2005; Al-Motabagani, 2006; Belinsky et al., 2007; Fathi et al., 2002; Hall et al., 1991; Hytiroglou et al., 2004; Lindsay K et al., 2009), Isoniazid (Bhadauria et al., 2007; Schwab and Tuschl, 2003; Singh et al., 2010; Tostmann et al., 2008), Dimethyl Nitrosamine (George et al., 2003; George, 2001; Ju et al., 2013; Usunomena et al., 2012), Ethanol (Das et al., 2010; Friedman, 1999; Nan et al., 2013; Purohit and Brenner, 2006; Siegmund et al., 2005; Thompson et al., 2011; Wang et al., 2006), Retinol (Castano et al., 2006; Levine et al., 2003; Nollevaux M. et al., 2006), Ethinyl Estradiol (Pandey et al., 2011; Pandey et al., 2010; Radzikowska et al., 2012), and Chlopromazine (Antherieu et al., 2013; Parmentier et al., 2013; Wen and Zhou, 2009).

Mechanistic data related to these additional chemicals are rather scarce, because classical in vivo studies were mainly looking at the AO than at intermediate (key) events and in vitro studies investigating liver fibrosis tend to use always the same reference chemicals. The overall gathered information was summarised in a data matrix that displays how many (if any) individual studies have observed the same findings at the MIE, KE and AO levels. Blue boxes refer to the KEs described in this AOP to liver fibrosis and green boxes indicate the observation of the event (the number within the box showing how many individual publications reported this specific event). It must be noted that these studies have not intended to investigate KEs on various levels of biological information; therefore, absence of a KE description does not necessarily mean that this KE did not occur, but rather that it has not been investigated or described. This matrix shows that protein binding was indicated as MIE only for three more chemicals Thioacetamide, Retinol and Dimethylnitrosamine) and therefore only these were added to the list of chemical initiators of this AOP. This matrix also demonstrates that hepatocyte injury/death is an early convergent $\mathrm{KE}$ that is valid for all described fibrogenic chemicals. 


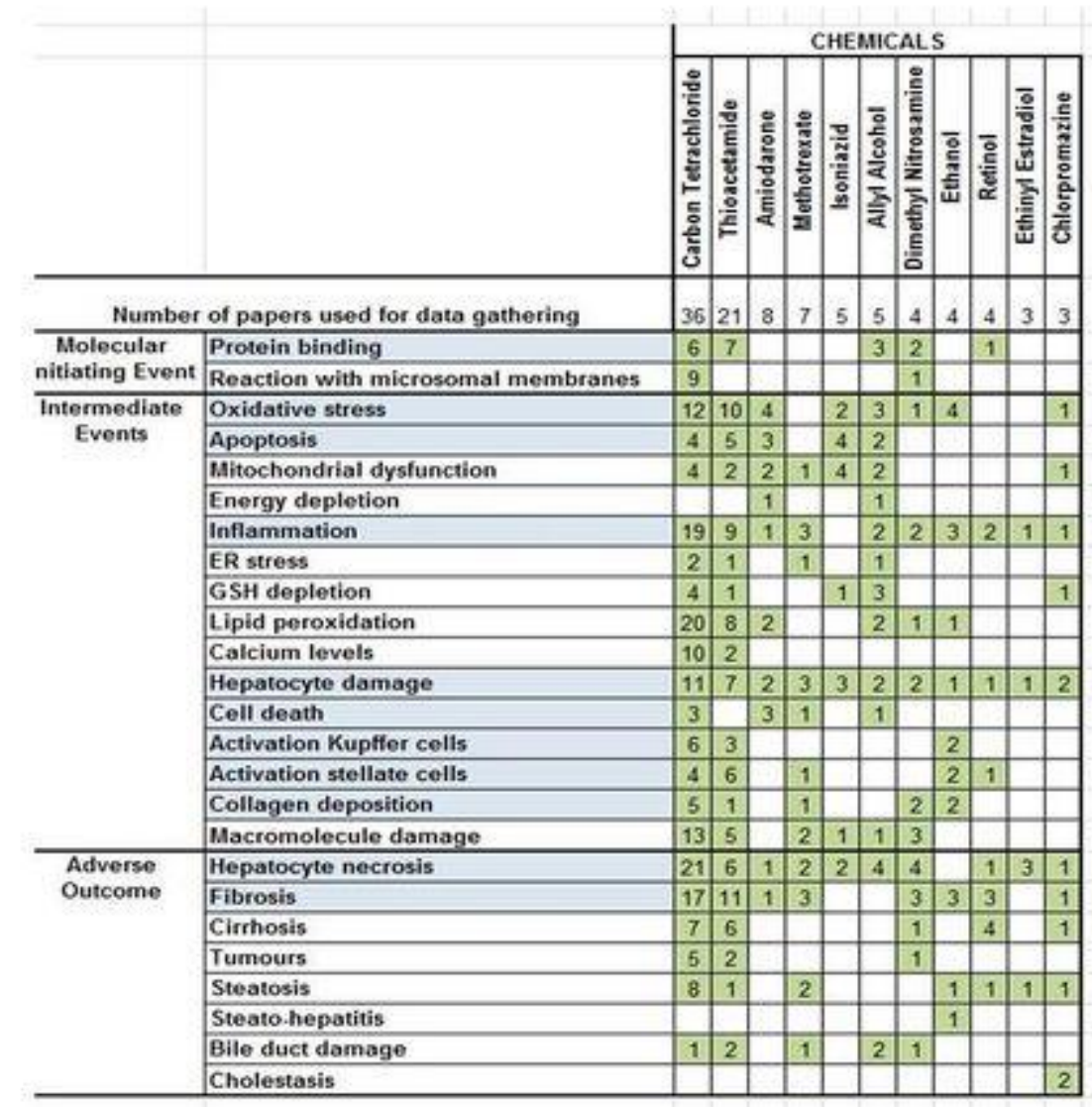

Assessment of the quantitative understanding of the AOP

See above

Weight of Evidence Summary

\begin{tabular}{|c|c|c|c|}
\hline Event & Description & Triggers & $\begin{array}{l}\text { Weight of } \\
\text { Evidence }\end{array}$ \\
\hline Protein, alkylation & $\begin{array}{l}\text { Directly leads } \\
\text { to }\end{array}$ & Cell death, N/A & Moderate \\
\hline Cell death, N/A & $\begin{array}{l}\text { Directly leads } \\
\text { to }\end{array}$ & $\begin{array}{l}\text { Hepatic macrophages (Kupffer } \\
\text { Cells), activation }\end{array}$ & Strong \\
\hline Cell death, N/A & $\begin{array}{l}\text { Indirectly leads } \\
\text { to }\end{array}$ & Stellate cells, activation & Strong \\
\hline $\begin{array}{l}\text { Hepatic macrophages (Kupffer } \\
\text { Cells), activation }\end{array}$ & $\begin{array}{l}\text { Directly leads } \\
\text { to }\end{array}$ & $\begin{array}{l}\text { TGFbeta1 expression, up } \\
\text { regulation }\end{array}$ & Strong \\
\hline $\begin{array}{l}\text { TGFbeta1 expression, up } \\
\text { regulation }\end{array}$ & $\begin{array}{l}\text { Directly leads } \\
\text { to }\end{array}$ & Stellate cells, activation & Strong \\
\hline
\end{tabular}




\begin{tabular}{|l|l|l|l|}
\hline \multicolumn{1}{|c|}{ Event } & Description & \multicolumn{1}{c|}{ Triggers } & \multicolumn{1}{c|}{$\begin{array}{c}\text { Weight of } \\
\text { Evidence }\end{array}$} \\
\hline Stellate cells, activation & $\begin{array}{l}\text { Directly leads } \\
\text { to }\end{array}$ & Collagen, accumulation & Strong \\
\hline Collagen, accumulation & $\begin{array}{l}\text { Directly leads } \\
\text { to }\end{array}$ & Liver fibrosis, N/A & Strong \\
\hline
\end{tabular}

\section{Summary Table}

This table provides an overall summary of the weight of evidence based on the evaluations of the individual linkages from the Key Event Relationship section.

\begin{tabular}{|c|c|c|}
\hline \multicolumn{3}{|c|}{ Support for Essentiality of KEs } \\
\hline $\begin{array}{l}\text { MIE } \\
\text { Protein } \\
\text { alkylation }\end{array}$ & $\begin{array}{l}\text { Alkylating agents are highly reactive } \\
\text { chemicals that introduce alkyl groups } \\
\text { into biologically active molecules } \\
\text { and thereby prevent their proper } \\
\text { functioning. }\end{array}$ & $\begin{array}{l}\text { Essentiality of the MIE is high. } \\
\text { Covalent protein alkylation by reactive } \\
\text { electrophiles was identified as a key triggering } \\
\text { event in chemical toxicity over } 40 \text { years ago. } \\
\text { These reactions remain a major cause of } \\
\text { chemical-induced toxicity (Codreanu et al., } \\
\text { 2004; Liebler, 2008). }\end{array}$ \\
\hline $\begin{array}{l}\text { KE 1 } \\
\text { cell } \\
\text { injury/death }\end{array}$ & $\begin{array}{l}\text { Covalent binding to liver proteins } \\
\text { and oxidative stress can directly } \\
\text { affect cells or influence signalling } \\
\text { pathways, finally leading to necrotic } \\
\text { or apoptotic cell death. }\end{array}$ & $\begin{array}{l}\text { Essentiality of KE } 1 \text { is high. } \\
\text { Up-regulated apoptosis of hepatocytes is } \\
\text { increasingly viewed as a nexus between liver } \\
\text { injury and fibrosis. Pharmacological inhibition } \\
\text { of liver cell apoptosis attenuates liver injury } \\
\text { and fibrosis, suggesting a critical role for } \\
\text { hepatocyte apoptosis in the initiation of HSC } \\
\text { activation and hepatic fibrogenesis (Canbay et } \\
\text { al., 2004a; Canbay et al., 2003; Canbay et al., } \\
\text { 2002; Faubion and Gores, 1999; Jaeschke, } \\
\text { 2002a; Malhi et al., 2010; Orrenius et al., } \\
\text { 2011; Takehara et al., 2004). }\end{array}$ \\
\hline $\begin{array}{l}\text { KE } 2 \\
\text { Kupffer cell } \\
(\text { KC) } \\
\text { activation } \\
\text { and } \\
\text { macrophage } \\
\text { recruitment }\end{array}$ & $\begin{array}{l}\text { Activated KCs are a major source of } \\
\text { inflammatory mediators, including } \\
\text { cytokines, chemokines, lysosomal } \\
\text { and proteolytic enzymes and a main } \\
\text { source of TGF- } \beta \text {, as well as a major } \\
\text { source of reactive oxygen species } \\
\text { (ROS) }\end{array}$ & $\begin{array}{l}\text { Essentiality of KE } 2 \text { is high. } \\
\text { Probably there is a threshold of KC activation } \\
\text { and release above which liver damage is } \\
\text { induced. Pre-treatment with gadolinium } \\
\text { chloride }(\mathrm{GdCl}) \text {, which inhibits KC function, } \\
\text { reduced both hepatocyte and sinusoidal } \\
\text { epithelial cell injury, as well as decreased the } \\
\text { numbers of macrophages appearing in hepatic } \\
\text { lesions and inhibited TGF- } \beta 1 \text { mRNA } \\
\text { expression in macrophages. Experimental } \\
\text { inhibition of KC function or depletion of KCs } \\
\text { appeared to protect against liver injury from }\end{array}$ \\
\hline
\end{tabular}




\begin{tabular}{|c|c|c|}
\hline & & $\begin{array}{l}\text { the alkylating agent melphalan, the chemical } \\
\text { thioacetamide and the immunostimulants } \\
\text { concanavalin A and Pseudomonas exotoxin } \\
\text { (Andrés et al., 2003; Canbay et al., 2004b; Ide } \\
\text { et al., 2005; Kisseleva and Brenner, 2008; } \\
\text { Kolios et al., 2006; Kresse et al., 2005; } \\
\text { Roberts et al., 2007; Schümann et al., 2000). }\end{array}$ \\
\hline $\begin{array}{l}\text { KE } 3 \\
\text { TGF- } \beta 1 \\
\text { expression }\end{array}$ & $\begin{array}{l}\text { TGF- } \beta 1 \text { is the most potent } \\
\text { profibrogenic cytokine and plays a } \\
\text { central role in fibrogenesis, } \\
\text { mediating a cross-talk between } \\
\text { parenchymal, inflammatory and } \\
\text { collagen expressing cells. }\end{array}$ & $\begin{array}{l}\text { Essentiality of KE } 3 \text { is high. } \\
\text { TGF- } \beta 1 \text { is considered the most potent pro- } \\
\text { fibrogenic cytokine and several reviews assign } \\
\text { this cytokine a central role in fibrogenesis, } \\
\text { especially in HSC activation. Strategies aimed } \\
\text { at disrupting TGF- } \beta 1 \text { expression or signalling } \\
\text { pathways are extensively being investigated } \\
\text { because blocking this cytokine may not only } \\
\text { inhibit matrix production, but also accelerate } \\
\text { its degradation. Animal experiments using } \\
\text { different strategies to block TGF- } \beta 1 \text { have } \\
\text { demonstrated significant anti-fibrotic effect } \\
\text { for liver fibrosis. Experimental fibrosis can be } \\
\text { inhibited by anti-TGF- } \beta \text { treatments with } \\
\text { neutralising antibodies or soluble TbRs (TGF- } \\
\beta \text { receptors) (Cheng et al., 2009; Gressner et } \\
\text { al., } 2002 \text {; Liu et al., } 2006 \text {; Qi et al., 1999; } \\
\text { Tang et al. 2012). } \\
\end{array}$ \\
\hline $\mid \begin{array}{l}\text { KE } 4 \\
\text { hepatic } \\
\text { stellate cell } \\
\text { (HSC) } \\
\text { activation }\end{array}$ & $\begin{array}{l}\text { HSC activation (in response to TGF- } \\
\beta 1 \text { ) means a transdifferentiation from } \\
\text { a quiescent vitamin A-storing cell to } \\
\text { a proliferative and contractile } \\
\text { myofibroblast and is the dominant } \\
\text { event in liver fibrosis. Activated } \\
\text { HSCs (myofibroblasts) are the } \\
\text { primary collagen producing cells, the } \\
\text { key cellular mediators of fibrosis and } \\
\text { a nexus for converging inflammatory } \\
\text { pathways leading to fibrosis. }\end{array}$ & $\begin{array}{l}\text { Essentiality of KE } 4 \text { is high. } \\
\text { Experimental inhibition of HSC activation } \\
\text { prevents fibrosis (Friedman, 2004; Friedman, } \\
\text { 2002; Anan et al., 2006; Kisseleva and } \\
\text { Brenner, 2008; Son et al., 2009; Nakamura et } \\
\text { al., 2014). }\end{array}$ \\
\hline $\begin{array}{l}\text { KE } 5 \\
\text { collagen } \\
\text { accumulation }\end{array}$ & $\begin{array}{l}\text { Excess ECM (extracellular matrix) } \\
\text { deposition and changes in ECM } \\
\text { composition. }\end{array}$ & $\begin{array}{l}\text { Essentiality of KE } 5 \text { is high. } \\
\text { Continuing imbalance between the deposition } \\
\text { and degradation of ECM is a pre-requisite of } \\
\text { liver fibrosis; therefore this KE is essential for } \\
\text { the AO (Lee and Friedman 2011). cite_note- } \\
\text { Lee_and_Friedman_2011-1 }\end{array}$ \\
\hline $\begin{array}{l}\text { Adverse } \\
\text { Outcome } \\
\text { liver fibrosis }\end{array}$ & $\begin{array}{l}\text { Excessive deposition of ECM } \\
\text { proteins occurs as a result of } \\
\text { repeated cycles of hepatocytes injury } \\
\text { and repair and results in liver }\end{array}$ & $\begin{array}{l}\text { It is generally accepted that any chronic form } \\
\text { of liver damage, including any chemical } \\
\text { causing sub-massive hepatocellular injury, can } \\
\text { result in myofibroblast activation, leading to }\end{array}$ \\
\hline
\end{tabular}




\begin{tabular}{|c|c|c|}
\hline & fibrosis. & $\begin{array}{l}\text { hepatic fibrosis and cirrhosis in humans } \\
\text { (Jaeschke et al., 2002b; Lee, 2003: Mehta and } \\
\text { Ozick, 2014; Ramachandran and Kakar, 2009; } \\
\text { Russmann et al., 2009). }\end{array}$ \\
\hline \multicolumn{3}{|c|}{$\begin{array}{l}\text { There are two further events that play an important role in driving fibrogenesis, namely chronic } \\
\text { inflammation and oxidative stress. Both are on-going processes being present throughout the } \\
\text { pathway and interconnected with most of the KEs. Therefore they are not classified as KEs } \\
\text { themselves and described in the individual KE and KER descriptions. Nevertheless a short } \\
\text { overview is given below. }\end{array}$} \\
\hline $\begin{array}{l}\text { Associated } \\
\text { Event } \\
\text { chronic } \\
\text { inflammation }\end{array}$ & $\begin{array}{l}\text { Hepatic fibrosis is commonly } \\
\text { preceded by chronic inflammation } \\
\text { and persistent inflammation has been } \\
\text { associated with progressive hepatic } \\
\text { fibrosis. Hepatic inflammation is a } \\
\text { driver of hepatic fibrosis as the } \\
\text { whole fibrinogenic cascade is } \\
\text { initiated and maintained by } \\
\text { inflammatory mediators and } \\
\text { inflammatory and fibrogenic cells } \\
\text { stimulate each other in amplifying } \\
\text { fibrosis. Damaged hepatocytes } \\
\text { release inflammatory cytokines that } \\
\text { activate KCs and stimulate the } \\
\text { recruitment of inflammatory cells, } \\
\text { which produce profibrotic cytokines } \\
\text { and chemokines that further activate } \\
\text { fibroblastic cells. Activated HSCs } \\
\text { secrete various cytokines (like } \\
\text { macrophage colony-stimulating } \\
\text { factor (M-CSF), MCP-1 and IL-6) } \\
\text { and inflammatory chemokines, they } \\
\text { interact directly with immune cells } \\
\text { through expression of adhesion } \\
\text { molecules (mediated by TNF- } \alpha \text { and } \\
\text { facilitating the recruitment of } \\
\text { inflammatory cells), and they } \\
\text { modulate the immune system } \\
\text { through antigen presentation. } \\
\text { Signalling of HSCs in response to } \\
\text { either lipopolysaccharides (LPS) or } \\
\text { endogenous TLR4 ligands down- } \\
\text { regulates the protein activin } \\
\text { membrane-bound inhibitor } \\
\text { (BAMBI), a transmembrane } \\
\text { suppressor of TGF- } \beta 1 . \text { Other } \\
\text { inflammatory cells regulating }\end{array}$ & $\begin{array}{l}\text { Essentiality of inflammation is high. } \\
\text { Suppression of inflammatory activity by } \\
\text { eliminating the etiological agent (e.g. a virus) } \\
\text { or dampening the immune response } \\
\text { (lymphocytic proliferation and infiltration) } \\
\text { can halt and even reverse the fibrotic process } \\
\text { (Bataller and Brenner, 2005; Czaja, 2014; } \\
\text { Guo and Friedman, 2010; Henderson and } \\
\text { Iredale, 2007; Kershenobich Stalnikowitz and } \\
\text { Weissbrod, 2003; Lee and Friedman, 2011; } \\
\text { Marra, 2002; Parola and Robino, 2001; } \\
\text { Sivakumar and Das, 2008). }\end{array}$ \\
\hline
\end{tabular}




\begin{tabular}{|c|c|c|}
\hline & $\begin{array}{l}\text { progression and resolution of fibrosis } \\
\text { include T-cells, dendritic cells, liver } \\
\text { sinusoidal endothelial cells (LSECs) } \\
\text { and natural killer cells (NKs), which } \\
\text { exert an anti-fibrotic activity by } \\
\text { inducing HSC apoptosis through } \\
\text { production of IFN } \gamma \text {. Chronic } \\
\text { inflammatory response is often } \\
\text { accompanied simultaneously by } \\
\text { tissue destruction and repair. } \\
\text { Activated inflammatory cells } \\
\text { represent a major source of oxidative } \\
\text { stress-related molecules. }\end{array}$ & \\
\hline $\begin{array}{l}\text { Associated } \\
\text { Event } \\
\text { oxidative } \\
\text { stress }\end{array}$ & $\begin{array}{l}\text { Oxidative stress corresponds to an } \\
\text { imbalance between the rate of } \\
\text { oxidant production and that of } \\
\text { degradation and plays a crucial role } \\
\text { in liver fibrogenesis by inducing } \\
\text { hepatocyte apoptosis and activation } \\
\text { of KCs and HSCs. Oxidative stress- } \\
\text { related molecules act as mediators to } \\
\text { modulate tissue and cellular events } \\
\text { responsible for the progression of } \\
\text { liver fibrosis. ROS, including } \\
\text { superoxide, hydrogen peroxide, } \\
\text { hydroxyl radicals and aldehydic end } \\
\text { products, may be derived from } \\
\text { hepatocytes (generated through } \\
\text { cytochrome P450, lipid } \\
\text { peroxidation), as well as from } \\
\text { activated KCs, other inflammatory } \\
\text { cells and HSCs (by NOX). Excessive } \\
\text { levels of ROS can lead to } \\
\text { hepatocellular injury and death. } \\
\text { Under conditions of oxidative stress } \\
\text { macrophages are activated, which } \\
\text { leads to a more enhanced } \\
\text { inflammatory response. Oxidative } \\
\text { stress can activate a variety of } \\
\text { transcription factors like NF- } \mathrm{B} \text {, } \\
\text { PPAR- } \gamma \text { which may further lead to } \\
\text { increased gene expression for the }\end{array}$ & $\begin{array}{l}\text { Essentiality of oxidative stress is moderate. } \\
\text { Oxidative stress-related molecules act as } \\
\text { mediators to modulate tissue and cellular } \\
\text { events responsible for the progression of liver } \\
\text { fibrosis. Hence ROS likely contribute to both } \\
\text { onset and progression of fibrosis, being } \\
\text { simultaneously cause and consequence of the } \\
\text { observed condition (El-Rigal et al., } \\
\text { 2013; Kirkham, 2007; Kisseleva and Brenner, } \\
\text { 2007; Paik et al., 2011; Parola and Robino, } \\
\text { 2001; Parsons et al., 2007; Poli, 2000; } \\
\text { Sánchez-Valle et al., 2012). }\end{array}$ \\
\hline
\end{tabular}




\begin{tabular}{|c|c|c|}
\hline & $\begin{array}{l}\text { production of growth factors, } \\
\text { inflammatory cytokines and } \\
\text { chemokines. }\end{array}$ & \\
\hline \multicolumn{3}{|c|}{ Support for biological plausibility of KERs } \\
\hline $\mathrm{MIE}=>\mathrm{KE} 1$ & $\begin{array}{l}\text { Hepatocytes are damaged by } \\
\text { alkylating agents via both covalent } \\
\text { binding to liver proteins and lipid } \\
\text { peroxidation accompanied by } \\
\text { oxidative stress and collapse of } \\
\text { mitochondrial membrane potential, } \\
\text { which triggers apoptotic cell death. }\end{array}$ & $\begin{array}{l}\text { Biological plausibility of the MIE => KE1 is } \\
\text { high. } \\
\text { There is a mechanistic relationship between } \\
\text { MIE and KE } 1 \text { consistent with established } \\
\text { biological knowledge (Codreanu et al., 2014; } \\
\text { Kehrer and Biswal, 2000; Liebler, 2008; } \\
\text { Manibusan et al., 2007; Tanel et al. 2007). }\end{array}$ \\
\hline KE $1 \Rightarrow$ KE 2 & $\begin{array}{l}\text { Damaged hepatocytes release ROS, } \\
\text { cytokines and chemokines which } \\
\text { lead to oxidative stress, } \\
\text { inflammatory signalling and } \\
\text { activation of KCs. Apoptotic } \\
\text { hepatocytes undergo genomic DNA } \\
\text { fragmentation and formation of } \\
\text { apoptotic bodies. Upon engulfment } \\
\text { of apoptotic bodies KCs are } \\
\text { activated. Liver cells trigger a } \\
\text { sterile inflammatory response with } \\
\text { activation of innate immune cells } \\
\text { through release of damage- } \\
\text { associated molecular patterns } \\
\text { (DAMPs). Through toll-like } \\
\text { receptors KCs are additionally } \\
\text { activated. }\end{array}$ & $\begin{array}{l}\text { Biological plausibility of KE1 => KE2 is } \\
\text { high. } \\
\text { There is a functional relationship between KE } \\
1 \text { and KE } 2 \text { consistent with established } \\
\text { biological knowledge (Canbay et al., 2004a; } \\
\text { Jaeschke, 2011; Kisseleva and Brenner, 2008; } \\
\text { Kolios et al., 2006; Li et al., 2008; Luckey and } \\
\text { Petersen, 2001; Malhi et al., 2010; Orrenius et } \\
\text { al., 2011; Poli, 2000; Roberts et al., 2007; } \\
\text { Winwood and Arthur, 1993). }\end{array}$ \\
\hline KE $1 \Rightarrow$ KE 4 & $\begin{array}{l}\text { Like KCs, also HSCs are activated } \\
\text { by damaged hepatocytes through } \\
\text { the release of ROS, cytokines and } \\
\text { chemokines and upon engulfment } \\
\text { of apoptotic bodies from } \\
\text { hepatocytes. DNA from apoptotic } \\
\text { hepatocytes induces toll-like } \\
\text { receptor } 9 \text { (TLR9)-dependent } \\
\text { changes of HSCs that are consistent } \\
\text { with late stages of HSC } \\
\text { differentiation (activation), with } \\
\text { up-regulation of collagen } \\
\text { production and inhibition of } \\
\text { platelet derived growth factor } \\
\text { (PDGF)-mediated chemotaxis to } \\
\text { retain HSCs at sites of cellular } \\
\text { apoptosis. The release of latent } \\
\text { TGF- } \beta \text { complex into the micro- }\end{array}$ & $\begin{array}{l}\text { Biological plausibility of KE1 => KE4 is } \\
\text { high. } \\
\text { HSCs activation by hepatocytes is only a } \\
\text { contributing factor and not the main route; } \\
\text { partly it is mediated by TGF- } \beta 1 \text {; therefore this } \\
\text { relationship is classified as indirect. } \\
\text { Nevertheless, there is a functional relationship } \\
\text { between KE } 1 \text { and KE } 4 \text { consistent with } \\
\text { established biological knowledge (Canbay et } \\
\text { al., 2004a; Friedman, 2008; Gressner et al., } \\
\text { 2002; Kisseleva and Brenner, 2008; Kolios et } \\
\text { al., 2006; Lee and Friedman, 2011; Li et al., } \\
\text { 2008; Malhi et al., 2010; Orrenius et al., 2011; } \\
\text { Roth et al., 1998). }\end{array}$ \\
\hline
\end{tabular}




\begin{tabular}{|c|c|c|}
\hline & $\begin{array}{l}\text { environment by damaged } \\
\text { hepatocytes is likely to be one of } \\
\text { the first signals for adjacent HSCs } \\
\text { leading to their activation. }\end{array}$ & \\
\hline $\mathrm{KE} 2 \Rightarrow \mathrm{KE} 3$ & $\begin{array}{l}\text { Following activation KCs become a } \\
\text { main source of TGF- } \beta 1 \text {, the most } \\
\text { potent profibrogenic cytokine, as } \\
\text { well as a major source of } \\
\text { inflammatory } \\
\text { mediators,chemokines, and ROS. }\end{array}$ & $\begin{array}{l}\text { Biological plausibility of KE2 }=>\text { KE3 is } \\
\text { high. } \\
\text { The functional relationship between KE } 2 \text { and } \\
\text { KE } 3 \text { is consistent with biological knowledge } \\
\text { (Bataller and Brenner, 2005; Brenner, 2009; } \\
\text { Fujiwara and Kobayashi, 2005; Guo, and } \\
\text { Friedman, 2007; Kamimura and Tsukamoto, } \\
\text { 1995; Kirkham, 2007; Kolios et al., 2006; Lee } \\
\text { and Frieedmann, 2011; Li et al., 2008; Reuter } \\
\text { et al., 2010). }\end{array}$ \\
\hline KE $3 \Rightarrow$ KE 4 & $\begin{array}{l}\text { TGF- } \beta 1 \text { activates HSCs, i.e. } \\
\text { stimulates cell proliferation, matrix } \\
\text { synthesis, and release of retinoids } \\
\text { by HSCs and is the most potent } \\
\text { fibrogenic factor for HSCs. }\end{array}$ & $\begin{array}{l}\text { Biological plausibility of KE3 => KE4 is } \\
\text { high. } \\
\text { There is good understanding and broad } \\
\text { acceptance of the KER between KE } 3 \text { and KE } \\
4 \text { (Bataller and Brenner, 2005; Brenner, 2009; } \\
\text { Friedman, 2008; Gressner et al., 2002; Guo } \\
\text { and Friedman, 2007; Kaimori et al., 2007; } \\
\text { Kershenobich Stalnikowitz and Weissbrod, } \\
\text { 2003; Kisseleva and Brenner, 2008; Kisseleva } \\
\text { and Brenner, 2007; Kolios et al., 2006; Li et } \\
\text { al., 2008; Liu et al., 2006; Matsuoka and } \\
\text { Tsukamoto, 1990; Parsons et al., 2007; Poli, } \\
\text { 2000; Qi et al., 1999; Williams et al., 2000). }\end{array}$ \\
\hline $\mathrm{KE} 4 \Rightarrow \mathrm{KE} 5$ & $\begin{array}{l}\text { In response to TGF- } \beta 1 \text { activated } \\
\text { HSCs up-regulate collagen } \\
\text { synthesis. Together with decreased } \\
\text { matrix degradation ECM } \\
\text { composition changes and further } \\
\text { stimulates HSC activation and } \\
\text { production of TGF- } \beta 1, \text { which } \\
\text { further promotes activation of } \\
\text { neighbouring quiescent HSCs. }\end{array}$ & $\begin{array}{l}\text { Biological plausibility of KE4 => KE5 is } \\
\text { high. } \\
\text { The functional relationship between KE } 4 \text { and } \\
\text { KE } 5 \text { is consistent with biological knowledge } \\
\text { and generally accepted (Bataller and Brenner, } \\
\text { 2005; Benyon and Arthur, 2001; Brenner, } \\
\text { 2009; Guo and Friedman, 2007; Kershenobich } \\
\text { Stalnikowitz and Weissbrod, 2003; Kolios et } \\
\text { al., 2006; Lee and Friedman, 2011; Li et al., } \\
\text { 2008; López-Novoa and Nieto, 2009; Milani } \\
\text { et al., 1994; Safadi and Friedman, 2002). }\end{array}$ \\
\hline $\mathrm{KE} 5 \Rightarrow \mathrm{AO}$ & $\begin{array}{l}\text { Excessive accumulation of ECM } \\
\text { proteins leads to disruption of } \\
\text { normal hepatic architecture. }\end{array}$ & $\begin{array}{l}\text { Biological plausibility of KE5 => AO is high. } \\
\text { By definition, liver fibrosis is the excessive } \\
\text { accumulation of ECM proteins that are } \\
\text { produced by HSCs. The KER between KE } 5 \\
\text { and the AO is undisputed (Bataller and } \\
\text { Brenner, 2005; Brancatelli et al., 2009; Lee } \\
\text { and Friedman, 2011; Poynard et al., 1997; } \\
\text { Rockey et al., 2006). }\end{array}$ \\
\hline
\end{tabular}




\begin{tabular}{|c|c|c|}
\hline \multicolumn{3}{|c|}{ Empirical support for KERs } \\
\hline \multicolumn{3}{|c|}{$\begin{array}{l}\text { There is a need for more advanced in vitro models systems for chemical-induced hepatotoxicity to } \\
\text { study intercellular signalling and dose-response data on KERs. Nevertheless, some empirical } \\
\text { evidence exists to support that a change in } \mathrm{KE}_{\text {up }} \text { leads to an appropriate change in the respective } \\
\mathrm{KE}_{\text {down. }}\end{array}$} \\
\hline $\mathrm{MIE}=>\mathrm{KE} 1$ & \begin{tabular}{|l|} 
It is general accepted knowledge that \\
alkylating chemicals damage cells. \\
Although covalent protein alkylation \\
is a feature of many hepatotoxic drugs \\
the overall extent of binding does not \\
adequately distinguish toxic from non- \\
toxic binding. It is not known whether \\
protein alkylation to certain proteins is \\
required and whether particular \\
proteins and various binding sites \\
influence the further downstream \\
process. Further, we do not know \\
whether there is a threshold and if this \\
threshold would refer to the number of \\
alkylation of a single protein or of a \\
threshold number of proteins.
\end{tabular} & $\begin{array}{l}\text { Empirical support of the MIE => KE } 1 \text { is } \\
\text { moderate. } \\
\text { There is exposure-dependent change in } \\
\text { both events following exposure with } \\
\text { temporal concordance (Bauman et al., } \\
\text { 2009; Bauman et al., 2008; Codreanu et al., } \\
\text { 2014; Schwend et al., 2008; Thompson and } \\
\text { Burcham, 2008). }\end{array}$ \\
\hline $\mathrm{KE} 1 \Rightarrow \mathrm{KE} 2$ & \begin{tabular}{|l|} 
Specific markers for activated KCs \\
have not been identified yet. KC \\
activation cannot be detected by \\
staining techniques since cell \\
morphology does not change, but \\
cytokines release can be measured \\
(with the caveat that KCs activate \\
spontaneously in vitro). Tukov et al. \\
(2006) examined the effects of KCs \\
cultured in contact with rat \\
hepatocytes. They found that by \\
adding KCs to the cultures they could \\
mimic in vivo drug-induced \\
inflammatory responses. Canbay et al. \\
(2003) could prove that engulfment of \\
hepatocyte apoptotic bodies stimulated \\
cytokine expression by KCs.
\end{tabular} & $\begin{array}{l}\text { Empirical support of the KE } 1=>\mathrm{KE} 2 \text { is } \\
\text { moderate. } \\
\text { There are limited experimental studies } \\
\text { which could show that there is a direct } \\
\text { relationship between these two events with } \\
\text { temporal concordance (Canbay et al., 2003; } \\
\text { LeCluyse et al., 2012; Soldatow et al., } \\
\text { 2013; Tukov et al., 2006). }\end{array}$ \\
\hline $\mathrm{KE} 1 \Rightarrow \mathrm{KE} 4$ & $\begin{array}{l}\text { Canbay et al. (2002; 2004b) could } \\
\text { show that Fas-mediated hepatocyte } \\
\text { injury is mechanistically linked to } \\
\text { liver fibrogenesis. Markers of HSC } \\
\text { activation were significantly reduced } \\
\text { when apoptosis was prevented in Fas- } \\
\text { deficient bile duct ligated mice. These } \\
\text { findings (reduction of inflammation, }\end{array}$ & $\begin{array}{l}\text { Empirical support of the KE } 1=>\mathrm{KE} 4 \text { is } \\
\text { moderate. } \\
\text { There is experimental evidence for this } \\
\text { KER (Canbay et al., 2004b; Canbay et al., } \\
\text { 2002; Coulouarn et al., 2012; Watanabe et } \\
\text { al., 2007). }\end{array}$ \\
\hline
\end{tabular}




\begin{tabular}{|c|c|c|}
\hline & \begin{tabular}{|l|} 
markers of HSC activation, and \\
collagen I expression) could be \\
repeated by pharmacological \\
inhibition of liver cell apoptosis using \\
a pan-caspase inhibitor. Watanabe et \\
al. (2007) could demonstrate in vitro \\
that DNA from apoptotic hepatocytes \\
acts as an important mediator of HSC \\
differentiation by providing a stop \\
signal to mobile HSCs when they have \\
reached an area of apoptosing \\
hepatocytes and inducing a stationary \\
phenotype-associated up-regulation of \\
collagen production. Coulouarn et al. \\
(2012) found in a co-culture model \\
that hepatocyte - HSC crosstalk \\
engenders a permissive inflammatory \\
micro-environment.
\end{tabular} & \\
\hline $\mathrm{KE} 2 \Rightarrow \mathrm{KE} 3$ & $\begin{array}{l}\text { Experiments by Matsuoka and } \\
\text { Tsukamoto (1990) showed that KCs } \\
\text { isolated from rat liver with alcoholic } \\
\text { fibrosis express and release TGF- } \beta 1 \\
\text { and that this cytokine is largely } \\
\text { responsible for the KC-conditioned } \\
\text { medium-induced stimulation of } \\
\text { collagen formation by HSCs. } \\
\text { Accumulated CD11b1 macrophages } \\
\text { are critical for activating HSCs (via } \\
\text { expression of TGF- } \beta 1 \text { ) (Chu et al., } \\
\text { 2013). }\end{array}$ & $\begin{array}{l}\text { Empirical support of the KE } 2=>\text { KE } 3 \text { is } \\
\text { moderate. } \\
\text { Cytokine release is one of the features that } \\
\text { define KC activation and there is sound } \\
\text { empirical evidence for this KER (Chu et } \\
\text { al., 2013; Matsuoka and Tsukamoto). }\end{array}$ \\
\hline $\mathrm{KE} 3 \Rightarrow \mathrm{KE} 4$ & $\begin{array}{l}\text { Czaja et al. (1989) could prove that } \\
\text { treatment of cultured hepatic cells } \\
\text { with TGF- } \beta 1 \text { increased type I pro- } \\
\text { collagen mRNA levels } 13 \text {-fold due to } \\
\text { post-transcriptional gene regulation. } \\
\text { Tan et al. (2013) discovered that short } \\
\text { TGF- } \beta 1 \text { pulses can exert long-lasting } \\
\text { effects on fibroblasts. Difficulties are } \\
\text { that HSCs cultured on plastic, undergo } \\
\text { spontaneous activation and HSCs } \\
\text { activated in culture do not fully } \\
\text { reproduce the changes in gene } \\
\text { expression observed in vivo. De } \\
\text { Minicis et al. (2007) investigated gene } \\
\text { expression changes in } 3 \text { different } \\
\text { models of HSC activation and }\end{array}$ & $\begin{array}{l}\text { Empirical support of the KE } 3=>\mathrm{KE} 4 \text { is } \\
\text { moderate. } \\
\text { Qualitative empirical evidence with } \\
\text { temporal and incidence concordance for } \\
\text { this KER exists (Czaja et al., 1989; De } \\
\text { Minicis et al., 2007; Tan et al., 2013; Yin et } \\
\text { al., 2013). }\end{array}$ \\
\hline
\end{tabular}




\begin{tabular}{|c|c|c|}
\hline & $\begin{array}{l}\text { compared gene expression profiles in } \\
\text { culture (mice HSCs in co-culture with } \\
\text { KCs) and in vivo and did not find a } \\
\text { proper correlation. }\end{array}$ & \\
\hline KE $4 \Rightarrow$ KE 5 & $\begin{array}{l}\text { It is difficult to stimulate sufficient } \\
\text { production of collagen and its } \\
\text { subsequent incorporation into a } \\
\text { pericellular matrix in vitro; therefore } \\
\text { analytical methods have focused on } \\
\text { measurement of pro-collagen secreted } \\
\text { into culture medium or measurement } \\
\text { of } \alpha \text {-smooth muscle actin ( } \alpha \text {-SMA) } \\
\text { expression, a marker of fibroblast } \\
\text { activation. In primary culture, HSCs } \\
\text { from normal liver began to express } \alpha- \\
\text { SMA coincident with culture-induced } \\
\text { activation. }\end{array}$ & $\begin{array}{l}\text { Empirical support of the KE } 4=>\text { KE } 5 \text { is } \\
\text { moderate. } \\
\text { It is general accepted knowledge that } \\
\text { activated HSCs (=myofibroblasts) are } \\
\text { collagen-producing cells (Chen and } \\
\text { Raghunath, 2009; Rockey et al., 1992). }\end{array}$ \\
\hline KE $5 \Rightarrow$ AO & $\begin{array}{l}\text { Liver fibrosis results from chronic } \\
\text { damage in conjunction with the } \\
\text { accumulation of ECM proteins, which } \\
\text { distorts the hepatic architecture by } \\
\text { forming a fibrous scar. The onset of } \\
\text { liver fibrosis is usually insidious and } \\
\text { progression to cirrhosis occurs after an } \\
\text { interval of } 15-20 \text { years. }\end{array}$ & $\begin{array}{l}\text { Empirical support of the KE } 5=>\mathrm{AO} \text { is } \\
\text { high. } \\
\text { There is a smooth transition from ECM } \\
\text { accumulation to liver fibrosis without a } \\
\text { definite threshold and plenty in vivo } \\
\text { evidence exists that ECM accumulation is a } \\
\text { pre-stage of liver fibrosis (Bataller and } \\
\text { Brenner, 2005). }\end{array}$ \\
\hline
\end{tabular}

Essentiality of the Key Events

\begin{tabular}{|l|l|}
\hline Molecular Initiating Event & Support for essentiality \\
\hline Protein, alkylation & Strong \\
\hline
\end{tabular}

\begin{tabular}{|l|l|}
\hline \multicolumn{1}{|c|}{ Key Event } & Support for essentiality \\
\hline Cell death, N/A & Strong \\
\hline Hepatic macrophages (Kupffer Cells), activation & Strong \\
\hline TGFbeta1 expression, up regulation & Strong \\
\hline Stellate cells, activation & Strong \\
\hline Collagen, accumulation & Strong \\
\hline
\end{tabular}

The essentiality of each of the KEs for this AOP was rated high as there is much experimental evidence that the blocking of one KE prevents (or attenuates where complete blocking is not possible) the next downstream KE and therefore the whole AOP. Much evidence arises from 
preclinical research for antifibrotic agents, which is mainly based on the interference with or blockade of a key event. For details see the table above

Quantitative Considerations

\begin{tabular}{|l|l|l|l|}
\hline \multicolumn{1}{|c|}{ Event } & Description & \multicolumn{1}{|c|}{ Triggers } & \multicolumn{1}{c|}{$\begin{array}{c}\text { Quantitative } \\
\text { understanding }\end{array}$} \\
\hline Protein, alkylation & $\begin{array}{l}\text { Directly leads } \\
\text { to }\end{array}$ & Cell death, N/A & \\
\hline Cell death, N/A & $\begin{array}{l}\text { Directly leads } \\
\text { to }\end{array}$ & $\begin{array}{l}\text { Hepatic macrophages (Kupffer } \\
\text { Cells), activation }\end{array}$ & \\
\hline Cell death, N/A & $\begin{array}{l}\text { Indirectly } \\
\text { leads to }\end{array}$ & Stellate cells, activation & \\
\hline $\begin{array}{l}\text { Hepatic macrophages (Kupffer } \\
\text { Cells), activation }\end{array}$ & $\begin{array}{l}\text { Directly leads } \\
\text { to }\end{array}$ & $\begin{array}{l}\text { TGFbeta1 expression, } \\
\text { regulation }\end{array}$ \\
\hline $\begin{array}{l}\text { TGFbeta1 expression, up } \\
\text { regulation }\end{array}$ & $\begin{array}{l}\text { Directly leads } \\
\text { to }\end{array}$ & Stellate cells, activation \\
\hline Stellate cells, activation & $\begin{array}{l}\text { Directly leads } \\
\text { to }\end{array}$ & Collagen, accumulation \\
\hline Collagen, accumulation & $\begin{array}{l}\text { Directly leads } \\
\text { to }\end{array}$ & Liver fibrosis, N/A & \\
\hline
\end{tabular}

More advanced in vitro models systems are needed to study chemical-induced hepatotoxicity. Modulations of hepatotoxicity by intercellular signalling cannot be addressed in primary cultures of hepatocytes alone but require co-cultures of different liver cell types. Various co-cultures systems with two or more different liver cell types are currently being developed, but quantitative data on KERs are not available yet.

Applicability of the AOP

Life stage applicability

\begin{tabular}{|c|c|}
\hline Life stage & Evidence \\
\hline Not otherwise specified & \\
\hline
\end{tabular}

Taxonomic applicability

\begin{tabular}{|l|l|l|l|}
\hline Name & Scientific name & Evidence & Links \\
\hline human & Homo sapiens & Strong & NCBI \\
\hline
\end{tabular}




\begin{tabular}{|l|l|l|l|}
\hline Name & Scientific name & Evidence & Links \\
\hline rat & Rattus norvegicus & Strong & NCBI \\
\hline
\end{tabular}

Sex applicability

\begin{tabular}{|c|c|}
\hline Sex & Evidence \\
\hline Unspecific & \\
\hline
\end{tabular}

The described AOP is valid for both sexes and any life stage. This pathway description is also based on studies of formation and progression of fibrosis in human patients. Findings suggest common conserved pathways across different species which initiate and promote liver fibrosis. Animal models are used to study fibrogenesis and $\mathrm{CCl}_{4}$ intoxication in rats and mice is probably the most widely studied and therefore best characterised model with respect to histological, biochemical, cell, and molecular changes associated with the development of fibrosis (Constandinou et al., 2005; Crespo Yanguas S et al., 2015; Iredale, 2007; Tsukamoto et al., 1990; Weber et al., 2010).

Is the AOP specific to certain tissues, life stages / age classes?

The complex mechanism of fibrogenesis does not only affect a single organ, but causes a systemic response which equally damages other organs and tissues. The described findings in liver fibrosis parallel those in studies of fibrogenesis in other organs; everywhere are the same kind of cells and soluble factors involved (Friedman, 2010; Friedman, 2002; Weber et al., 2010). For example, the reference compound $\mathrm{CCl}_{4}$ equally affects lymphoid organs, lungs and kidneys (Kisseleva and Brenner, 2008). Fibrosis may affect lung, kidney, heart and blood vessels, eye, skin, pancreas, intestine, brain and bone marrow. Multi-organ fibrosis occurs due to mechanical injury or can be drug- or radiation-induced (Constandinou et al., 2005; Iredale, 2007; Sivakumar and Das, 2008; Tsukamoto et al., 1990).

As many fibrogenic pathways are conserved across tissues, recent findings in the liver could be extended to studies of fibrosis in the lungs, the kidneys, the heart and other organs.

\section{Considerations for potential applications of the AOP}

This systematic and coherent display of currently available mechanistic-toxicological information can serve as a knowledge-based repository for identification/selection/development of in vitro methods suitable for measuring KEs and their relationships along the AOP and to facilitate the use of alternative data for regulatory purposes. Identified uncertainties and knowledge gaps can direct future research by priority setting and targeted testing. The KE descriptions can be used for hazard identification and read-across to assess the toxic potential of an untested substance. A sufficiently detailed description of the AOP to liver fibrosis might support chemical risk assessment by indicating early (upstream) markers for downstream events and facilitate a testing strategy without the need for an elaborated cell model. 


\section{References}

Akhtar, T. and N. Sheikh (2013), An overview of thioacetamide-induced hepatotoxicity, Toxin Reviews, vol. 32, no. 3, pp. 43-46.

Al-Ali, S.Y., I.M. Hassan and S. Sadek (2005), Ultrastructural changes in rat livers perfused in vitro and in vivo with a high dose of methotrexate, Histol Histopathol, vol. 20, no. 4, pp. 1131-1145.

Al-Motabagani, M.A. (2006), Histological and histochemical studies on the effects of methotrexate on the liver of adult male albino rat, Int. J. Morphol, vol. 24, no. 3, pp. 417422.

Altomonte, J. et al. (2013), Antifibrotic properties of transarterial oncolytic VSV therapy for hepatocellular carcinoma in rats with thioacetamide-induced liver fibrosis, Mol Ther, vol. 21, no. 11, pp. 2032-2042.

Amin, Z.A. et al. (2013), Gene expression profiling reveals underlying molecular mechanism of hepatoprotective effect of Phyllanthus niruri on thioacetamide-induced hepatotoxicity in Sprague Dawley rats, BMC Complement Altern Med, vol. 5, no. 13, p. 160.

Anan, A. et al. (2006), Proteasome inhibition induces hepatic stellate cell apoptosis, Hepatology, vol. 43, no. 2, pp. 335-344.

Andrés, D. et al. (2003), Depletion of Kupffer cell function by gadolinium chloride attenuates thioacetamide-induced hepatotoxicity. Expression of metallothionein and HSP70, Biochem. Pharmacol, vol. 66, no. 6, pp. 917-926.

Antherieu, S. et al, (2013), Oxidative stress plays a major role in chlorpromazine-induced cholestasis in human HepaRG cells, Hepatology, vol. 57, no. 4, pp. 1518-29.

Auerbach, S. et al. (2008), A comparative 90 day toxicity study of allyl acetate, allyl alcohol and acrolein, Toxicology; vol. 253, no. 1-3, pp. 79-88.

Basu, S. (2003), Carbon tetrachloride-induced lipid peroxidation: eicosanoid formation and their regulation by antioxidant nutrients, Toxicology, vol. 189, no. 1-2, pp. 113-127.

Bataller, R. and D.A. Brenner (2005), Liver Fibrosis, J.Clin. Invest, vol. 115, no. 2, pp. 209-218.

Bataller, R. et al. (2003), NADPH oxidase signal transduces angiotensin II in hepatic stellate cells and is critical in hepatic fibrosis, J Clin Invest, vol. 112, no.9, pp. 1383-1394.

Bauman, J.N. et al. (2009), Can in vitro metabolism-dependent covalent binding data distinguish hepatotoxic from nonhepatotoxic drugs? An analysis using human hepatocytes and liver S-9 fraction, Chem Res Toxicol, vol. 22, no. 2, pp. 332-340.

Bauman, J.N. et al. (2008), Comparison of the bioactivation potential of the antidepressant and hepatotoxin nefazodone with aripiprazole, a structural analog and marketed drug, Drug Metab Dispos, vol. 36, no. 6, pp. 1016-1029.

Belinsky, G.S. et al. (2007), The contribution of methotrexate exposure and host factors on transcriptional variance in human liver, Toxicological Sciences, vol. 97, no. 2, pp. 582-594.

Benyon, R.C. and M.J. Arthur (2001), Extracellular matrix degradation and the role of stellate cells, Semin Liver Dis, vol. 21, no. 3, pp. 373-384.

Bhadauria, S. et al. (2007), Isoniazid induces oxidative stress, mitochondrial dysfunction and apoptosis in Hep G2 cells, Cell Mol Biol (Noisy-le-grand), vol. 53, no. 1, pp. 102-114. 
Brancatelli, G. et al. (2009), Focal confluent fibrosis in cirrhotic liver: natural history studied with serial CT, AJR Am J Roentgenol, vol. 192, no. 5, pp. 1341-1347.

Brattin, W. et al. (1985), Pathological mechanisms in carbon tetrachloride hepatotoxicity, J Free Radic Biol Med, vol. 1, no. 1, pp. 27-38.

Brenner, D.A. (2009), Molecular Pathogenesis of Liver Fibrosis, Trans Am Clin Climatol Assoc, vol. 120, pp. 361-368.

Calabrese, E.J. and H.M. Mehendale (1996), A review of the role of tissue repair as an adaptive strategy: why low doses are often non-toxic and why high doses can be fatal, Food Chem Toxicol, vol. 34, no. 3, pp. 301-311.

Calabrese, E.J., L.A. Baldwin and H.M. Mehendale (1993), G2 subpopulation in rat liver induced into mitosis by low-level exposure to carbon tetrachloride: an adaptive response, Toxicol Appl Pharmacol, vol. 121. no. 1, pp. 1-7.

Canbay, A., S.L. Friedman and G.J. Gores (2004a), Apoptosis: the nexus of liver injury and fibrosis, Hepatology, vol. 39, no. 2, pp. 273-278.

Canbay, A. et al. (2004b), The caspase inhibitor IDN-6556 attenuates hepatic injury and fibrosis in the bile duct ligated mouse, J Pharmacol Exp Ther, vol. 308, no. 3, pp. 1191-1196.

Canbay, A. et al. (2003a), Cathepsin B inactivation attenuates hepatic injury and fibrosis during cholestasis, J Clin Invest, vol. 112, no. 2, pp. 152-159.

Canbay, A. et al. (2002), Fas enhances fibrogenesis in the bile duct ligated mouse: a link between apoptosis and fibrosis, Gastroenterology, vol. 123, no. 4, pp. 1323-1330.

Castano, G. et al. (2006), Vitamin A toxicity in a physical culturist patient: a case report and review of literature, Annals of Hepatology, vol 5, no. 4, pp. 293-295.

Chatziantoniou, Ch. and J.C. Dussaule (2005), Insights into the mechanisms of renal fibrosis: is it possible to achieve regression, Am J Physiol Renal Physiol, vol. 289, no. 2, pp. F227-F234.

Chen, C. and M. Raghunath (2009), Focus on collagen: in vitro systems to study fibrogenesis and antifibrosis state of the art, Fibrogenesis Tissue Repair, vol. 15, no. 2, p. 7.

Cheng, K., N.Yang and R.I. Mahato (2009), TGF-beta1 gene silencing for treating liver fibrosis, Mol Pharm, vol. 6, no. 3, pp. 772-779.

Chilakapati, J. et al. (2005), Saturation toxicokinetics of thioacetamide: role in initiation of liver injury, Drug Metab Dispos, vol. 33, no.12, pp. 1877-1885.

Chu, P.S. et al. (2013), C-C motif chemokine receptor 9 positive macrophages activate hepatic stellate cells and promote liver fibrosis in mice, Hepatology, vol. 58, no. 1, pp. 337-350.

Cimic, A. and J. Sirintrapun (2013), Amiodarone hepatotoxicity with absent phospholipidosis and steatosis: a case report and review of amiodarone toxicity in various organs, Case Reports in Pathology, Article ID 201095. doi:10.1155/2013/201095.

Clawson, G.A. (1989), Mechanisms of carbon tetrachloride hepatotoxicity, Pathol Immunopathol Res, vol. 8, no. 2, pp. 104-112.

Codreanu, S.G. et al. (2014), Alkylation damage by lipid electrophiles targets functional protein systems, Molecular \& Cellular Proteomics, vol. 13, no. 3, pp.849-859.

Constandinou, C., N.C. Henderson and J.P. Iredale (2005), Modelling liver fibrosis in rodents, Methods Mol Med, vol. 117, pp. 237-250. 
Coulouarn, C. et al. (2012), Hepatocyte-stellate cell cross-talk in the liver engenders a permissive inflammatory microenvironment that drives progression in hepatocellular carcinoma, Cancer Res, vol. 72, no. 10, pp. 2533-2542.

Crespo Yanguas, S. et al. (2015), Experimental models of liver fibrosis, Arch Toxicol. [Epub ahead of print] DOI 10.1007/s00204-015-1543-4

Czaja, A.J. (2014), Hepatic inflammation and progressive liver fibrosis in chronic liver disease, World J Gastroenterol, vol. 20, no. 10, 2515-2532.

Czaja, M.J. et al. (1989), In vitro and in vivo association of transforming growth factor-beta 1 with hepatic fibrosis, J Cell Biol, vol. 108, no. 6, pp. 2477-2482.

Dalton, S.R. et al. (2009), Carbon tetrachloride-induced liver damage in asialoglycoprotein receptor-deficient mice, Biochem Pharmacol, vol. 77, no. 7, pp. 1283-1290.

Dalu, A. and H.M. Mehendale (1996), Efficient tissue repair underlies the resiliency of postnatally developing rats to chlordecone + CCl4 hepatotoxicity, Toxicology, vol. 111, no. 1-3, pp. 2942.

Das, S.K. et al. (2010), Effects of long-term ethanol consumption on adhesion molecules in liver, Indian Journal of Experimental Biology, vol. 48, no. 4, pp. 394-401.

De Minicis, S. et al. (2007), Gene expression profiles during hepatic stellate cell activation in culture and in vivo, Gastroenterology, vol. 132, no. 5, pp. 1937-1946.

El-Rigal, N.S. et al. (2013), Oxidative Stress in Liver Diseases, JPCR, vol. 5, pp. 155-164. EPA, (2010), Toxicological review of Carbon Tetrachloride (CAS No. 56-23-5). EPA/635/R$08 / 005 \mathrm{~F}$ available

at: http://cfpub.epa.gov/ncea/iris/iris_documents/documents/toxreviews/0020tr.pdf (accessed on 24 October 2015).

Fathi, N.H. et al. (2002), Longitudinal measurement of methotrexate liver concentrations does not correlate with liver damage, clinical efficacy, or toxicity during a 3.5 year double blind study in rheumatoid arthritis, J Rheumatol, vol. 29, no. 10, pp. 2092-2098.

Faubion, W.A. and G.J. Gores GJ (1999), Death receptors in liver biology and pathobiology, Hepatology, vol. 29, no. 1, pp. 1-4.

Felser, A. et al. (2013), Mechanisms of hepatocellular toxicity associated with dronedarone-a comparison to amiodarone, Toxicological Sciences, vol. 131, no. 2, pp. 480-490.

Feng, Y. et al. (2011), Hepatoprotective effect and its possible mechanism of Coptidis rhizoma aqueous extract on carbon tetrachloride-induced chronic liver hepatotoxicity in rats, $J$ Ethnopharmacol, vol.138, no. 33, pp. 683-690.

Friedman, S.L (2010), Evolving challenges in hepatic fibrosis, Nat. Rev. Gastroenterol. Hepatol, vol. 7, no. 8, pp. 425-436.

Friedman, S.L. (2008), Mechanisms of Hepatic Fibrogenesis, Gastroenterology, vol. 134, no. 6, pp. $1655-1669$.

Friedman, S.L. (2004), Mechanisms of disease: Mechanisms of hepatic fibrosis and therapeutic implications, Nat Clin Pract Gastroenterol Hepatol, vol. 1, no. 2, pp. 98-105.

Friedman, S.L. (2002), Hepatic Fibrosis-Role of Hepatic Stellate Cell Activation, MedGenMed, vol. 4 , no. 3, pp. 27.

Friedman, S.L. (1999), Stellate cell activation in alcoholic fibrosis - an overview, Alcohol Clin Exp Res, vol. 23, no. 5, pp. 904-910. 
Fujiwara, N. and K. Kobayashi (2005), Macrophages in inflammation, Curr Drug Targets Inflamm Allergy, vol. 4, no. 3, pp. 281-286.

George, J. (2003), Ascorbic acid concentrations in dimethylnitrosamine-induced hepatic fibrosis in rats, Clin Chim Acta, vol. 335, no. 1-2, pp. 39-47.

George, J. et al. (2001), Dimethylnitrosamine-induced liver injury in rats: the early deposition of collagen, Toxicology, vol.156, n0. 2-3, pp. 129-138.

Golli-Bennour, E.E. et al. (2012), Cytotoxicity effects of amiodarone on cultured cells, Exp Toxicol Pathol, vol. 64, no. 5, pp. 425-430.

Gressner , A.M. et al. (2002), Roles of TGF- $\beta$ in hepatic fibrosis. Front Biosci, vol. 7, pp. 793807.

Guo, J. and S. L. Friedman (2010), Toll-like receptor 4 signaling in liver injury and hepatic fibrogenesis, Fibrogenesis Tissue Repair, vol. 3, p. 21.

Guo, J. and S. L. Friedman (2007), Hepatic fibrogenesis, Semin Liver Dis, vol. 27, no. 4, pp. 413426.

Hajovsky, H. et al. (2012), Metabolism and toxicity of thioacetamide and thioacetamide S-oxide in rat hepatocytes, Chem Res Toxicol, vol. 25, no. 9, pp. 1955-1963.

Hall, P.D. et al. (1991), Hepatotoxicity in a rat model caused by orally administered methotrexate, Hepatology, vol. 14, no. 5, pp. 906-910.

Hamdy, N. and E. El-Demerdash. (2012), New therapeutic aspect for carvedilol: antifibrotic effects of carvedilol in chronic carbon tetrachloride-induced liver damage, Toxicol Appl Pharmacol, vol. 261, no. 3, pp. 292-299.

Henderson, N.C. and J.P. Iredale (2007), Liver fibrosis: cellular mechanisms of progression and resolution, Clin Sci (Lond), vol. 112, no. 5, pp. 265-280.

Huang, L. et al. (2008), Genes related to apoptosis predict necrosis of the liver as a phenotype observed in rats exposed to a compendium of hepatotoxicants, BMC Genomics, vol. 16, no. 9, pp. 288.

Hytiroglou ,P. et al. (2004), The canals of hering might represent a target of methotrexate hepatic toxicity, Am J Clin Pathol, vol. 121, no. 3, pp. 324-329.

Ide, M. et al. (2005), Effects of gadolinium chloride $(\mathrm{GdCl}(3))$ on the appearance of macrophage populations and fibrogenesis in thioacetamide-induced rat hepatic lesions, J Comp Pathol, vol. 133 , no. 2-3, pp. 92-102.

Ide, M. et al. (2003), Emergence of different macrophage populations in hepatic fibrosis following thioacetamide-induced acute hepatocyte injury in rats, J Comp Patho, vol. 128, no. 1, pp. 41-51.

Iredale, J.P. (2007), Models of liver fibrosis: exploring the dynamic nature of inflammation and repair in a solid organ, J Clin Invest, vol. 117, no. 3, pp. 539-548.

Isomoto, S. et al. (2004), Antiarrhythmic amiodarone mediates apoptotic cell death of hepg2 hepatoblastoma cells through the mitochondrial pathway, Acta medica Nagasakiensia, vol. 49, no. 1-2, pp. 13-17.

Jaeschke, H. et al. (2013), Models of drug-induced liver injury for evaluation of phytotherapeutics and other natural products, Food and Chemical Toxicology, vol. 55, pp. 279-289.

Jaeschke, H. (2011), Reactive oxygen and mechanisms of inflammatory liver injury: Present concepts, J Gastroenterol Hepatol. vol. 26, suppl. 1, pp. 173-179. 
Jaeschke, H. (2002a), Inflammation in response to hepatocellular apoptosis, Hepatology, vol. 35, no. 4, pp. 964-966.

Jaeschke, H. et al. (2002b), Mechanisms of hepatotoxicity, Toxicological Sciences, vol. 65, no. 2, pp. 166-176.

Jang, J.H. et al. (2008), Reevaluation of experimental model of hepatic fibrosis induced by hepatotoxic drugs: an easy, applicable, and reproducible model, Transplantation Proceedings, vol. 40, no. 8, pp. 2700-2703.

Ju, H.K. et al. (2013), Investigation of metabolite alteration in dimethylnitrosamine-induced liver fibrosis by GC-MS, Bioanalysis, vol. 5, no. 1, pp. 41-51.

Jung, S.A. et al. (2000), Experimental model of hepatic fibrosis following repeated periportal necrosis induced by allylalcohol, Scand J Gastroenterol, vol. 35, no. 9, pp. 969-975.

Kaimori, A. et al. (2007), Transforming growth factor-beta1 induces an epithelial-tomesenchymal transition state in mouse hepatocytes in vitro, J Biol Chem, vol. 282, no. 30, pp. 22089-22101.

Kamimura, S. and H. Tsukamoto (1995), Cytokine gene expression by Kupffer cells in experimental alcoholic liver disease, Hepatology, vol. 22, no. 4, pp. 1304-1309.

Kang, J.S. (2008), Role of CYP2E1 in thioacetamide-induced mouse hepatotoxicity, Toxicol Appl Pharmacol, vol. 228, no. 3, pp. 295-300.

Kehrer, J.P. and S. Biswal (2000), The Molecular Effects of Acrolein, Toxicol. Sciences, vol. 57, no. 1, pp. 6-15.

Kershenobich Stalnikowitz, D. and A.B. Weisssbrod (2003), Liver Fibrosis and Inflammation. A Review, Annals of Hepatology, vol. 2, no. 4, pp.159-163.

Kicker, J.S. et al. (2012), Hepatotoxicity after continuous amiodarone infusion in a postoperative cardiac infant, J Pediatr Pharmacol Ther, vol. 17, no. 2, pp. 189-195.

Kim, J.H. et al. (2013), Chronic vitamin C insufficiency aggravated thioacetamide-induced liver fibrosis in gulo-knockout mice, Free Radic Biol Med, vol. 67, pp. 81-90.

Kirkham, P. (2007), Oxidative stress and macrophage function: a failure to resolve the inflammatory response, Biochem Soc Trans, vol. 35, no. 2, pp. 284-287.

Kisseleva T and Brenner DA, (2008), Mechanisms of Fibrogenesis, Exp Biol Med, vol. 233, no. 2, pp. 109-122.

Kisseleva, T. and Brenner, D.A. (2007), Role of hepatic stellate cells in fibrogenesis and the reversal of fibrosis, Journal of Gastroenterology and Hepatology, vol. 22, Suppl. 1; pp. S73-S78.

Knockaert, L. et al. (2012), Carbon tetrachloride-mediated lipid peroxidation induces early mitochondrial alterations in mouse liver, Lab Invest, vol. 92, no. 3, pp. 396-410.

Kolios, G., V. Valatas and E. Kouroumalis (2006), Role of Kupffer Cells in the Pathogenesis of Liver Disease, World J.Gastroenterol, vol. 12, no. 46, pp. 7413-7420.

Kresse, M. et al. (2005), Kupffer cell-expressed membrane-bound TNF mediates melphalan hepatotoxicity via activation of both TNF receptors, J. Immunol, vol. 175, no. 6, pp. 40764083.

LeCluyse, E.L. et al. (2012), Organotypic liver culture models: meeting current challenges in toxicity testing, Crit Rev Toxicol, vol. 42, no. 6, 501-548. 
Ledda-Columbano, G.M. et al. (1991), Induction of two different modes of cell death, apoptosis and necrosis, in rat liver after a single dose of thioacetamide, Am J Pathol, vol. 139, no. 5, pp. 1099-1109.

Lee Kwang-Jong et al. (2004), Induction of molecular chaperones in carbon tetrachloride-treated rat liver: implications in protection against liver damage, Cell Stress Chaperones, vol. 9, no. 1, pp. 58-68.

Lee, U.E. and S.L. Friedman (2011), Mechanisms of Hepatic Fibrogenesis, Best Pract Res Clin Gastroenterol, vol. 25, no. 2, pp. 195-206.

Lee William M. (2003), Drug- induced hepatotoxicity, $N$ Engl J Med, vol. 349, no. 5, pp. 474485.

Leung, T.M. et al. (2008), Endothelial nitric oxide synthase is a critical factor in experimental liver fibrosis, Int J Exp Pathol, vol. 89, no. 4, pp. 241-250.

Levine, P.H. et al. (2003), Stellate-cell lipidosis in liver biopsy specimens. Recognition and significance, Am J Clin Pathol, vol. 119, no. 2, pp. 254-258.

Li, Jing-Ting et al. (2008), Molecular mechanism of hepatic stellate cell activation and antifibrotic therapeutic strategies, J Gastroenterol, vol. 43, no. 6, pp. 419-428.

$\mathrm{Li}$, Li et al. (2012), Establishment of a standardized liver fibrosis model with different pathological stages in rats, Gastroenterol Res Pract; vol. 2012, Article ID 560345.

Li Xiaowei et al. (2014), NMR-based metabonomic and quantitative real-time PCR in the profiling of metabolic changes in carbon tetrachloride-induced rat liver injury, $J$ Pharm Biomed Anal, vol. 89, pp. 42-49.

Liebler, D.C. (2008), Protein Damage by Reactive Electrophiles: Targets and Consequences, Chem Res Toxicol, vol. 21, no. 1, pp. 117-128.

Lindsay, K. et al. (2009), Liver fibrosis in patients with psoriasis and psoriatic arthritis on longterm, high cumulative dose methotrexate therapy, Rheumatology, vol. 48: no. 5, pp. 569572.

Liu, Xingjun et al. (2006), Therapeutic strategies against TGF-beta signaling pathway in hepatic fibrosis. Liver Int, vol.26, no.1, pp. 8-22.

Liu Youhua (2011), Cellular and molecular mechanisms of renal fibrosis, Nat. Rev.nephrol, vol 7, no. 12 , pp. 684-696.

López-Novoa, J.M. and M.A. Nieto (2009), Inflammation and EMT: an alliance towards organ fibrosis and cancer progression, EMBO Mol Med, vol. 1. no. 6-7, pp. 303-314.

Low, T.Y. et al. (2004), A proteomic analysis of thioacetamide-induced hepatotoxicity and cirrhosis in rat livers, Proteomics, vol. 4, no. 12, pp. 3960-3974.

Lu, J. et al. (2013), Tumor necrosis factor-alpha potentiates the cytotoxicity of amiodarone in Hepa1c1c7 cells: roles of caspase activation and oxidative stress, Toxicological Sciences, vol. 131, no. 1, pp.164-178.

Luckey, S.W., and D.R. Petersen (2001), Activation of Kupffer cells during the course of carbon tetrachloride-induced liver injury and fibrosis in rats, Exp Mol Pathol, vol. 71, no. 3 , pp. 226-240.

Luster, M.I. et al. (2001), Role of inflammation in chemical-induced hepatotoxicity, Toxicol Lett, vol. 120 , no. $1-3$, pp. 317-321. 
Luster, M.I. et al. (2000), Immunotoxicology: role of inflammation in chemical-induced hepatotoxicity, Int J Immunopharmacol, vol. 22, no. 12, pp. 1143-1147.

Lv, L. et al. (2012), Protective effects of lotus (Nelumbo nucifera Gaertn) germ oil against carbon tetrachloride-induced injury in mice and cultured PC-12 cells, Food Chem Toxicol, vol. 50, no. 5, pp. 1447-1453.

Malhi, H. et al. (2010), Hepatocyte death: a clear and present danger, Physiol Rev, vol. 90, no. 3, pp. 1165-1194.

Manibusan, M.K., M. Odin and D.A. Eastmond (2007), Postulated carbon tetrachloride mode of action: a review, J Environ Sci Health C Environ Carcinog Ecotoxicol Rev, vol. 25, no. 3, pp.185-209.

Marra, F. (2002), Chemokines in liver inflammation and fibrosis, Front Biosci, vol. 7, pp. 18991914.

Masuda, Y. (2006), [Learning toxicology from carbon tetrachloride-induced hepatotoxicity], Yakugaku Zasshi, vol. 126, no. 10, pp. 885-899.

Matsuoka, M. and H. Tsukamoto, (1990), Stimulation of hepatic lipocyte collagen production by Kupffer cell-derived transforming growth factor beta: implication for a pathogenetic role in alcoholic liver fibrogenesis, Hepatology, vol. 11, no. 4, pp. 599-605.

Mehta N and Ozick LA, (2014), Drug-Induced Hepatotoxicity. Medscape E-Medicine http://emedicine.medscape.com/article/169814-overview (accessed on 12 December 2014).

Milani, S. et al. (1994), Differential expression of matrix-metalloproteinase-1 and -2 genes in normal and fibrotic human liver, Am J Pathol, vol. 144, no. 3, pp. 528-537.

Mohammad, M.K. et al. (2012), Acrolein cytotoxicity in hepatocytes involves endoplasmic reticulum stress, mitochondrial dysfunction and oxidative stress, Toxicol Appl Pharmacol, vol. 265, no. 1, pp. 73-82.

Morio, L.A. et al. (2001), Distinct roles of tumor necrosis factor-alpha and nitric oxide in acute liver injury induced by carbon tetrachloride in mice, Toxicol Appl Pharmacol, vol. 172, no. 1, pp. 44-51.

Nafees ,S. et al. (2013), Carvacrol ameliorates thioacetamide-induced hepatotoxicity by abrogation of oxidative stress, inflammation, and apoptosis in liver of Wistar rats, Hum Exp Toxicol, vol. 32, no.12, pp. 1292-1304.

Nagano, K. et al. (2007), Inhalation carcinogenicity and chronic toxicity of carbon tetrachloride in rats and mice, Inhal Toxicol, vol 19, no. 13, pp. 1089-1103.

Nakamura, I. et al. (2014), Brivanib attenuates hepatic fibrosis in vivo and stellate cell activation in vitro by inhibition of FGF, VEGF and PDGF signaling, PLoS One, vol. 9, no. 4, e92273.

Nan, Y.M. et al. (2013), Activation of peroxisome proliferator activated receptor alpha ameliorates ethanol mediated liver fibrosis in mice, Lipids Health Dis, vol. 12, p.11.

Nasser .M. et al. (2013), Hyperacute drug-induced hepatitis with intravenous amiodarone: case report and review of the literature, Drug Healthc Patient Saf, vol. 5, pp. 191-198.

Natajaran, S.K. et al. (2006), Oxidative stress in the development of liver cirrhosis: a comparison of two different experimental models, J Gastroenterol Hepatol, vol. 21, no. 6, pp. 947-957.

Natsume, M et a.1, (1999), Attenuated liver fibrosis and depressed serum albumin levels in carbon tetrachloride-treated IL-6-deficient mice, J Leukoc Biol, vol. 66, no. 4, pp. 601-608. 
Neubauer K. et al. (1998), Sinusoidal intercellular adhesion molecule-1 up-regulation precedes the accumulation of leukocyte function antigen-1-positive cells and tissue necrosis in a model of carbontetrachloride-induced acute rat liver injury, Lab Invest, vol.78, no. 2, pp. 185-194.

Nissar, A.U. et al. (2013), Effect of N-acetyl cysteine (NAC), an organosulfur compound from Allium plants, on experimentally induced hepatic prefibrogenic events in Wistar rat, Phytomedicine, vol. 20, no. 10, pp. 828-833.

Nollevaux, M.C. et al. (2006), Hypervitaminosis A-induced liver fibrosis: stellate cell activation and daily dose consumption, Liver Int, vol. 26, no. 2, pp. 182-186.

Orrenius, S., P. Nicotera and B. Zhivotovsky (2011), Cell death mechanisms and their implications in toxicology, Toxicol. Sci, vol. 119, no. 1, pp. 3-19.

Paik, Y.H. et al. (2011), The nicotinamide adenine dinucleotide phosphate oxidase (NOX) homologues NOX1 and NOX2/gp91(phox) mediate hepatic fibrosis in mice, Hepatology, vol. 53 , no. 5 , pp. $1730-1741$.

Pandey, G. et al. (2011), Experimental hepatotoxicity produced by ethinyl estradiol, Toxicol Int, vol. 18, no. 2, pp. 160-162.

Pandey, G. et al. (2010), Hepatic cell injury by ethinyl estradiol estrogen, IJPSR, vol. 1, no. 1, pp. 49-53.

Park, D.H. et al. (2004), Chronic hepatotoxicity of carbon tetrachloride in hsp-70 knock-out mice, Exp Anim, vol. 53, no. 1, pp. 27-30.

Parmentier, C. et al. (2013), Transcriptomic hepatotoxicity signature of chlorpromazine after short- and long-term exposure in primary human sandwich cultures, Drug Metab Dispos, vol. 41, no. 10, pp. 1835-1842.

Parola, M. and G. Robino (2001), Oxidative stress-related molecules and liver fibrosis. J Hepatol, vol. 35, no. 2, pp. 297-306.

Parsons, C.J., M.Takashima and R.A. Rippe (2007), Molecular mechanisms of hepatic fibrogenesis. J Gastroenterol Hepatol, vol. 22, Suppl.1, pp. S79-S84.

Pellicoro, A. et al. (2014), Liver fibrosis and repair: immune regulation of wound healing in a solid organ, Nat Rev Immunol, vol. 14, no. 3, pp. 181-194.

Poli, G. (2000), Pathogenesis of liver fibrosis: role of oxidative stress, Mol Aspects Med, vol. 21, no. 3 , pp. $49-98$.

Poynard, T., P. Bedossa and P. Opolon (1997), Natural history of liver fibrosis progression in patients with chronic hepatitis C. The OBSVIRC, METAVIR, CLINIVIR, and DOSVIRC groups, Lancet, vol. 349, no. 9055, pp. 825-832.

Purohit, V. and D.A. Brenner (2006), Mechanisms of alcohol-induced hepatic fibrosis: A summary of the Ron Thurman symposium, Hepatology, vol. 43, no. 4, pp. 872-878.

Qi Z et al. (1999), Blockade of type beta transforming growth factor signaling prevents liver fibrosis and dysfunction in the rat, Proc Natl Acad Sci USA, vol. 96, no. 5, pp. 2345-2349.

Radzikowska, E. et al. (2012), Estrogen-induced hepatotoxicity in rats, Journal of Pre-Clinical and Clinical Research, vol. 6, no. 1, pp. 10-13.

Ramachandran, R. and S. Kakar (2009), Histological patterns in drug-induced liver disease, J Clin Pathol, vol. 62, no. 6, pp. 481-492.

Recknagel, R.O. (1976), Carbon tetrachloride hepatotoxicity, Pharmacol Rev, vol. 19, no. 2, pp. 145-208. 
Reuter, S. et al. (2010), Oxidative stress, inflammation, and cancer: how are they linked? Free Radic Biol Med, vol. 49, no. 11, pp. 1603-1616.

Roberts, R.A. et al. (2007), Role of the Kupffer cell in mediating hepatic toxicity and carcinogenesis, Toxicol Sci, vol. 96, no. 1, pp. 2-15.

Rockey, D.C. and S.L. Friedman (2006), Hepatic fibrosis and cirrhosis, Zakim and Boyer's Hepatology, 5th edition, section 1, chapter 6, pp. 87-109.

Rockey, D.C. et al. (1992), Rat hepatic lipocytes express smooth muscle actin upon activation in vivo and in culture, J Submicrosc Cytol Pathol, vol. 24, no. 2, pp. 193-203.

Roth, S., K. Michel and A.M. Gressner (1998), (Latent) transforming growth factor beta in liver parenchymal cells, its injury-dependent release, and paracrine effects on rat HSCs, Hepatology, vol. 27, no. 4, pp. 1003-1012.

Russmann, S., G.A. Kullak-Ublick and I. Grattagliano (2009), Current concepts of mechanisms in drug-induced hepatotoxicity, Curr Med Chem, vol. 16, no. 23, pp. 3041-3053.

Safadi, R. and S.L. Friedman (2002), Hepatic fibrosis--role of hepatic stellate cell activation, MedGenMed, vol 4, no. 3, p. 27.

Sánchez-Valle, V. et al. (2012), Role of oxidative stress and molecular changes in liver fibrosis: a review, Curr Med Chem, vol. 19, no. 28, pp. 4850-4860.

Sarma, D. et al. (2012), Covalent modification of lipids and proteins in rat hepatocytes and in vitro by thioacetamide metabolites, Chem Res Toxicol, vol. 25, no. 9, pp. 1868-1877.

Schümann, J. et al. (2000), Importance of Kupffer cells for T-cell-dependent liver injury in mice, Am. J. Pathol, vol. 157, no, 5, pp. 1671-1683.

Schwab, C.E. and H. Tuschl (2003), In vitro studies on the toxicity of isoniazid in different cell lines, Hum Exp Toxicol, vol. 22, no. 11, pp. 607-615.

Schwend, T. et al. (2008), Alkylation of adenosine deaminase and thioredoxin by acrylamide in human cell cultures, $Z$ Naturforsch, vol. 64, no. 5-6, pp. 447-453.

Shirai, M. et al. (2013), Thioacetamide-induced hepatocellular necrosis is attenuated in dietinduced obese mice, J Toxicol Pathol, vol. 26, no. 2, pp. 175-186.

Siegmund, S.V. et al. (2005), Molecular mechanisms of alcohol-induced hepatic fibrosis, Dig Dis, vol. 23, no. 3-4, pp. 264-274.

Simeonova, P.P. et al. (2001), The role of tumor necrosis factor-alpha in liver toxicity, inflammation, and fibrosis induced by carbon tetrachloride, Toxicol Appl Pharmacol, vol. 177, no. 2, pp. 112-120.

Singh, M. et al. (2010), Studies on toxicity of antitubercular drugs namely isoniazid, rifampicin, and pyrazinamide in an in vitro model of HepG2 cell line, Med. Chem. Res, vol. 20, no. 9, pp. 1611-1615.

Sivakumar, P. and A.M. Das (2008), Fibrosis, chronic inflammation and new pathways for drug discovery, Inflamm Res, vol. 57, no. 9, pp. 410-418.

Soldatow, V.Y. et al. (2013), In vitro models for liver toxicity testing, Toxicol Res, vol. 2, no.1, pp. 23-39.

Son G. et al. (2009), Inhibition of phosphatidylinositol 3-kinase signaling in hepatic stellate cells blocks the progression of hepatic fibrosis, Hepatology, vol. 50, no. 5, pp. 1512-1523.

Staňková, P. et al. (2010), The toxic effect of thioacetamide on rat liver in vitro, Toxicol In Vitro, vol. 24, no. 8, pp. 2097-2103. 
Sun, F. et al. (2000), Evaluation of oxidative stress based on lipid hydroperoxide, vitamin C and vitamin E during apoptosis and necrosis caused by thioacetamide in rat liver, Biochim Biophys Acta, vol. 1500, no. 2, pp. 181-185.

Takehara, T. et al. (2004), Hepatocyte-specific disruption of Bcl-xL leads to continuous hepatocyte apoptosis and liver fibrotic responses, Gastroenterology, vol. 127, no. 4, pp. 1189-1197.

Tan, A.B. et al. (2013), Cellular re- and de-programming by microenvironmental memory: why short TGF- $\beta 1$ pulses can have long effects, Fibrogenesis Tissue Repair, vol. 6, no. 1, p. 12.

Tanel, A. et al. (2007), Activation of the death receptor pathway of apoptosis by the aldehyde Acrolein, Free Radic Biol Med, vol. 42, no. 6, pp. 798-810.

Tang, L.X. et al. (2012), Asiatic acid inhibits liver fibrosis by blocking TGF- $\beta$ /Smad signaling in vivo and in vitro, PLoS One, vol. 7, no. 2, e31350.

Thompson, K.J., I.H. McKillop and L.W. Schrum (2011), Targeting collagen expression in alcoholic liver disease, World J Gastroenterol, vol. 17, no. 20, pp. 2473-2481.

Thompson, C.A. and P.C. Burcham (2008), Protein alkylation, transcriptional responses and cytochrome c release during Acrolein toxicity in A549 cells: influence of nucleophilic culture media constituents, Toxicol In Vitro, vol. 22, no. 4, pp. 844-853.

Tipoe, G.L. et al. (2006), Inhibitors of inducible nitric oxide (NO) synthase are more effective than an NO donor in reducing carbon-tetrachloride induced acute liver injury, Histol Histopathol, vol. 21, no. 11, pp. 1157-1165.

Tostmann, A et. al. (2008), Isoniazid and its toxic metabolite hydrazine induce in vitro pyrazinamide toxicity, Int J Antimicrob Agents, vol. 3, no. 6, pp. 577-580.

Tsukamoto, H., M. Matsuoka and S.W. French (1990), Experimental models of hepatic fibrosis: a review, Semin Liver Dis, vol. 10, no. 1, pp. 56-65.

Tukov, F.F. et al. (2006), Modeling inflammation-drug interactions in vitro: a rat Kupffer cellhepatocyte co-culture system, Toxicol In Vitro, vol. 20, no. 8, pp. 1488-1499.

Usunomena, U. et al. (2012), N-nitrosodimethylamine (NDMA), liver function enzymes, renal function parameters and oxidative stress parameters: a review, British Journal of Pharmacology and Toxicology, vol. 3, no. 4, pp. 165-176.

Wang, J.H. et al. (2006), Role of ethanol in the regulation of hepatic stellate cell function, World $J$ Gastroenterol, vol. 12, no. 43, pp. 6926-6932.

Watanabe, A. et al. (2007), Apoptotic hepatocyte DNA inhibits hepatic stellate cell chemotaxis via toll-like receptor 9, Hepatology, vol. 46, no. 6, pp. 1509-1518.

Waters, N.J. et al. (2005), Metabonomic deconvolution of embedded toxicity: application to thioacetamide hepato- and nephrotoxicity, Chem Res Toxicol, vol.18, no. 4, pp. 639-654.

Weber, L.W., M. Boll and A. Stampfl (2003), Hepatotoxicity and mechanism of action of haloalkanes: carbon tetrachloride as a toxicological model, Crit Rev Toxicol, vol. 33, no. 2, pp. 105-136.

Weber, S. et al. (2010), Liver fibrosis: from animal models to mapping of human risk variants, Best Practice \& Research Clinical Gastroenterology, vol. 24, no. 5, pp. 635-646.

Wen, B. and M. Zhou (2009), Metabolic activation of the phenothiazine antipsychotics chlorpromazine and thioridazine to electrophilic iminoquinone species in human liver microsomes and recombinant P450s, Chem Biol Interact, vol. 181, no. 2, pp. 220-226. 
Williams, E.J. et al. (2000), Increased expression of connective tissue growth factor in fibrotic human liver and in activated hepatic stellate cells, J Hepatol, vol. 32, no. 5, pp. 754-761.

Winwood, P.J., and M.J. Arthur (1993), Kupffer cells: their activation and role in animal models of liver injury and human liver disease, Semin Liver Dis, vol. 13, no. 1, pp. 50-59.

Wynn, T.A. (2008), cellular and molecular mechanisms of fibrosis, J Pathol, vol. 214, no. 2, pp. 199-210.

Yamada, T. et al. (2013), A category approach to predicting the repeated-dose hepatotoxicity of allyl esters, Regulatory Toxicology and Pharmacology, vol. 65, no. 2, pp. 189-195.

Yin, C. et al. (2013), Hepatic stellate cells in liver development, regeneration, and cancer, J Clin Invest, vol. 123, no. 5, pp. 1902-1910.

Zhu, W. and P.C. Fung (2000), The roles played by crucial free radicals like lipid free radicals, nitric oxide, and enzymes NOS and NADPH in $\mathrm{CCl}(4)$-induced acute liver injury of mice, Free Radic Biol Med, vol. 29, no. 9, pp. 870-880. 